\title{
Problem of Choice
}

\section{Land in Papua New Guinea's Future}

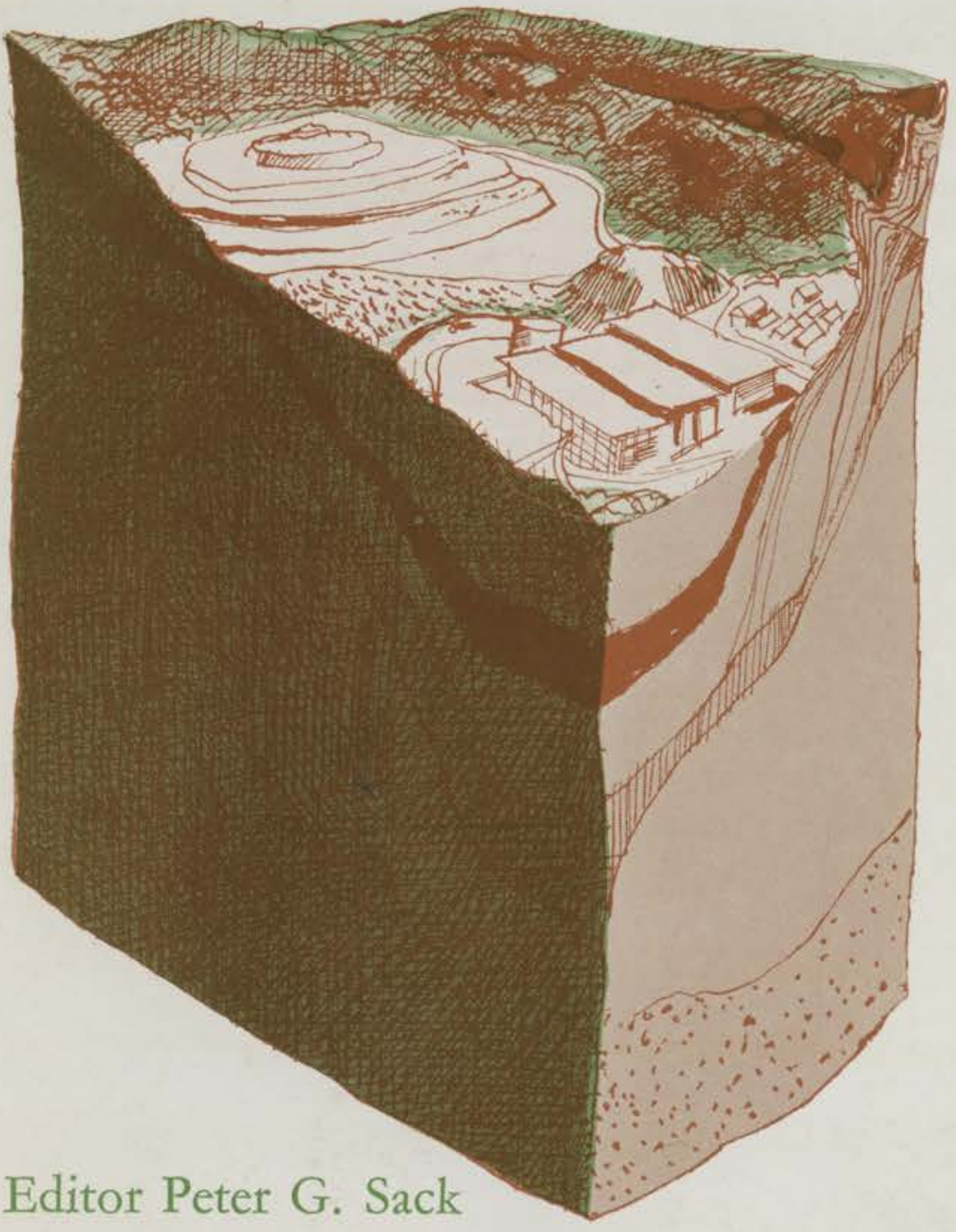


For the peoples of Papua New Guinea land is overwhelmingly important, not only as the sole means of life but also for what it means in their culture. It is inalienable; it came to them from all their forebears, and it will belong to all their descendants. Its emotional and spiritual significance evokes from them a religio-mystical response completely alien to the Western attitude that land is just another commodity.

Yet, for a developing nation, land is also a commodity - to be bought and sold for large-scale agriculture, to be mined, to be used for commerce and agriculture, schools and cities. Thus there is an inherent conflict between traditional and potential uses reflecting a profound conflict of values and attitudes.

As Papua New Guinea approaches independence, no problem is of greater importance than the role of land, for no other issue is potentially so violently divisive. Is it to be a national estate? Is it to be owned and used individually, co-operatively, corporately? What will be the impact on the whole social fabric of the country and the lives of its people?

In essays expressing every shade of opinion from expatriate detachment or involved commitment and conviction to indigenous bewilderment, rage, frustration, or sense of betrayal, the authors in this book examine some aspects of these extremely complex problems.

For the future unity and security of the country the answer is crucial. It is one that the Papua New Guineans alone must make. But there is no easy answer, no simple solution, to their Problem of Choice. 
This book was published by ANU Press between 1965-1991. This republication is part of the digitisation project being carried out by Scholarly Information Services/Library and ANU Press.

This project aims to make past scholarly works published by The Australian National University available to a global audience under its open-access policy. 
Problem of choice 


\section{Problem of choice}

Land in Papua New Guinea's future

Peter G. Sack Editor

AUSTRALIAN NATIONAL UNIVERSITY PRESS CANBERRA 1974 
First published in Australia 1974

Printed in Australia for the Australian National University Press, Canberra

North, South, and Central America:

International Scholarly Book Services, Inc., Portland, Oregon

Southeast Asia: Angus \& Robertson

(S.E. Asia) Pty Itd, Singapore

Japan: United Publishers Services Ltd, Tokyo

(C) Peter G, Sack 1974

This book is copyright. Apart from any fair dealing for the purposes of private study, research, criticism, or review, as permitted under the Copyright Act, no part may be reproduced by any process without written permission. Inquiries should be made to the publisher.

ISBN 0708107095

Library of Congress Catalog Card no. 73-90282 


\section{Foreword}

Peter Sack, the author of the instructive and very readable book, Land Between Two Laws, has the knack for picking the apt title. Problem of Cboice; it could not have been put more appropriately. As Peter Sack says in his preface, the land problems facing Papua New Guinea are primarily problems of political choice.

What choice should we make? Although the contributions here are by people of diverse backgrounds, what emerges from a variety of approaches is, by and large, a plea for fundamental land reform; fundamental in the sense of remaining in touch with home-grown structures. There is no call for a complete reversion to customary institutions but there is a clear warning that it would be foolhardy to nourish imported concepts without carefully scrutinising their relevance to Papua New Guinea.

The Commission of Inquiry, instituted by my Government to have a fresh look at Papua New Guinea's land problems, will have made its final findings by the time this volume is published. After many months and hundreds of thousands of words from many, many people, the 'problem of choice' is being tackled.

M. T. Somare

Chief Minister of Papua New Guinea

Port Moresby

7 September 1973 


\section{Preface}

Although this volume developed as a reaction to the 1971 land bills mentioned in many contributions, its aim is neither to criticise these bills nor to present an alternative to them. Instead of arguing the case for or against any particular solution, it wants to show that the land problems facing Papua New Guinea are primarily problems of political choice. It does not attempt to do this by discussing the range of problems and possible solutions in a detached and systematic way: this is an unashamedly subjective and sometimes passionate book. But it brings together the personal views of very different people-missionaries, bankers, doctors, politicians, students, lawyers, economists and public servants-most of whom are participants rather than observers.

By recording their views, including most of the individual, professional, political, or cultural peculiarities in approach and style, this book first of all tries to capture the spirit of this transitional period between colonialism and independence, when old problems appear in a new light and new problems begin to cast their shadows, when the old white administrators are not yet quite 'out' and the new black politicians are not yet quite 'in', when important decisions are imminent but have not yet been made, when the wheels of history turn with dazzling speed but history itself is somehow suspended, when idealism and pragmatism, cynicism and naiveté, radicalism and conservatism mingle in the most amazing way, and when almost everything seems possible and almost nothing real.

Nevertheless, it is hoped that this kaleidoscope of views will prove to be more than just a historical document, overtaken by developments before it sees the light of day. Despite and perhaps also because of its many gaps and limitations, it may help the people of Papua New Guinea to get a better understanding of what is involved in the battle in which they are engaged. The choice of weapons is theirs; and the act of choice by the people is probably more important than the objective suitability of the type of weapon chosen. This does not mean that Papua New Guinea should reject all foreign advice or aid, or that it should rush into decisions without carefully considering the consequences. But it would be even more dangerous to see all problems 
and possible solutions in purely technical and financial terms and to neglect the crucial human factor. There will be many difficult technical and financial problems, but they are not decisive, so that an objective factual analysis, no matter how honest and sophisticated, is likely to hide the real problems instead of explaining them.

What all this amounts to, and what this volume tries to convey, is simply this: independence is a state of mind and not a result of constitutional developments or economic self-sufficiency; in order to have a future, one must believe in it; and one can only do this if one sees the people behind the facts and figures. The future of Papua New Guinea is not a bundle of abstract problems, it is first and foremost the people themselves, the people and their land.

Peter G. Sack

Canberra

August 1973 


\section{Contents}

Foreword

Preface

Note on contributors

$x i$

1 The problem of choice P. G. Sack 1

2 The historical dimension $P$. Chatterton 8

3 The limits of choice E. J. Clay and M. C. Evans 16

4 The psychological dimension B. G. Burton-Bradley 32

5 The price of progress N. E. Olewale 40

6 The cultural squeeze D. M. Fenbury 49

7 The Kenyan model T. Bredmeyer 62

8 The Niue alternative R. G. Crocombe 75

9 Customising the law C. J. Lyncb 87

10 Technical law and the outside expert $\quad$ D. J. Whalan 97

11 A banker's gamble R. J. Gunton 107

12 Destruction or adaptation C. W. Kimmorley 115

13 Cash-cropping and population pressure T. M. Kambipi 126

14 Law enforcement or land reforms I. Nilles 134

15 'They fight for fun' M. B. Orken 141

16 Politics and societal trauma W. A. Standish 151

17 Indefeasibility and justice W. Kaputin 159

18 Alienation and identity P. G. Sack 164

19 Urban expansion and customary land N. D. Oram 170

20 Mining bitterness J. Dove, T. Miriung, M. Togolo 181

21 Taming the dragon J. Momis 190

22 The triumph of colonialism P. G. Sack 200

References 209

Index $\quad 213$ 


\section{Note on contributors}

T. Bredmeyer has been working for the Department of Law in Papua New Guinea since 1964; he is now Acting Deputy Crown Solicitor in Rabaul.

B. G. Burton-Bradley came to Papua New Guinea in 1959. He is Chief of the Division of Mental Health in the Department of Public Health and Associate Professor of Psychiatry at the University of Papua New Guinea.

P. Chatterton has been living in Papua New Guinea since 1924. He retired from the service of the London Missionary Society in 1964. He was a member of the First and Second Houses of Assembly.

E. J. Clay is Lecturer in Economics at the University of Papua New Guinea.

R. G. Crocombe is Professor of Pacific Studies at the University of the South Pacific.

J. Dove is an Economics student at the University of Papua New Guinea.

M. C. Evans is Lecturer in Economics at the University of Papua New Guinea.

D. M. Fenbury came to Papua New Guinea as a cadet patrol officer in 1937. Before his retirement in 1973 he was Head of the Department of Social Development and Home Affairs.

R. J. Gunton is the Projects Manager of the Papua and New Guinca Development Bank on leave from the Department of Economics, University of Queensland.

T. M. Kambipi is Member for Kompiam-Baiyer in the House of Assembly. 
W. Kaputin graduated in Law from the University of Papua New Guinea in 1972; he is completing his practical legal training.

C. W. Kimmorley came to Papua New Guinea as a soldier in 1942. He joined the Administration in 1946 and the Land Titles Commission in 1960 . He is now Senior Commissioner.

C. J. Lynch has been concerned with the laws of Papua New Guinea since 1949; he is now the Legislative Draftsman.

T. Miriung graduated in Law from the University of Papua New Guinea in 1973; he is completing his practical legal training.

Father J. Momis, MHA (Bougainville Regional) is Deputy Chairman of the Constitutional Planning Committee.

Father J. Nilles has been a resident of the Chimbu District since 1937. He was a member of the District Advisory Council as well as the Local Government Council and also represented the District in the Second House of Assembly.

N. E. Olewale, MHA (South Fly Open) is Minister for Education.

N. O. Oram is a Fellow of the University of Papua New Guinea and a Port Moresby City Councillor.

M. B. Orken, Senior Land Titles Commissioner, served in Papua New Guinea during the Second World War. He became a field officer of the Administration in 1949 and joined the Native Land Commission in 1959.

P. G. Sack is Research Fellow in Papua New Guinea Law at the Australian National University.

W. A. Standish is Lecturer in Political Studies at the University of Papua New Guinea. 
M. Togolo is an Economics student at the University of Papua New Guinea.

D. G. Whalan is Professor of Law at the Australian National University. 


\section{The problem of choice \\ P. G. Sack}

In March 1971 the Administration of Papua New Guinea introduced a series of four land bills in the House of Assembly. Although the bills contained significant legal changes, they were not revolutionary but firmly based on an established policy of individualising customary tenure and of registering the resulting titles. In an official statement to the House in March 1970, foreshadowing the proposed legislation, the Director for Lands, Surveys and Mines, Don Grove, justified this policy roughly as follows: traditional land tenure must be changed because it is holding up development; it dampens the individual initiative of traditional owners, leads to disputes between them and makes them reluctant to transfer surplus land to those willing and able to use it effectively (House of Assembly Debates, 1970 vol. 2: 2407).

The House gave no indication that it disagreed with these views. Yet in June 1971, after a short debate, mounting opposition forced the Administration to withdraw the bills. Announcing the withdrawal, the Director for Lands, Surveys and Mines claimed that this opposition was merely due to the fact that the bills had not been properly understood (ibid.: 4413). Though correct, this explanation is not sufficient. Inability to appreciate the legal complexities of bills had not prevented the House from supporting equally technical legislation in the past. Indeed Koriam Urekit, the Member for Kandrian/Pomio, one of the few speakers to support the land bills, openly admitted that he did so without being able to read them (ibid.: 1970: 4325). An unnamed expert, quoted in the Post Courier (21 June 1971), suggested a different explanation. According to him the attitude shown in the House was typical for underdeveloped countries: 'Their leaders do not appear to like making decisions, the big decisions that really count.' Again, this interpretation points to what may become a serious danger, but it does injustice to an event which marks a turning-point in Papua New Guinea's history: at least as far as land is concerned the future of the country began in June 1971.

A year earlier the proposed legislation had been seen against the 
background of the existing colonial land laws, that is, the past. It was welcomed, though without great enthusiasm, because it was, in this light, a major improvement. In June 1971 the perspective was different. The politicians sensed that they were being asked to choose the system of land laws most suitable for their country in the future. The bills were now seen as an alternative to the peoples' own traditional customs, instead of the existing colonial laws which so far had had little influence on their lives. The politicians began to doubt whether this was an appropriate time to enact a new and, from this point of view, revolutionary charter of the land, and whether it was not for the people to frame this charter rather than an outgoing colonial administration, however well intentioned. They became aware that these land bills had a direct bearing on the kind of country Papua New Guinea was to become-and they started to question the underlying policies: was the economic development for which the bills were designed really the goal they wanted to achieve? Yet the basic reason for the opposition had little to do with the contents of the bills. The House of Assembly was just no longer prepared to accept any new land laws as a gift from the Administration; it felt that the people of Papua New Guinea should make their own choice. This gives the events of June 1971 their special significance: they were primarily the expression of growing independence; and it is important to remember that the issue was land and not the future constitution.

It was perhaps unfortunate that the withdrawal of the bills left the doors to the past ajar. A crushing defeat (which was quite possible) would have cleared the air for a fresh start. On the other hand, it was probably too early for that. As it was, the Administration had the opportunity of pursuing its chosen course: to maintain that everyone would gladly accept the bills once they had been properly explained. The offer still stood, but it was final. Although the Administration could rightly claim that it had never pushed for its acceptance, it was also not prepared to consider any alternatives. For this reason it strongly opposed a motion calling for a commission of inquiry which was introduced in the House in September 1971. The Administration was playing for time and it won: the motion was defeated.

These tactics left a bitter after-taste. They first of all confirmed that the Administration had never intended to subject its land policies to 
a critical review, but had merely looked for ways to implement them more effectively. Further, they increased the suspicion that the bills were not even an attempt to grapple with the land problems as the Administration saw them, but rather an exercise in shadow boxing. Did the Administration use the bills just as an alibi for not coming to grips with touchy land issues during the final stage of decolonisation? There are obvious advantages for a colonial power in spending the last few years of its administration drafting legislation for the historical record instead of getting involved in controversial policy discussions or being forced into making unpopular practical decisions. There is nothing sinister about such an attitude, but it is not exactly helpful.

When the National Coalition Government took office after the elections in February 1972, it was clear that the land bills would not be teintroduced, as all its member parties had supported the motion calling for a commission of inquiry. Instead an amended version of this motion was introduced in June and passed without opposition. The speech by the mover, Obed Boas, Member for New Ireland, shows how the feeling of independence had grown since the previous year:

I strongly believe that land reform in our country must be based on our customs and cultures primarily, with suitable clauses from land legislation from other countries instead of 'drafted land reforms' copied from other countries - land legislation pressed upon us to accept and to use in Papua New Guinea which would and will only cause bloodshed and death among our people (House of Assembly Debates, 1972 vol. 3: 387).

Was this the bang as the door was closing on the colonial past? The sound was certainly frightening for many. It seemed to call for a return to an imaginary tribal past rather than for a sober assessment of present problems and future needs. The attitude expressed by Sinaka Goava, Chairman of the Commission of Inquiry into Land Matters, appointed as a result of this motion, does not suggest that the pendulum will swing to this extreme:

let me say at once that it is not a simple matter of traditional custom versus introduced Western Law. A discussion of land matters in these terms is utterly unhelpful. The Commission has from 
time to time, heard mostly-I regret to say-from students and some politicians blunt statements that before the Europeans came, Papua New Guineans knew their land boundaries and could adjust all disputes peacefully and harmoniously. Such people are inclined to say that all we have to do is to get rid of Western courts, Western titles, Western cement pegs-and all would be well. This is perhaps understandable language in these days of de-colonisation, but the sooner we get through it and get down to more hard-headed examination of land problems and solutions for them, the better (1973:1).

The Commission began its work early in 1973. It aimed to submit an interim report in June and its final report in September or early October. These reports, however, can only be a first step. Before any legislation can be drafted, important policy decisions have to be made. The Commission is fully aware of this.

Now it is not the task of the Commission of Inquiry into Land Matters to recommend on these policy questions. We are, however, asked to report on a range of workable alternatives and to evaluate them. We will do that, and we hope that the Government and Legislature will have thought through their basic social, economic and political philosophies so that policy decisions on how specific land problems are to be handled can be made quickly and according to some clear sense of social purpose (Goava 1973: 4).

The issue of the Post Courier (7 May 1973) which reported this optimistic statement also included the gloomy prediction by Albert Maori Kiki, the Minister for Lands and Environment, that it could take a century before the tensions created by the land problems in Papua New Guinea would ease. Now it is clear that the people of Papua New Guinea will need all the optimistic energy they can mobilise and that a defeatist attitude will spoil all their chances. But to underestimate the dimension of the problems with which they are faced is equally perilous. Sinaka Goava is undoubtedly right when he says that a discussion of land matters in terms of traditional custom versus introduced Western law is inadequate. Still, a hard-headed examination of land problems and possible solutions may be the least difficult part of actually solving them. If they could be treated in 
isolation this would be a sensible approach, but they are part of general political and ideological problems which have to be handled in quite a different way. To solve them, it may even be necessary to pretend that land matters are simply a matter of traditional custom versus introduced Western law.

The problems of choice facing the country are so vast and intricate that it is unrealistic to expect that Government and Legislature will have thought through their basic social, economic, and political philosophies in any meaningful way in a matter of months. And if they had, it is highly unlikely that all or even a large majority of the members of the Government and the Legislature would agree. None of the choices Papua New Guinea can make is objectively right or wrong, none is prescribed by existing facts. It is not simply a question of obtaining the expertise and the capital for doing what needs to be done, nor is it a question of convincing the people that what they want to do cannot be done. The people of Papua New Guinea have still to make up their minds about where they want to go.

The range of possible choices confronting Papua New Guinea at present is perhaps greater than that faced by any country ever before. Yet, despite this range, it is impossible to adopt a social, political, and economic program which will please everybody: there are already considerable conflicts of interests, aspirations, and convictions. Under these circumstances people naturally tend to hide problems in the hope that time will make them disappear, instead of bringing them out into the open in an attempt to solve them. This technique may succeed only too well. The problem of choice will disappear but so will the promises, and the problems which made choice difficult in the first place are likely to have increased in the meantime. The line of Ieast resistance usually leads into a bog. Whether it likes it or not, Papua New Guinea has to go through a long and diffcult process of decision-making, and its people will have to pay dearly if they do not face up to their responsibility.

In a way Papua New Guinea is a lucky country: it has plenty of suitable land to feed its people, enough mineral wealth to provide them with a great deal more than the 'essential' services, it has no serious environmental problems, no threatening neighbours. Its colonial past has only shaken but not cut the links of the people with their own 
traditional cultures, and these cultures are close enough to be forged into a common basis. The objective preconditions for finding a satisfying balance between the needs for continuity and change, the needs for unity and diversity, and the needs of the individual and the community are certainly there.

But this is no reason to be content. The problems are there too. They lie within the people, and there are at present no outside pressures strong enough to force them into striving for this balance. The people are not united in their fight against hunger, or by a revolt against colonial suppression or the fear of foreign aggression. There is nothing to compel them to create the new type of society they need to survive. If the people of Papua New Guinea want to avoid fighting each other they have to unite in their fight for their common future. They need a positive, a cultural revolution. It matters little what ideals and goals are chosen, as long as they provide a common bond between people who are prepared to work and to make sacrifices for them.

If this revolution succeeds, Papua New Guinea has every reason to look with confidence to the future. If it does not get under way soon, anything can happen. It need not be anything dramatic. There are much safer, quiet roads to disaster. In a few decades Papua New Guinea may look like this: its mountains denuded of forest and scarred by erosion. The topsoil out in the sea or at the bottom of the dams for a few huge hydro-electric schemes, supplying power to a few equally huge mines, each surrounded by some prostituted model villages. Along the coast, run-down plantations and stagnating towns strangled by mushrooming squatter settlements. A handful of glamorous tourist resorts where the new élite wastes its money on champagne and white girl friends. Certainly occasional attacks on the cargo convoys along the highways (both sides armed with sub-machine guns) and probably the silent terror of secret societies. Corrupt politicians (mostly abroad). The black supreme court judges in their tapa robes the only ones still calling each other 'brother'. As for the rest: forgotten hamlets among diseased cocoa, coffee, or tea which is not worth picking; broken pumps and disintegrating aid posts; hamlets which the white-socked public servants are reluctant to visit and have long crossed off their lists. But there is plenty of internal revenue as well as foreign aid, and an impressive homegrown constitution. In short: a sick country, its 
lands spoiled, its people plagued by greed and envy, still nursing their, by now, entirely fictional, colonial grievances and still dreaming of a glorified traditional past which they were not strong enough to turn into the basis for a decent future.

One could paint a large number of equally depressing or glowing pictures. The future of this country is wide open. How it will look depends to an unusually large extent on what the people make of it. It may be important to remind them that they can not only ruin their own lives but also their land, and that for ever. The deep feeling of the people for their land-as living space, as a source of life and social cohesion, not as property-may be the only force strong enough to unite them for a successful battle for their own and their country's future. What will become of Papua New Guinea will not depend on its constitution, foreign aid, mineral finds, the role of the army, the honesty of its politicians and public servants, or the success (or otherwise) of secessionist movements-in the end it will depend on whether or not the people have the strength to live with (and not off) their land and to share it among themselves as they have done in the past. If they can do this, both the land and the people will survive; otherwise the only question is: who will be ruined first? 


\section{The historical dimension}

\section{P. Chatterton}

In the middle and late 1940s, the people of Papua New Guinea were recovering from the more or less traumatic experiences of the war years. All of them had been subject to military rule, either Japanese or Australian. This rule, which assumed varying degrees of brutality and benevolence at different times and in different places, had one invariable feature. For Papuans and New Guineans it meant doing as they were told-or else. It also meant accepting what they were told and no nonsense. There was no time for argument or even for explanation. In the area of land usage, it meant watching soldiers, sometimes white, sometimes yellow, doing what they liked where they liked when they liked with the ancestral lands.

The rule of law was re-established progressively during the late 1940s. The same period saw a tremendous increase in the expatriate population, with consequent increased demand for land for development. This was particularly so in the Port Moresby area. Due to its having become the capital of the whole country, instead of merely that of Papua, Port Moresby's population had snowballed from a few hundred before the outbreak of the Pacific war to several thousand almost as soon as it was over. It is true, of course, that during the war years military personnel in the area had run into many thousands, but as the populations of the indigenous villages had been evacuated, it was not until after the war that the impact of this spectacular increase was felt by the native people.

With steadily increasing governmental activity, Papuans and $\mathrm{New}$ Guineans soon came to realise that their land had a value in the eyes of the white men far in excess of anything they had envisaged in the past. This realisation had two effects: first, it made them cagey about selling their land, and second, it caused them to look with increasingly critical eyes on the land sales of the past, when their grandfathers had disposed of very large areas of land for what now looked like ridiculously small payments, payments moreover made not in cash but in knives, axes, cloth, tobacco, and such-like commodities. 
As to the first effect, the law relating to land sales tended to increase sales resistance. Land-owning groups could not sell or even lease their land to any but the Government, and while the Government could lease land from indigenous owners, it showed a marked reluctance to do so and a strong preference for outright purchase-at its price. It is hardly surprising that thinking Papuans and New Guineans who had observed that the white man's world is a competitive world, looked on this situation with dark suspicion.

The criticism of early land sales took three forms. It was alleged that the prices paid were too small. It was claimed that those who sold the land didn't understand that it was ownership rather than usage which was being alienated. Finally it was said that in many cases the payments had been made to the wrong people anyway. These claims have been the subject of a good deal of argument and counter-argument, most of it fairly fruitless. As to prices paid in early land purchases, no one, as far as I know, has really done his homework on this issue. To find out whether the payments were or were not adequate, it would be necessary to calculate the value of the goods handed over at thencurrent prices, and then to compare those cash values with the sort of prices that were being paid for comparable land at that date in situations in which both vendor and purchaser were of the same skin colour and at the same level of sophistication. The complaint about payments in kind rather than in cash has not in itself much substance; the original vendors probably preferred it that way. A reliable answer to the question of whether the early vendors of land understood what they were doing is no longer recoverable, since those involved are all dead and, being illiterate, have not left behind them any record of what they thought they were doing.

However, having examined some of the early purchase documents which have survived (many have disappeared), my own feeling is that there was a very fruitful field for misunderstanding, due largely to linguistic problems. Looking at the documents with a background of long experience in translating from English into Motu, I have a lot of sympathy with the interpreters who had to try to make the meaning of their contents clear in the vernacular, and a tolerable certainty that they could not have made a very good fist at it. If a government officer asked: 'Whose land is this?', the answer, in that part of Papua with 
which I am familiar anyway, would be 'The such-and-such descent group's land'. But if the question was put in the form: 'Who is the owner of this land?', the interpreter could hardly avoid using a word which, at least in the context of land, does not mean 'owner' at all, but refers to the headman of the land-owning descent group, who by custom controlled the use of the land. Whether such a man had authority to dispose of ownership as distinct from usage on behalf of the group is largely an academic question, dealing as it does with a situation unlikely to arise under pre-contact conditions.

It would, I think, be fair to say that the concept of 'ownership' of land did not exist. Certainly the concept of 'indefeasible title' did not. How could it in a highly fragmented society in which might was right? The basic concepts in relation to land were those of occupation and usage. Land was occupied and utilised by a group for as long as it wanted to occupy and use it and was strong enough to eject intruders. It might, of course, and often did, grant to outsiders the right to utilise certain areas. Once the colonial government started to buy land, these outsiders might well have found it profitable to regard themselves as the 'owners' of such land, thus giving in some cases substance to the claim that the wrong people had been paid for it.

But who, in any case, were the right people? The arrival of the white man and the establishment of colonial government had the effect of freezing a situation which had previousiy been fluid. Papua New Guinea's oral history is full of stories of migrations. Groups migrated as a result of pressure from powerful enemies or voluntarily in search of fresh fields and pastures new; and the lands they had left were occupied and utilised by others. Does it make sense to regard a group which happened to be occupying a particular area at an arbitrary point in time as being its 'owners' with 'indefeasible title'?

In such a situation, and in the face of a growing awareness among Papuans and New Guineans of the concept of land as a commodity and a very valuable one at that, it is not surprising that neither of the statutory bodies set up in the post-war period to resolve' it has had much success. The Native Lands Commission, set up in 1952, was replaced by the Land Titles Commission in 1963, with wider powers than its predecessor. The Commissioners have pursued their inquiries 
with tremendous patience and perseverance, and have amassed an enormous volume of valuable information about land tenure customs throughout the length and breadth of the country. But there have been very long delays in both the hearing and the determination of the claims brought before them; and in many cases unsuccessful litigants have just not been prepared to accept an adverse decision, and have resorted either to appeals against the decisions or to violence.

At the same time at which the Land Titles Commission was set up in 1963, there were also enacted two measures relating to land tenurethe Land Tenure Conversion Ordinance and the Land Registration (Communally Owned Land) Ordinance. The Land Tenure Conversion Ordinance provided for the conversion of communal tenure to a limited number of individual tenures to be held by that number of rightholders, provided that the remaining rightholders unanimously agreed to surrender their rights. It had been the intention of the Administration that a substantial majority of the rightholders should be able to authorise such conversion, but the indigenous members of the then legislature-the Legislative Council-insisted that there must be unanimous agreement before a conversion could take place. Perhaps because of this requirement, little use has been made of this Ordinance; and in the area in which it has been extensively utilised, the Northern District of Papua, the rightholders who were surrendering their rights either did not understand, or did not want to understand, what they had done and continued to make traditional demands on their kinsmen who had been granted, on paper, individual tenure.

The second measure, the Land Registration (Communally Owned Lands) Ordinance, which provided, as its title implies, for the registration of communal tenure by rightholding groups, was never used at all, and its operation was suspended by the House of Assembly in 1971.

From 1969 onward the Administration addressed itself to the task of re-casting the land laws. A study group led by the Director for Lands, Surveys and Mines, Don Grove, visited Kenya, and two experts on Kenyan land tenure matters, Messrs Rowton Simpson and Fleming, visited Papua New Guinea to study the local situation and tender advice (see Rowton Simpson 1971). With almost incredible maladroitness, considering the date, this was exclusively an expatriate exercise. As a consequence, a group of four very comprehensive bills was brought 
down in the second House of Assembly in 1971. A tremendous amount of hard work had gone into the preparation of these bills, but they were unceremoniously rejected by the House, which after seven years of Administration domination was beginning to flex its muscles.

There were probably three main reasons for the rejection. There was resentment that the Grove Study Group had been an all-white one. There was also suspicion that the Group's concentration on the Kenyan model and its failure to visit neighbouring Tanzania indicated a bias towards individual and away from communal solutions. And finally, many members were influenced in their thinking by a highly critical paper written and circulated by Dr Alan Ward of Monash University (1972), whose own experience with Maori land tenure problems in New Zealand had caused him to form an unfavourable opinion of the bills. Be that as it may, the bills were rejected, and as the life of the House was drawing to a close the whole matter was shelved.

The third House of Assembly, which met for the first time in mid1972, was the first in which elected rather than official members assumed leadership of the Legislature. Michael Somare became Chief Minister at the head of a Coalition Government in which the Pangu Party was the senior partner. An early decision of the Somare Government was to appoint a Commission of Inquiry into Land Matters.

At this juncture, therefore, any attempt to look into the future involves a substantial measure of crystal ball gazing. However, I will attempt it. I think that it may be safely said that developments in connection with land tenure and land usage will be determined by three general trends: decentralisation of the control and registration of land; the restoration of alienated land to indigenous ownership; and a movement away from communal towards individual tenure. It may be noted that the first and third of these trends are simply parts of more general trends in these directions.

Decentralisation was one of the recommendations of Rowton Simpson in 1969, and it will be very surprising if it is not one of the recommendations of the Committee of Inquiry into Land Matters. It will probably take the form of the setting up of District Land Boards and the establishment of District Land Registries. The creation of separate and distinct District Land Boards will be simply an extension 
of the present Lands Department policy of supplementing its central Land Board personnel by additional local members when sittings are held in various districts. But the establishment of District Land Registries in place of a Central Registry will be an entirely new development, designed to ensure the maintenance of accurate and upto-date registration, and also to make information contained in the Registry more readily available to the public. One thing is sure: the registration of traditionally owned land, mammoth task as it is, must be undertaken as soon as possible. The longer it is delayed the more difficult it will become, and the larger will be the volume of bogus tradition which will be asserted.

Will the adjudication of disputes over land 'ownership' also be decentralised? In view of the widespread dissatisfaction with the Land Titles Commission evidenced in submissions made to the Commission of Inquiry in the course of the public hearings which it has held in a number of centres, this seems very likely. But just what form the adjudicating bodies will take cannot be predicted. It can, however, be safely said that they will have to be very wisely structured if their findings are to secure better acceptance than has been accorded to those of the Land Titles Commission.

There will also need to be very clear definition of what are to be the criteria upon which decisions are to be reached. Is the criterion to be actual and effective occupation at the time of the establishment of colonial rule in the area concerned? Or is it to be actual and effective occupation at the time of Independence? Or is it to be one of equity, that is to say, which of the contenders for title has most need of the land and will be most likely to utilise it effectively? The first of these criteria is pretty artificial. The second sounds somewhat bizarre, but a committee inquiring into the current breakdown of law and order in the Highlands has suggested that it is widely believed by Highlanders, and that some of the fighting going on just now over land arises from the belief that the more land they can grab before Independence, the more they will be able to claim legal title to in an independent Papua New Guinea. The third suggested criterion makes the best sense, but it is to be doubted whether it will gain acceptance.

The question of the utilisation and development of land will loom large. Currently a lot of facile lip service is being paid to the proposi- 
tion that land must not be allowed to lie idle but must be brought into productive usage. But will a democratically elected government be prepared to court unpopularity by getting tough with those who allow their land to lie idle? Public declarations of enthusiasm for the gospel of development may be misleading. Papuan and New Guinean communities are generally enthusiastic about the Government getting tough with the people in the next village or the next valley, so long as it doesn't get tough with them. So movement towards a tough policy on land utilisation will probably be slow and cautious.

Transfer of alienated land back to indigenous ownership will probably go forward fairly rapidly. The first transfers will be of land which has been declared 'waste and vacant' (in Papua) or 'ownerless' (in New Guinea), and has consequently become Administration land without payment to anyone. This has always been a sore issue. A nowprominent Papuan politician once declared that early government officers had steamed along the southern Papuan coast five miles off shore and declared 'waste and vacant' any area from which they could not see smoke rising. While this may be a picturesque exaggeration it is safe to say that some of these declarations were made on pretty inadequate evidence. The findings of the Native Lands Commission of 1952-63 largely confirmed indigenous claims that there was no such thing as 'ownerless' land in Papua New Guinea. So transfers back to indigenous ownership of waste and vacant land will be a popular exercise, though we may expect a good deal of strife over the issue of to whom it is to be returned. In some cases, of course, it will involve the compensation of lessees. Closely related to these lands are those in New Guinea which were confiscated by the pre-1914 German Administration as punishment for various offences perpetrated, or alleged to have been perpetrated, by the rightholders.

Next for return will be Administration land which has since its purchase remained unutilised, either by the Administration itself or by lessees to whom it has been leased. Finally, there will be the purchase, or resumption with compensation, of developed land for distribution to indigenes in cases where land is in short supply. This is a process which has already begun. A hard look will probably be taken at the early freehold grants (there have been none since Australia took 
charge). Any proposal to convert them to leaseholds will no doubt be strongly resisted, but will probably prevail.

Shall we hear more of an even more radical proposal put forward recently by $\operatorname{Dr}$ John Hookey of the Australian National University during a discussion at the Seventh Waigani Seminat in Port Moresby? Dr Hookey suggested that as leases granted by the colonial Administration (in most cases for ninety-nine years) expired, the land should revert, not to the Government, but to the descendants of the original rightholders. Dr Hookey added, perhaps facetiously, that they could be required to hand back the axes, knives, and laplaps with which their forebears were paid. Under such a plan, the Government would lose a lot of money from rentals, but would be saved from having to continue to play the potentially unpopular role of universal landlord. Even if the wholesale adoption of so revolutionary a plan were considered undesirable, there could be merit in so returning land purchased in the pre-Australian period, that is, before 1906 in Papua and 1920 in New Guinea. These are the purchases about which resentment has been most rife, and in some cases not without reason.

Finally, and in spite of the failure of the Land Tenure Conversion scheme of 1963, we may expect to see a movement away from communal and towards individual tenure. This process will be rationalised by what may be called 'instant tradition'. Already traditions are being thought up overnight to bolster an argument or to turn a quick dollar, and are served up next day as 'the custom of our people from time immemorial'. In the part of Papua I know best, where land tenure has always been by descent groups, there is a growing tendency for nuclear families and even individuals to claim absolute ownership and right of disposal over those parts of their descent group's land of which they had traditionally had rights of usage. And the young men stoutly maintain that this was the custom 'from time immemorial'. Within the last few weeks, a Highland leader has suggested that individual tenure may be the answer to the problems of his area. I don't think that he tried to claim that it was 'traditional'. Perhaps the Highlanders are less worried about tradition than the people of the coast. Whether this movement from communalism to individualism can properly be described as 'progress' is a matter of opinion. I am one of those who have reservations about it. But for good or ill, it is 'on'. 


\section{The limits of choice}

\section{E. J. Clay and M. C. Evans}

Our objective in this paper is to identify and measure the additional pressures that will be imposed on the land resources of Papua New Guinea by such factors as population growth, the migration of population from rural to urban areas, changes in export and import substitution policies, and economic development in general. We consider that decisions on land problems must be taken in full awareness of the wider context in which they occur, in particular with regard to the strength of future demands for land to be used in one activity or another. Short-sighted judgments now will make it more difficult to find the solutions later when the pressures will have become even greater.

Why the future demand for land is important in a country which has a low population density and latge tracts of virtually unexploited land should perhaps be clarified. Land is required as a factor of production in agriculture, to provide space for industry in the modern sector, or as little more than a raw material in extraction industries (such as mining or the cropping of primary forests) and for human living space and communications. In Papua New Guinea, land also fulfils important social functions which are interwoven with these economic uses. As Papua New Guinea's economy and its population grow, these functions all mean additional demands for land which in some situations may conflict with each other.

These changes in demand have to be set against the rate at which land can be made available at each point in time, not against the total stock of undeveloped land, which is considerable at present in relation to the size of the population and level of economic development. For it is this balance of potential demand and the supply which is forthcoming which determines the relative scarcity of land. Simply how much land can be allocated to different uses, and at what cost, has the most far-reaching economic and social consequences. Relative scarcity may frustrate necessary or desirable developments and create serious political problems. This is often caused by attempts to match supply to overly ambitious levels of projected demand. When land scarcity 
is thought of in these terms, some indication of the extent to which it may become a problem in the future can be obtained by projecting land requirements for different uses.

In looking at the causes of the growing demand for land, it is important to distinguish between those factors which are largely beyond the control of policy-makers in Papua New Guinea, and those which are more responsive to government action, or indeed are direct consequences of choices between alternative strategies. Most important amongst factors which will be unaffected by policy decisions, at least within the foreseeable future, is population growth. Even if birth control programs were implemented in the next few years, they would have negligible impact on population expansion before the 1990 s. Then there is Papua New Guinea's external economic environment, particularly movements in primary commodity markets which determine the prices given for exports and so affect incomes and employment opportunities within the country. Equally important are the prices of goods consumed domestically, which again are largely dependent at present on developments in external markets through import prices. When the latter rise faster than export prices, producers of the commodities involved must increase the quantity of exports in order to maintain their level of real income.

There remains, nevertheless, considerable choice concerning changes in the economy, which are to some degree subject to government regulation. These relate to questions such as how fast the economy is to grow, what the relative growth rates in urban and tural incomes should be, who should own the means of production and distribution, and in more detail, whether, for instance, the expansion of agricultural exports should be encouraged at the expense of increasing food production for the home market. Decisions on these issues all imply variations in the growth of demand for land for different uses. The interaction of policy decisions with forces in the external environment of the economy are complicated, and to relate the outcomes to policy objectives is not an easy task. As an example, consider the problem of estimating the overall impact on real incomes in rural areas of a policy aimed at the expansion of agricultural exports, where there are changes in the external prices for the relevant commodities and the inputs used in their production, there is population growth and there are different 
average levels of efficiency for smallholdings and estates.

The economist's way of coping with the complexity of such situations is to construct a model which represents in summarised form the main relationships linking the most important factors, or variables, in the process. Very often it is only possible to look at part of the picture in any detail, the remainder being represented by a few broad assumptions. This is what we have done elsewhere in applying a model to questions concerning the future development of Papua New Guinea's agriculture. Such details as the quantities and prices for individual crops which can be expected in the future are taken into account, but projected changes in the manufacturing, mining, and service industries are summarised in a single figure representing the growth rate in urban sector incomes. This same set of relationships, describing the economic structure of Papua New Guinea's agricultural sector and its main links with the rest of the economy, is used here to project the demand for land which will be generated by different patterns of economic transformation in rural areas. These patterns will be defined in terms of the 'autonomous' changes in the economic environment, the growth of indigenous incomes, the relative share of smallholdings and estates in future agricultural expansion, and the proportion of total output contributed by the different export and import-substituting crop and livestock products.

At the time of the 1971 Census, Papua New Guinea's indigenous population (2.5 millions) was probably growing at a rate in excess of 3 per cent a year after accelerating through the previous decade. The factors which contributed to the past increase in the rate of population growth-public health measures, the breakdown of traditional restraints on fertility, etc.-will continue to operate. In the absence of reliable forecasts, we have assumed that the total population will grow at 3.25 per cent a year. This growth will be unevenly spread across the country, mainly because migration will continue to swell the urban population. In the five years up to 1971 the urban population (representing about 9 per cent of the total population in 1971) grew at an average rate of more than 12 per cent a year. With an expected reduction in the rate of growth of urban sector economic activity, and an increased emphasis in rural areas, we have assumed an annual rate of growth in the urban population of only 8.5 per cent with two- 
thirds of this increase being migration into urban areas. This is perhaps still higher than advocates of a rural based development strategy might wish for, but in view of past behaviour and the experience of so many less developed countries, to assume a lower rate appears unjustified. These figures mean a growth rate of 2.5 per cent a year in rural population.

Any increase in Papua New Guinea's rural population must mean an increase in the local production of food if current nutritional standards are to be maintained, unless the extra demand is met by imports. If there is no increase in the productivity of land the area annually cultivated must increase by the same percentage. The projected growth rate of 2.5 per cent will increase population and the minimum demand for land for food production by nearly 30 per cent by 1980 .

Much of the land is cultivated in rotation with long fallows, so it does not automatically mean that this much additional land will have to be taken up for gardens, because part of the pressure will be satisfied by reducing the period of fallow. In many areas where the population is sparse this will not affect the productivity of land which is currently rested for a longer period than is necessary for a restoration of fertility. However, where there is already great pressure of population, as in the Chimbu Valley and the Gazelle Peninsula, this may no longer be possible, and further reductions in the periods of fallow would result in diminishing productivity, that is a reduction in yields per acre if gardening techniques remain unchanged. In these circumstances, only more land can satisfy the increased demand for food without a reduction in nutritional standards, unless action is taken to raise productivity through the use of new agricultural inputs and yield-increasing improvement in crops.

The growing population will also make additional demands for living and working space. In rural areas Melanesian patterns of land use are unlikely to make this a problem. In urban areas, the problem already exists. The projected growth rate of 8.5 per cent a year will lead to an increase in the urban population of over 130 per cent by 1980. Unless there are increases in urban housing and commercial densities, analogous to increased agricultural productivity and reductions in fallow, then the supply of fresh urban land must keep pace with this growth in population. The problems already being ex- 
perienced in acquiring land for urban use in several major centres make this a daunting prospect.

The other major determinant of the growing demand for land is the expansion of commercial agriculture. At the beginning of the current decade, agricultural production contributed 12.6 per cent of the total value of marketed output in the Papua New Guinea economy. If development strategies currently being planned are successful, ${ }^{1}$ this proportion is expected to fall to 9.8 per cent by the end of the decade, as other industries, particularly copper mining, increase their contribution to national income. However, even though agriculture's share of national production will become smaller, it is being called upon to increase production by $\$ 37$ million over the period $1970-8$, representing an annual growth rate in physical output of 4.9 per cent. These figures relate only to marketed agricultural production. It is also planned that non-marketed agricultural production (mainly subsistence output) should add another $\$ 35$ million worth to the economy by the end of the seventies. When it is also considered that forest production is expected to expand rapidly, it is clear that the land-using industries are expected to make a major contribution to increasing Papua New Guinea's income.

The implications of these plans in terms of land requirements, whether for improvement or development, as in agriculture, or in terms of a larger exploited area, as in forestry, will depend on two key factors. The first is the particular types of rural activity that are to be encouraged. The cash returns per acre vary for the different crops and animals produced, as well as for the different methods of management being used. Fewer acres are needed to provide a given net income on an intensively-managed cocoa and copra estate than on an extensively-farmed cattle smallholding. The second is the extent to which different forms of agriculture can provide opportunities for indigenous enterprise, for a rapid increase in the proportion of the economy under Papua New Guinean control is one of the objectives of the Government's development program.

1 Most of the information on current development plans used in this paper is based on Papua New Guinea 1971a, Papua New Guinea 1973a and Parker 1973. 
These factors are clearly interrelated: those types of farming which result in high returns per acre require proportionately higher inputs of capital and management expertise than agricultural systems which are less land-saving. Since the former will tend to be owned by expatriates, a policy aimed at increasing indigenous control of the rural economy suggests an emphasis on expanding production from holdings on which land productivity is relatively low and on which the scope for raising it in the near future may not be very great or even very desirable.

No official statements regarding desired changes in agricultural acreages beyond 1975 have been released, but by making certain assumptions it is possible to translate the available figures for planned production increases into areas of land which will be required. It is important to appreciate that the figures in a plan are (usually optimistic) targets which the planners would like to see achieved. They represent objectives which are considered feasible: if all goes well they could be attained. What will be achieved may turn out to be entirely different. The distinction between the estimated amount of land needed, based on plans, and the realities of the amount of land available has been highlighted in recent years by the difficulties encountered in obtaining land scheduled for agricultural development, particularly for oil palm and cattle ventures. For example, it has been estimated that, of 206,000 acres proposed for purchase for development and later release during the first two years of the first five-year development program, only 34,000 acres were actually acquired (Parker 1971: 87). Such problems of land supply were a major component in the downward revision of many agricultural targets of this initial development program.

It is clear that there is a range of possibilities regarding land use in Papua New Guinea between now and 1980, reflecting not only changes in circumstances beyond government control, or the deliberate policy choices which can be made, but also changes due simply to difficulties in implementing the chosen policy. Our approach is to consider the outcomes, in terms of changes in land requirements between 1970 and 1980, ${ }^{2}$ of lower and higher levels of economic

2 For certain types of land use 1970 had to be used as the base year from which projections were made since insufficient data were available for 1971. 
performance for Papua New Guinea. In some respects, these can be looked upon as' 'optimistic' and 'pessimistic' projections, reflecting both the favourable and the unfavourable circumstances that may relate to foreign aid and investment, manpower supplies, mining developments and so on (which affect agriculture indirectly via the demand for marketed food) and overseas trading arrangements (which may directly affect prospects for Papua New Guinea's export crops). We have concentrated our attention on the implications of two possibilities for rural development: that targets planned for the end of the 1970s are reached, or that actual production in many sectors of the agricultural economy falls well short of target.

The influence of the 'autonomous' factors in the economic environment is assumed to be the same for both the lower and higher performance levels. Thus the rural population grows by 2.5 and the urban population by 8.5 per cent annually in both cases. The other important assumption which is not varied is that of a steady deterioration in the terms of trade for export agriculture. There is no indication of any long-term improvement in the agricultural commodity position on world markets over that of 1970, whereas import prices in Papua New Guinea can be expected to increase as in the past, that is by at least 1.5 per cent a year. We also take this to mean that the price of goods sold on the country's internal markets, and which determine the cost of living to those in the monetary sector, will rise at the same rate.

What distinguishes our Iower and higher performance projections for the rural economy is essentially as follows. First, the quantities of crop and livestock products supplied to the domestic markets grow at or near the intended rates (we take 7 and 12 per cent a year respectively) in the higher projections, but grow at only about half these rates ( 3.2 and 6 per cent) in the lower projections. Similarly, the development of the oil palm industry attains only half the target currently scheduled under the lower performance assumptions.

Second, in the slower growing economy, it is assumed that there will be no further expansion in export production from non-indigenous estates, apart from that resulting from some additions to the expatriateowned oil palm area. In the faster growing economy, however, nonindigenous estate production increases by 3 per cent per year. This is actually a little less than planned at present, but such a growth rate 
represents a feasible rate of increase in land productivity, so that the extra output need not use up much more land-a situation which may be more in harmony with future policies.

Third, of the existing shortfall between total consumption and homegrown supplies of fruit and vegetables, only one-fifth is assumed to be made up by domestic producers by 1980 under the lower projections, while half of the 1970 gap is closed through import substitution by the end of the present decade under the higher projections. This assumption, which is partly based on different possible values for the income elasticity of demand for these foods, accounts for the two growth rates cited above for internal marketings of food crops.

Finally, in the slower growing economy, production is only sufficient to maintain the real value of average cash earnings per capita of the indigenous population engaged in commercial agriculture at their 1970 level. With the higher projections, on the other hand, real per capita indigenous incomes in rural areas would increase each year by an average of at least 1 per cent, which is in line with current plans. For these reasons, the lower and higher performance development paths will be referred to as the 'zero growth' and 'medium growth' projections from here on.

What we have done therefore is to assume certain rates of change (based on available information about future development programs) in the marketed output of home-grown crop and livestock products, non-indigenous export crop production, and per capita real incomes of the indigenous rural population. The missing piece in this economic jig-saw is export crop production on smallholdings, which has seen a rapid expansion during the previous decade. If current objectives are achieved, it is estimated that smallholder export production will grow at just under 5 per cent per year between 1970 and $1978 .^{3}$ The smallholder export sector is an unpredictable element in the rural economy because its prospects are more susceptible to change, due to sudden movements on world commodity markets, than either the livestock or market gardening sectors, for which a strong excess demand on internal markets is assured. We have therefore not assumed a priori any particular rate of growth in smallholdings. Instead, we calculate the 
minimum expansion in smallholder export production needed to maintain the 'zero growth' and 'medium growth' indigenous real income situations, given the assumed growth rates for estate, livestock, and home-consumed crop output and the population and price changes mentioned earlier. ${ }^{4}$

The contribution to national rural income which would be required from smallholdings in the 'zero growth' and 'medium growth' economies can be expressed as follows. In the former, where expansion of other types of agriculture falls well short of the targets presently planned for them, a 4.7 per cent annual growth in smallholder export crop production would be needed simply to prevent average real per capita incomes from falling as the indigenous population and the cost of living both rise. If there were no significant increases in average yields per acre on smallholdings during the next seven years, the total area of smallholder land required for export crops would have to be 60 per cent greater in 1980 than the area used for this purpose in 1970. It is interesting to note, from the point of view of regional income distribution, that oil palm smallholdings would account for a little more than one-tenth of this extra acreage.

In the 'medium growth' economy, only a 47 per cent increase in the smallholder area under export crops would contribute sufficient income to enable the 1 per cent annual growth in per capita real incomes to be realised. This represents a rate of increase of 3.9 per cent a year in smallholder export crop production, provided again that average yields per acre do not change. Of the extra land required, just under one-third would be needed for oil palm development, given existing plans. If, in fact, the 60 per cent increase in smallholder export crop production also occurred, along with the 'medium growth' achievements of the other sectors of the rural economy, then indigenous real per capita incomes in agriculture would increase by 1.5 per cent a year. Such a growth rate in income would provide a considerable stimulus to village industry through the increased purchasing power of the rural market, and might help reduce the flow of people into urban

4 Several supplementary projections must aiso be made; for example, future changes in the capital/labour proportions in different agricultural activities must be taken into account. 
Table 1 Projected increases in land area under export tree-crops and beef cattle pasture, 1971-80

\begin{tabular}{llll}
\hline Type of & Approximate area & Projected area & $\begin{array}{l}\text { Percentage } \\
\text { change in area* } \\
\text { Holding }\end{array}$ \\
& in 1971 & in 1980 & $1971-80$ \\
\hline
\end{tabular}

\section{'Zero growth' assumptions}

\begin{tabular}{|c|c|c|c|}
\hline Export crops & & & \\
\hline Indigenous & 448 & 727 & 62 \\
\hline Non-indigenous & 465 & 477 & 3 \\
\hline Total & 913 & 1204 & 32 \\
\hline $\begin{array}{l}\text { Grazing } \\
\text { All holdings }\end{array}$ & $302 \dagger$ & 675 & 123 \\
\hline TOTAL & 1215 & 1879 & 55 \\
\hline
\end{tabular}

\section{'Medium growth' assumptions}

\begin{tabular}{|c|c|c|c|}
\hline Export crops & & & \\
\hline Indigenous & 448 & 667 & 49 \\
\hline Non-indigenous & 465 & 491 to 653 & 6 to 40 \\
\hline Total & 913 & 1158 to 1320 & 27 to 46 \\
\hline $\begin{array}{l}\text { Grazing } \\
\text { All holdings }\end{array}$ & 302 & 1350 & 347 \\
\hline TOTAL & 1215 & 2508 to 2670 & 106 to 120 \\
\hline
\end{tabular}

\section{'High growth' assumptions}

Export crops

Indigenous

Non-indigenous

Total

Grazing

All holdings

TOTAL

\section{8}

465

913
735

491 to 653

1226 to 1388
64

6 to 40

34 to 52

\section{7}

$\frac{302}{1215} \frac{1350}{2576 \text { to } 2738}-\frac{347}{112 \text { to } 125}$

* Based on assumed grazing requirements of 3 acres per beast on improved pasture and 8 acres per beast on unimproved pasture

$\uparrow$ Recorded pastoral area of non-indigenous holdings plus estimated requirements of smallholder cattle herd 
areas in search of employment. We shall refer to this projected state of affairs as a 'high growth' economy.

The overall requirements implied by these three rates of income growth for land on which to grow export crops and raise beef cattle in 1980 are shown in Table 1. A range of acreages for non-indigenous export production is given corresponding to the 0 to 3 per cent average land productivity increases per annum considered possible. Assessments of Papua New Guinea's total land use potential put the area which is technically suitable for tree crops or arable agriculture at about 1.6 million acres. The Table 1 projections therefore mean that as much as 72 to 83 per cent of this stock of land resource would have to be brought into use by the end of the current decade. By the same criteria, large areas of land are considered suitable for pastoral agriculture (4.7 million acres for grazing and another 3.5 million acres for mixed farming). The planned expansion in numbers of beef cattle, which are the most important grazing animals kept for commercial purposes, means a growth rate of around 14 per cent a year, giving a total herd size of 300,000 by about 1980 . This number of cattle would require about 1.35 million acres of pasture, accounting for 29 per cent of the total land designated as suitable for grazing. Pasture requirements in the 'zero growth' economy would be only half this amount.

The production of food crops for the domestic market is currently planned to grow each year by over 8 per cent, though in our higher projections we have assumed a slightly lower rate of increase (7.1 per cent a year). If average yields per acre in market gardening do not change, then the area of land needed for this activity in 1980 in the 'medium' and 'high growth' situations would be double the acreage used in 1970.5 In the 'zero growth' projections, the market garden area would increase by little more than one-third above its 1970 level. No reliable figures for the area of Iand currently devoted to either commercial or subsistence food crop production are available, so these projected increases in land requirements cannot be expressed in terms of acreages. For non-commercial food crops the present development programs envisage increased production in non-marketed primary pro-

5 The market gardening projections do not include any increases in the rice area. Expansion of this crop on any major scale seems unlikely at present, owing mainly to technical problems. 
Table 2 Land for export tree-crops and beef cattle production: past supply and future demands

The past expansion of utilised area and planned or projected future requirements is expressed in terms of a constant percentage annual increase. The periods to which the figures relate are given beneath each growth rate.

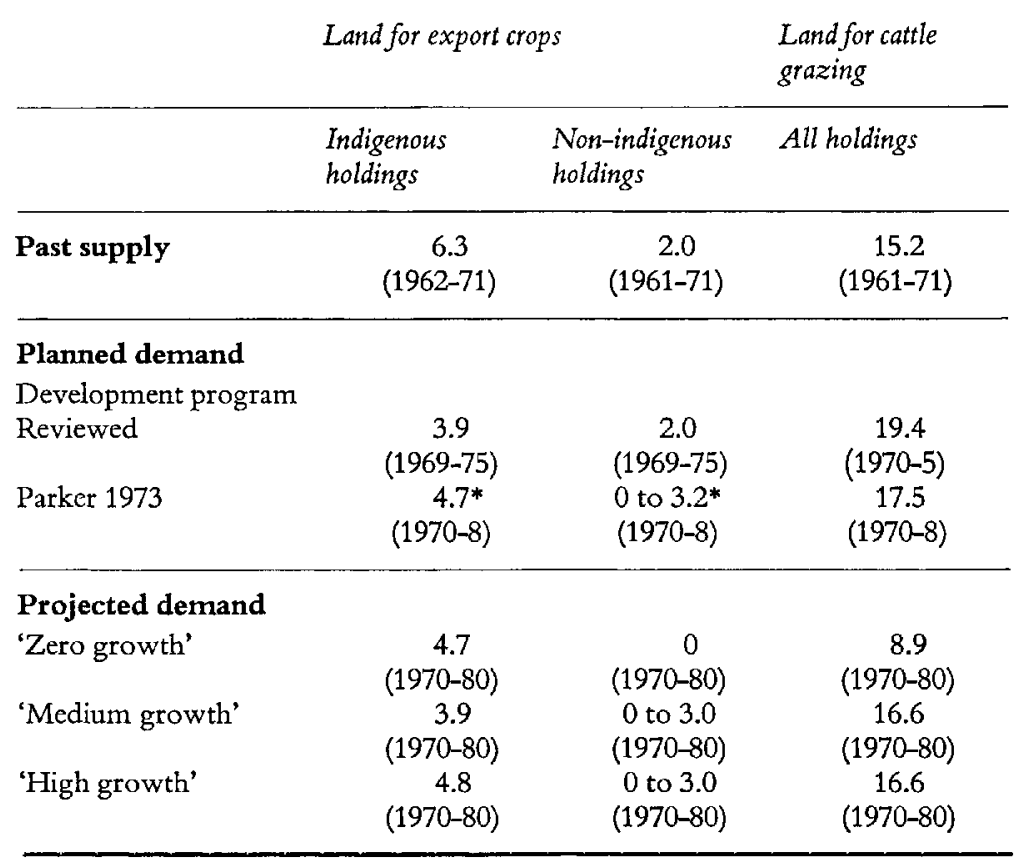

* Excludes the change in oil palm acreage.

duction at a rate of 1.8 per cent annually. If this is taken to represent subsistence production, it implies a 20 per cent expansion in the area used for subsistence gardening with current techniques between 1970 and 1980.

One way of assessing the likelihood that sufficient land could be developed agriculturally to meet the demands implied by the official plans or by our projections is to compare the rate at which land has been brought into use in the past. Such a comparison is made in Table 
2 for export crops and beef production which, apart from subsistence gardening, are the main agricultural uses of land in Papua New Guinea. The historic, planned or projected increases in land use given in Table 2 are expressed in terms of average annual growth rates, because the changes in acreages involved relate to periods of varying length.

When land is brought into cultivation farmers will first of all develop the most accessible areas and those which entail the least cost or involve the minimum of 'legal' wrangling. As increasing amounts of the fixed stock of land are used up, the effort and cost required to bring an extra acre into cultivation also increase, so the rate at which new land is made available becomes slower and slower. Eventually, the high costs of developing land mean that a proportion of land which is technically suitable for cultivation will probably never come into use. The change in acreage under export crops on smallholdings (excluding the area under coffee) during the ten years 1962-71 is consistent with such an interpretation of the process of land utilisation. Nearly twice the acreage was brought into production during the first half of this decade (about 88,000 acres) as during the second half (about 46,000 acres). Coffee was excluded from this example because, after much official enthusiasm in the earlier years for expanding the coffee area, the Administration in later years directly discouraged further plantings. ${ }^{6}$

In terms of the rate of increase in commercially developed land area, Table 2 shows that the smallholder export crop acreage is not expected to expand as rapidly in the current decade as in the previous one. Recent plans for the expatriate estate sector, on the other hand, provide for an increase in area here at the same rate as before. The latter now seems an unlikely prospect since the broad strategy for economic development in vogue when these plans were drawn up has since been displaced by one which is more sensitive to the relative shares of indigenous and non-indigenous land owners. The more realistic view is that any substantial increases in production from expatriate estates will reflect better yields rather than the use of more land.

Our higher projections and the plan targets in particular demand a

6 With the current export arrangements, indications are that further planting of coffee will again be encouraged. 
greater rate of growth in the area made available for cattle grazing than has been implied by the expansion of the cattle herd in the past. The main reason for this big increase in pastoral requirements is that an increasing proportion of the cattle will be kept on smallholdings with considerable reliance on unimproved pasture as opposed to the predominantly improved grasslands of the non-indigenous ranches.

A comparison of growth rates in land use, however, understates the dimension of the land supply problem, because the same rate of growth in later years means an absolutely greater area of land coming into productive use than in earlier years. This can be illustrated by comparing the actual past increase in the smallholder export crop area and total cattle grazing requirements with the increases in area implied by the lowest of the projected growth rates. Thus a 6.3 per cent per annum average rate of growth in the smallholder acreage meant an additional 194,000 acres being brought into use between 1962 and 1971; the much lower growth tate projected for the period 1971-80 (3.9 per cent a year) means demand for an extra 188,000 acres. Again, a 15.2 per cent growth rate in the effective grazing area during 1961-71 added an extra 239,000 acres to what was needed in 1961, whilst the 'zero growth' projection (8.9 per cent a year) means that by 1980 a further 419,000 acres would be required above the 1970 figure.

To the demand for extra land for cash-earning activities shown in Table 2 must be added the growing subsistence requirement in order to arrive at the potential demand for more land. Where requirements for land for cattle grazing, export crops, market gardening, and subsistence production compete, the conflict cannot necessarily be resolved by transferring one or more of these activities elsewhere. For example, transport costs and storage problems effectively restrict market gardening to the urban hinterlands, while ecological factors and processing and transport needs limit the areas in which export crops can be profitably grown. Resettlement schemes and 'virgin land' development have frequently been seen, in Papua New Guinea as in other countries, as a logical and relatively painless way of solving this problem of excess demand for land in particular localities. Experience elsewhere has shown that these schemes are always costly, and are 'particularly failureprone just as some people are accident-prone' (Hirschman 1963). 
The comparison with the increase in supply which was forthcoming in the past suggests that there is likely to be a gap between what is required by any of the economic development profiles considered and the amount of land which, on the basis of past performance, will become available. It is clear that, in relation to agriculture, any decision on land matters which inhibits the flow of land into productive use will make the realisation of even modest economic targets impossible. It follows that any shortfall in the supply of land below projected requirements must be compensated for by unprecedented efforts to increase yields per acre on existing holdings. This will create a myriad of problems associated with the logistical and legal apparatus needed to supply and encourage the use of new inputs in village agriculture. Since the technological transformation of agriculture which is involved has been found so difficult to bring about in many other developing countries, we feel that for a country with Papua New Guinea's existing land resources, population and agricultural technology, efforts devoted to facilitating the faster flow of land into productive use will be the better strategy to adopt.

There are of course special problems associated with urban land use. Migration into urban areas, which in Papua New Guinea represents the spontaneous movement of people, as opposed to the planned transfer in resettlement schemes, creates its own special problems.

Where there is any element of a free market, the growing pressure on a limited amount of urban land will lead to steeply rising land prices, leases and rentals. These will choke off demand and allocate land between competing uses according to ability to pay. The poorest sections of the urban community will be those least able to compete and so will be forced to accept higher densities of housing at present found only in the worst squatter settlements. So the increasing pressure on scarce land is likely to bring standards down towards those of the shanty towns that are characteristic of cities in the underdeveloped world. Higher land prices will also make it more difficult to improve the housing conditions of squatter groups, and will in general inhibit development of social amenities whose funding depends on success in the competition for a share of limited tax and municipal revenues. Another consequence of the rise in land prices is a redistribution of income in the form of windfall gains to small groups who, 
by accident of location of their villages or by successful speculations, hold land on sites marked for urban development. The only alternative which would ensure a continuous supply of land at prices which would not inhibit many important urban developments, is extensive public or municipal interest in the control of land on urban sites, with compensation for former owners at levels which reflect the value of the benefits which have been lost, such as gardening and hunting, and not at the scarcity prices which would obtain in a free market. To make this politically more acceptable even harsher terms may be necessary in acquiring for urban use land which was previously alienated to non-nationals.

In urban areas there is no alternative, shott of halting the growth of the towns, to facilitating the steady transfer of land to urban uses on a scale and at prices which will at least limit the social ill-effects of urbanisation and the redistribution of income towards a fortunate minority. The natural desire of private groups to protect their own 'rights' and profit from accidents of location must be subordinated to the needs of the whole community for rational urban development. 


\section{The psychological dimension}

\section{B. G. Burton-Bradley}

Land problems are usually seen as the product of ecological, demographic, and socio-economic pressures, but the human being, the focal point of these problems, is also under the influence of forces within himself. That the significance of these forces for land problems has so far attracted little attention is particularly surprising since the fundamental importance of a (learned or instinctive) territorial imperative is recognised in other contexts where its practical relevance is far less apparent. ${ }^{1}$

In the course of my work in Papua New Guinea, I have become aware that the indigenous person has a psychological attachment to his land transcending the purely economic and legal arrangements of the superimposed alien culture, however liberal the latter might be. I find that he may go along with the formal arrangements in order to please, but in his thinking and at a deeper level his basic attitude to what is his land remains substantially unchanged throughout life, independent of any transactions and exchanges which have taken place. His land is the place where he was born, where he was subjected to primary enculturation, where he has lived the most important aspects of his life, where the values of his cultural-linguistic group have been constantly reinforced, and where, in most instances, he may die. As he grows up he learns that it is the place where his ancestors preceded him, and to which they may return, thus giving the attachment a magico-religious sanction. It is the place where his children and his children's children will follow. At the psychological level it is clearly an extension of the concept of self.

Land matters do not constitute an invariable component of the symptomatology of people with mental disorders in Papua New Guinea, but they occur frequently enough to require reference to them as part of the formal examination. Land matters may colour and embellish

1 There is a tich biological and anthropological literature in this field; see, for instance, Alland 1972; Ardrey 1966 and Hall 1963. 
the symptoms of people with psychotic disorders, particularly those in older age groups, where they take the form of auditory hallucinations and grandiose delusions. This can constitute a considerable source of embarrassment to sons and daughters who have undergone a considerable degree of acculturation through formal education. I would certainly support the view that loss, or threat of loss, of one's land or land rights is an important psychological trauma.

This is best illustrated with some examples. Let us look at the older bachelor. It is unusual for an indigenous male to remain single. The reasons for this are clear. An unmarried older male has a marginal place in village society, no family members to assist him in co-operative labour, and no one to look after him in sickness or old age. He is a man without a niche. Accordingly, there must be some special reason why he is single, and why he has reached this position. He may have been working for long periods of time in the various larger towns on the coast and have lost his former pattern of social relationships with his own people. When he retires to his village, which is his land as he defines it, he may be rejected, and this has led to suicide.

From the Papuan and New Guinean point of view, there is no place in indigenous cultural systems for a person of mixed-race. The village people may resent the mixed-race man's allegedly superior attitude when he visits the village of his indigenous mother, and they have the greatest contempt for anyone who does not own property in land and who is not rooted in his own land and people. The mixed-race man by virtue of the descent and customary machinery of inheriting land is a landless person, and the lack of a certain and satisfying identity that derives from this has also played its part in those rare cases of suicide that occur among this group.

Some other items of clinical origin are pertinent to the psychology of land attitudes. Medical officers often find it difficult to persuade elderly people to enter hospital, as they say they do not want to die away from their own land and people. This is particularly prominent in some villages on the Sepik River.

The following case illustrates the intense attachment of a sick person to his land, the feat of strength in fleeing to it, and the assignment of magico-religious attributes to the land as the ultimate source of paradise. A young male Orokaivan in his mid-twenties from 
the Northern District of Papua was temporarily employed in a factory in Port Moresby. His supervisor introduced a new method of work to reduce wastage. The young man did not co-operate in the change and was told that he would be dismissed because of this. He then attacked his supervisor and bit him on the buttock. He would not release the bite until another employee forced a stick between the teeth. It was about this time that the spirit of his dead grandfather appeared and told him to go back to his own land. This he did and commenced to dig a deep hole there. He explained later that in due course he would come to a big snake with skin like a white man, and that the snake would lead him to paradise. While there he would find a thousand dollars, a considerable sum for him. The hole ended up about twenty feet deep. He was admitted to a mental hospital and then absconded back to his own land on foot, a distance of some fifty miles. He resumed the digging, and killed a woman with an axe because she had laughed at his efforts.

In some areas it is the rule for a man to build his house in that part of the village nearest to the food garden that he intends to cultivate. A man from the Morobe District followed this rule in the ordinary course of events. But as he was suffering from schizophrenia he had pathological needs as well. Reinforcing his attachment, he built a fence around the house and land, a rather incongruous structure out of harmony with the rest of the surroundings. The result from his garden were not very satisfactory, and this led to an upsurge in cargotype thinking. He killed his child by dashing its head against a rock, saying that the infant was blocking the road to cargo, and that what he needed was a white baby to ensure that the results were fruitful.

What is the importance of the territorial imperative for women? In general a woman spends more time on the land in gardening than a man. On coming to the larger towns she lacks the psychological satisfaction in growing things which she had before. She has more to lose in this regard than the men. The uneducated woman becomes insecure and completely dependent on a male, whether husband, brother, or father, for the survival of herself and her children.

A Chimbu woman after arrival in Port Moresby became homesick and unhappy. She did not eat, lost weight, refused to learn Pidgin, quarrelled with her husband and his relatives, and went to hospital 
many times with allegedly minor complaints which were clearly categorised as anorexia nervosa, that is, severe loss of appetite due to psychological causes. She said 'I have no land here', 'I have no sweet potatoes', and 'Port Moresby is no good'. Her health was seriously endangered. An arrangement was made for her return to Chimbu, following which she made a complete recovery confirmed by medical examination.

A Daru woman commenced a business in Port Moresby. She immediately wished to abandon it. She said 'I was brought up on a Mission and therefore I have no land. What am I going to do in my old age?' Her constant preoccupation is with the prospect of buying land in Daru.

An educated Chimbu woman and her family had lived in Port Moresby for some time. They were delighted when they heard that a cousin had married a man in the Western Highlands and that the latter had promised them a present of land. The response. was more than one would expect in their situation.

It is to be noted, also, that the clan or lineage land is part of life-in fact it sustains life. The matrilineal land's produce is taken to a woman by her brother in the Trobriands as he is responsible for supporting her even though she lives elsewhere. Transgression of such a custom can lead to psychological disturbance. In short, psychological factors and the territorial imperative are of at least equal importance to women compared to men, and in some cases even greater.

Land borders are often well known to all concerned and established over long periods of time. An individual's land rights are also often well defined by specific criteria, even in the case of the adopted person as applies in various parts of the Highlands where looseness of social structure may be the order of the day. Here a man may have a wide possibility for individual choice with respect to group affiliation. Nevertheless he usually has a clear idea of what is his, as a jointowner with the group, and would tend to take it seriously. Others would also have knowledge of the nature of his rights, which have been secured through the exercise of his obligations, confirmed by work in the common interest over a number of years.

Thus a man killed his adopted daughter, after she left him and returned to her original biological parents who lived in another area. 
As he saw it, he had paid for her clothing and education over a period of eight years, and had opened up a bank account in her name. She had not lived up to the obligation of helping him and his wife in the food garden. In his view she had rights and obligations which could be exercised only on his land.

In another instance a man was told by his father that he no longer had land rights because he had married into another clan. He was told to get off the land and take his trade store with him and move to the land of his wife. As he would not be working with his father in the future, he now had no further rights. This resulted in considerable mental suffering, and the precipitation of a mental illness requiring psychiatric treatment.

In yet another instance conflict arose over land unused for a whole generation by one group. A second group occupied the land and exploited it fully. When the crops were ready, the first group destroyed them, which resulted in open warfare and sustained hostility for many years.

Psychological factors will certainly influence the ways in which land in Papua New Guinea is used and owned in the future. The question is merely, what can or should be done about it? First of all, there is need for recognition of the existence of these factors by all concerned, for active research in this area, and for identification of those specifically psychological problems which may prove crucial for the success of total development strategies. All too of ten in the past psychological aspects of land questions have received far too little attention, though if there is one element common to the multidimensional nature of all land problems, it is certainly a psychological one. In the pursuit of any particular goal such as, for example, the restoration of a basic title to the original owners similar to or consistent with that in pre-European times, the employment of psychological principles of attitude change would be necessary for total effectiveness.

There is also clear evidence that psychological factors play an important component part in the responses of given individuals to the transgression of customary land codes as they define them. Land disputes can be highly emotive matters, with cooling off periods at times clearly desirable. Not all will react in the same way to an identical situation. For these reasons, I believe, those officers who are 
responsible for investigating and appraising these concerns should have, as part of their training, a good grounding in those special areas of psychology pertinent to their work. These would include dynamic psychology and a clear understanding of unconscious forces, the nature of mob pressures, and the psychology of industrial disputes which, although dealing with other affairs, is governed by the same range of mechanisms.

But the multifactorial nature of the forces binding man to his land must be recognised in a far more general way. Psychological ties are reinforced by the everyday affairs of the people. Ceremonial activities are central to the life of many Papua New Guinean cultures, as are many artistic and recreational spheres of action. Traditional plastic and graphic art forms are among the best in the world. All give colour and dignity to what might be in some instances a very drab existence. These sentimental bonds are intimately wrapped up with the land on which life is lived. Land tenure and land usage is almost invariably strengthened by magico-religious sanctions. Hogbin (1939) has pointed out the intense love of the indigenous people for the land, how they wish to have the earth on their hands to the end, how when dying they wish to see their gardens for the last time and to be buried in them, and how the culture heroes approached the land in the same way. Thus there is preternatural justification for psychological attachments as well.

It should also be noted that much legal behaviour has important psychological consequences, often of an unexpected nature. At one time the law was considered to be a passive instrument designed solely to lay down the rules of behaviour that arose from the persistent and established patterns of conduct in a society. It was a codification procedure, a reflection of customs only, it was said, and one could not legislate people's behaviour. Recently, however, more emphasis is being placed on the law as playing its part as an agency of behaviour modification. As an independent psychological force it can consolidate and integrate normative behaviour and stimulate respect for values implicit within the law. This is certainly true in respect of some of the legislation enacted over the past decade in this country. Outstanding examples are the Discriminatory Practices Ordinance 1963 and the Native Customs (Recognition) Ordinance 1963. Quite apart from their 
codification functions the former has contributed to the reduction of traumatic interactions among peoples of all races, and the latter to the promotion of more healthy interpersonal relationships and the facilitation of communication and understanding. The archaic Insanity Ordinance drafted at the turn of the century has been replaced by the Mental Disorders and Treatment Ordinance 1960 in which the moral and legal rights of the individual patient, including land rights, are ensured and his personal liberty protected. Such legislation undoubtedly induces respect and has unconscious educational functions. The psychological principles emanating from these Ordinances could well be kept in mind in the drafting of future land laws.

Many land questions demand anthropological answers, including those coming under the heading of psychological anthropology which covers the entire area of affect, that is, how human beings feel about each other and how deficiency in permanent human relations comes about (see Hsu 1973). To what extent do we draw upon this expertise, and how effective has it been up till now? How many anthropologists are there in government employment compared with other developing countries, particularly the American Trust Territories? How distinguished is the post of government anthropologist? These are some of the many questions that arise in relation to a valuable and sorely needed skill in real life situations. It is to be noted that anthropologists are in Papua New Guinea for their own reasons, and may not wish to divulge their research findings, at least for some considerable time. They may claim they would not be given intellectual freedom, and this may be so, although this view could well be exaggerated, for many other professional groups, lawyers, physicians, architects, and engineers in government have considerable intellectual freedom. Two distinguished government anthropologists, F. E. Williams and Charles Julius, were not restricted in this way and made tremendous contributions of sterling value to the community. Clearly, more should be done in the training of applied anthropologists and their recruitment in adequate numbers. The types that are needed are those oriented to specific fields, for example land issues rather than particular societies, which is the general trend.

The fundamental importance of man's attachment to his land cannot be denied. It seems to me high time that the situational logic is 
taken into account, and the model of superimposed law strengthened to bear at least some resemblance to Papuan and New Guinean thinking, if it is to enjoy a greater level of acceptability. I would think that the recognition of ultimate ownership would have a countervailing effect, as it is built from the ground upwards, and is not a foreign system imposed from above and originally designed for other purposes. By this I mean that the traditional rights of individuals and groups to land should be recognised as ultimate ownership and that feudal ideas, such as the basic title of the Crown to all land, should be abandoned. I would go even further, and recognise the ultimate inalienability of land, so that the basic title would always remain with its traditional owners. This raises problems for the settlers from over-populated areas who have to take up land to which they have no traditional ties, although long-term leases could well meet their psychological needs for identity and satisfaction, for they would be well aware of the nature of their title. But it is clearly essential for the full psychological stature and dignity of Papua $\mathrm{New}$ Guineans as a new nation that at least the basic title to land acquired by foreigners is returned to its original owners. 


\section{The price of progress}

\section{N. E. Olewale}

The basic fact of life for a man living in a traditional village was his dependence on the group. It was quite impossible for him to exist on his own efforts alone. He needed help to build his house, to make his garden, to make his canoe, and even to find a wife. Above all, he needed help in defending himself from the ever-present danger of sudden attack.

Perhaps if there had been some form of money which could have been used to buy services as we needed them, we could have developed a more individualistic form of society, but we had no form of money as European people understand the word. In many parts of the Pacific and in some parts of Papua New Guinea there was a form of shell money which even today is still used in traditional ceremonies, but this 'money' was almost always an exchange object for ritual purposes rather than a token of value which could be used in a system of daily exchange of commodities. For practical economic purposes we had no money. If a man acquired through hard work or good luck a larger than average crop of vegetables or a very large haul of fish, this could not be stored and used at some future time. The only way for him to benefit from it was to distribute this perishable produce among his friends and relatives and so create a debt to be repaid by these people at some future date. Our medium of exchange therefore became a system of obligations. In fact we ran a very complicated and precise system of credit. This of course increased the individual's dependence on the rest of the group. Not only did he need their assistance for certain essential projects such as those already mentioned, but he also needed them as recipients of his surplus produce so that they could become debtors and give him 'money in the bank'.

It was most unlikely that any individual would accumulate a store of material possessions much larger than the average. Everybody tended to need the same sort of possessions because all tended to do the same work. Once equipped with a full set of tools, there is not very much point acquiring more and more sets of these tools. The acquisition and 
utilisation of certain ceremonial or ornamental objects of ten became a more or less endless activity, but nowhere in Papua New Guinea was there a traditional society in which it was possible for a man to live by means of his wealth alone. Individual ownership tended to be restricted to objects which a man either made himself or acquired by trade through his own efforts. Obviously, nobody could 'make' land. It continued in existence forever, whereas the person using the land existed merely for the few years of his lifetime. How could a man own something which would continue to exist long after he himself was dead? To the traditional society it was obvious that man merely used the land and that the ownership of land belonged to the group as a whole and not to any individual member. It is this fact which has caused so much trouble in Papua New Guinea in recent years and which will probably cause a great deal more trouble in the future.

Our traditional society was adequate for our situation. We were a static community living more or less in balance with nature and the population groups around us. I am not suggesting that our customs are superior or inferior to present trends, I am merely saying that they were adequate to our needs. About a hundred years ago the white man arrived, with fatal effect on our state of balance. His technology was amazing and obviously quite superior to ours. Because he was technologically superior, he quite naturally assumed he was in every way superior, and we accepted him at his own value. We accepted his laws, his religion, and his criticism of our life, and we believed him to be correct. We believed him to be infallible. It is only now that we realise that in addition to the technological achievements which he has given us, he has also presented us with problems which he himself does not know how to solve in his own country. Our traditional society was admittedly static but at least it was in a state of balance. A man knew what to ask of and what to expect from society around him. The new system brought to us by the white man was the same as the system which exists in his own country. It is not in a state of balance. It depends on a continual growth which must never stop. If his society is to remain happy and healthy, it must never slow down. It may even be necessary for the rate of growth to increase each year. Such an ever-increasing rate of growth and change is completely impossible to reconcile with our traditional form of existence. 
One of the doubtful benefits the white man brought with him was an awareness of our own poverty. It is true that in material terms we are not and have never been rich people. But at least traditional society shared equally whatever wealth it did possess. This was because everybody had more or less equal shares in the land which was the people's only real wealth. With only a few exceptions this communal ownership of land has been maintained all over Papua New Guinea so that, although we are now aware that we are, as a race, paupers, at least we are all roughly equal in our poverty and no man should starve in this country. This is the one essential aspect of our traditional life which we have not yet given up. It is precisely this essential aspect which the proposed new land legislation introduced into the House of Assembly in 1971 would have changed forever.

The main reason for changing our traditional land laws is to open up our land for economic development. This term, economic development, is one with which the people of this country are very familiar. Practically everybody who has heard English spoken has heard this expression, but very few realise its full implications. Very few people, white or brown, completely understand what economic development will do to a traditional society. Economic development is universally considered to be a good thing and it is not always realised that, like everything else, one must pay a price for it. I do not think that my people realise at all what will be the price of the changes which economic development will bring. There has never been a large measure of economic development in any country without equally large and often unhappy changes spreading through the greater part of its population. From the time of the English Industrial Revolution right up to the present day, any form of economic development has meant some sort of change in land holdings. This has always resulted in large numbers of the people being thrown off their land so that other people could use it more efficiently. The methods used to get them off their land have varied, but the results have always been the same-a landless group of people forced to work for wages to keep on living. This will be something new and frightening for Papua New Guinea.

The process of our development cannot be turned back. Because we are part of an expanding and developing world it should not be turned back. But at least we can make sure that the changes brought 
into the lives of the people will do them as little harm as possible. Because individual ownership of land will completely destroy the main prop of our traditional society, it is a change that must be regarded with extreme distrust. It is a change that may not even be necessary. Most of the people of Papua New Guinea still live in villages. They still depend heavily on family groups. This pattern of traditional life has not yet changed. All over the country, where land is concerned, our traditions are almost all strongly communal. This makes it very difficult for anybody to take land away from us.

From the earliest days the Administration of this country has claimed to protect native ownership of land. Where it has not clashed with Administration land requirements this has generally been done. But now that Australia wishes to leave Papua New Guinea, it is very anxious to see the country paying its own way. To do this it is necessary to build up exports to increase the size of our cash economy, and in general to get everybody to produce more. Land for commercial production is in short supply, and as long as we have communal ownership of land as the almost universal rule, it will continue to be in short supply. It is a very much more difficult task to persuade a group of several dozen people that they all want to sell a particular piece of land than it is to persuade an individual owner. For one thing the returns from the sale of the land are so much greater for an individual. For another, in any group of owners varying in age from new-born infants to white-headed old grandfathers, there are always some people who will flatly refuse to consider selling under any circumstances, no matter how good the deal offered. Negotiations with groups for a sale of land are always very long drawn out and complicated affairs.

If you consider that land is a commodity to be bought and sold or, in economic terms, a factor of production to be used for the best possible advantage, it is obvious that group ownership is an obstacle to efficient use and easy transfer of land. In the interests of productivity, therefore, group ownership should go. However, to my people land is more than a factor of production. It is more than an object to be sold. It has been in the past our sole guarantee of existence. If land is to be taken from the people it will be necessary for them to find another way to exist. I think it is fair to say that this fact is simply not understood by the vast majority of people outside Papua 
New Guinea, or at least it is not fully appreciated. Perhaps it is this idea which makes so many of the older people within the village community so hostile to the transfer of land.

The younger people who have been to school tend to see their future as being in the towns. It is a fact that they are probably drifting away from the villages and moving to the urban areas. Their association with the traditional way of life is now not so strong. Perhaps in this lies the solution to the problem. Perhaps the problem is not simply whether we should have communal ownership or individual ownership of land; perhaps the real nature of the problem is how quickly the transition should take place. But whether the change takes place quickly, all at once, or whether it takes place slowly, piece by piece over a generation, the result must be the creation of groups of people who are landless and who must work for others if they are to live.

This is very frightening to a traditional man. Perhaps it would not be quite so frightening if this country had the same system of social insurance and social service benefits as the Australian people have, but our Government cannot afford this and will not be able to afford it for a long time to come. The traditional village looked after all its people-the old people, the sick people, and those generally unable to look after themselves. The new individualistic society will not do this.

In our traditional society people depended on their gardens for most of their food and for a great deal of their wealth. Our men who obtain individual title to blocks of land and who will now set themselves up as farmers growing export crops will be entirely on their own. They will be producing for a market that they cannot see and cannot imagine. They will receive prices for their produce over which they will have no control. In most other parts of the world, the farmers are subsidised by the government in some way or another. We have no industrial sector in our economy which can help our farmers in this way. Our people cannot yet pay taxes high enough to pay subsidies to rural producers as well as the general costs of running the country; in fact their taxes will for many years not even be sufficient for the latter. There will therefore be a very good chance indeed that our individual farmer designed on the Australian pattern will leave 
his farm because he does not have sufficient protection against the normal fluctuations in prices of tropical crops on the world market.

If you look at a map of any Australian shire you will see that a surprisingly large number of the blocks of land are owned by banks. If individual title is introduced into this country the same thing will happen here. If a man wants to borrow money from the bank he will need to own land which he can use as collateral for the loan. It must be expected that quite a large number of our farmers will lose their land over the years, not only because of their own shortcomings as farmers but because they are producing tropical crops which are notoriously shaky on the world market. In order to recover their loans the banks will sell this land to anybody who has the money to pay for it and outsiders will move onto traditional village land. Village people will not understand this process because to most people in Papua New Guinea no man has the right to dispose of land except in certain traditionally accepted circumstances. The new laws will not satisfy these requirements and therefore the people will not believe that the land is legally alienated from them. There will be complete confusion; trouble and fighting will probably destroy any economic development which has taken place on the land and the whole process will have been a waste of time, effort, and money. Unfortunately, the most likely lasting result from all this will be that the traditional village life will be destroyed forever.

The main object behind moves to introduce individual title is to change our traditional tenure system so that it fits in with the requitements of alien institutions, like banks, which have been brought into this country. To my knowledge no attempt has been made to change the methods of the alien institutions so that they fit into the traditional systems of the people. There has been a great deal of discussion on the problems related to extending credit to indigenous people in this country, especially to people in rural areas, but it has always seemed to me that the problems being talked about were the problems of fitting our traditional systems into the tried and true business methods of the Western world rather than the problems of adapting these Western business methods to fit into the traditional systems. The people who are so busy trying to adapt our customs seem to forget that a law will work only if the people accept it. 
With regard to land, the people in general will need to be in favour of any law changing the traditional pattern before any government could seriously consider passing it. In fact, the people knew nothing of the laws proposed in 1971, except what they had read in the newspapers, and there was no real campaign to explain the proposed changes to the people or to find out their opinions. In a society such as ours it is not sufficient to publish proposed new laws in newspapers and to invite comment and criticism. To the average man in the village the world outside that village is very vague and the way in which it affects life in the village is not very clearly understood. No amount of discussion of the proposed change is going to convince the man in the village that any impact will be made on his own life until that impact actually takes place.

If you want to convince the village man that a proposed new change is going to affect him you must undertake an exercise of the size and scope conducted by the Constitutional Development Committee. This was a very lengthy and expensive public relations exercise which was undertaken to give the greatest possible number of people the impression that they were helping to decide the course of political development in this country. The proposed changes in the land laws were far more important to the people than anything they were asked to decide concerning constitutional development, yet no attempt was made to consult them. No Papuan or New Guinean was included in the working party which toured Kenya to examine how the new land tenure system was working there. The new land laws proposed for Papua New Guinea drew very heavily on the methods adopted in Kenya, but there was no Papuan or New Guinean on the interdepartmental co-ordinating committee which considered the recommendations of the working party after its Kenyan tour. It is also disturbing to note that there are certain widely known deficiencies in the Kenyan system. I wonder what made the committee think the system would work any better in Papua New Guinea than it does in Kenya.

Every Papuan and New Guinean considers himself a far greater expert on the workings of the traditional land laws than any outsider, therefore in the eyes of the people the new laws were drawn up by men who do not understand out traditional laws. Nothing but trouble 
can result from this. It has been said that the proposed new laws will not change the ownership of land from one person to another or to the Administration. It has been said that the new law will simply give the owner or owners a better title for their land and therefore more security for development. It is a surprise to the owners of traditional land which has been held for hundreds of years that it is possible to obtain a better title to the land. Many of them will certainly query that the new titles are in any way better than their traditional claim to ownership. Many will in fact believe that the new titles are very bad because they will strike at the basic foundation of village life in this country.

This word 'security' also needs to be looked at. Is it implied that the traditional titles are insecure? In this sense the word security is used in the way a bank manager would use it, which brings us back to the basic fear of all village people. The new titles are nothing but a way of taking the traditional family land away from the family. To most people this is the most frightening thing which can be imagined. The people would rather develop a system of family liability for individual debts than permit their land to be used as security for those debts, and ultimately as payment for those debts.

The effect that the new laws would have on the village is of course only part of the question. It is by no means certain that the laws would actually work. What a tragedy it would be if our traditions were destroyed by a new system which turned out to be unworkable. There is already considerable disagreement as to whether the new land laws are in fact working well in Kenya. Not everybody agrees that the economic development that has taken place there is the result of the change in land tenure systems. Some people claim that this development would have taken place anyhow, due to entirely different factors. It has even been shown that one area which has one of the highest rates of economic development in Kenya has had less to do with the new land laws than any other area. However, perhaps the main objection seems to be that after a while changes in ownership are simply not recorded. I was in Kenya in 1970 and while there I looked at the new system. I saw many small land owners with their certificates of ownership, and they told me how important these certificates were to them. But I also heard that many blocks of ground have changed hands without the change of ownership being registered. This sort of 
thing could result in even worse chaos than the oldest ownership disputes under our own traditional laws. The new system would need a large amount of time, money, and manpower to implement. Can we afford this? Will the returns from any extra development resulting directly from these new land laws be worth the cost of implementing those laws? If the job is to be done at all, it must be done thoroughly. If it is not done thoroughly, things will be much worse than before.

One thing in particular worries me greatly. It is all very well to change our customary land laws, but what about all the other customary social arrangements which depend on those laws? Has any thought been given to looking after the people who are going to be disinherited? Have any new laws been considered to provide for them? Our old customs were arranged in such a way that no widow, orphan, or old person ever had to worry about becoming a pauper. The social impact of these new laws is so vast that it is doubtful if any Australian who has not been closely associated with Papua New Guinea could ever begin to understand them. At least the new laws will provide a rich field of study for anthropologists for a good many years ahead. I doubt if the unfortunate people whom they will be studying will find much consolation in this. 


\title{
6 The cultural squeeze
}

\author{
D. M. Fenbury
}

On 16 December 1972 Michael Somare, Chief Minister of Papua New Guinea, outlined the decisions reached by his Cabinet (during what he described as 'a historic week') on the strategy of an overall 'improvement program' that would be launched in July 1973. He emphasised that the new economic strategy's central themes were 'decentralisation, rural improvement, equitable distribution of incomes and self-reliance -they are directed at improving the lives of our people'. After pointing out that the plan sought a rapid increase in the proportion of the economy under indigenous control, a more equal distribution of economic benefits, more agricultural development at village level, and more involvement of local councils and area authorities in local development, the Chief Minister added: 'there will be an emphasis on small-scale artisan, service and business activity, relying where possible on typically Papua New Guinean forms of organisation. . . '

It is this last sentence, perhaps, that betrays the wistfully wishful thinking of Niugini's ${ }^{1}$ burgeoning nationalists. Predictably enough, the urges of Niuginian politicians to shy away from appearing as brownskinned Australians, and to seek traditional Melanesian approaches to solving non-traditional Melanesian problems, have been strengthened by the heady brew of rapid political evolution. But, equally predictably, these ambitions continue to be largely frustrated. While the validity of the blending of cultures thesis, once so dear to the hearts of some anthropologists and administrators, has been largely discredited by events, it is still, in confused and confusing ways, an article of faith with the evolving Niuginian villager. For this reason alone, few Niuginian bureaucrats, and fewer politicians, are as yet prepared to evaluate the probable cumulative effects of increasing population and economic development on a wide range of ancient subsistence-economy mores.

1 For convenience the terms 'Niugini' and 'Niuginian' have been used when reference is made to Papua New Guinea and its indigenous population. 
It is not necessarily significant that the Chief Minister's long statement avoided mentioning that radical changes in indigenous systems of land tenure, land use, and land inheritance would be prerequisites to any durable improvements in the lot of the average Niuginian villager. In fact, it is possible that $\mathrm{Mr}$ Somare, like many other educated Niuginians, may not consider that these evolutionary problems are as yet urgent, or that they already exist. But even if the Chief Minister happens to be personally convinced that customary tenures don't make for sound commercial farming, he would be also clearly aware that in the Niugini situation of 1973 there is no political mileage to be gained from peddling this issue.

In February 1971, some of the problems attending progress in Niuginian tribal societies were outlined by the present writer in the following terms:

For all the wishful thinking and rationalisations, it seems as clear as anything is clear in these magic isles that when an erstwhile static tribal society of subsistence gardeners becomes involved with the medicine, education, commerce, technology and philosophies of 20th century industrialised civilisation, its pre-contact economic, social and political structure and usages-in fact, most of the tribe's traditional values-become progressively anachronistic.

Planners who should know better are still apparently kidding themselves that village living standards can be permanently raised by superimposing rather inefficient cash-cropping onto land tenure and land-use systems evolved for primitive subsistence needs. It even seems to work moderately well for a while-providing you avoid analysing per capita returns-until the dragon's teeth of increasing population, increasing individualism and increasing needs start to tear the facade apart (1971: 40).

From the generalist administrator's viewpoint, the last two sentences of that excerpt summarise a persistent delusion that afflicts both the evolving villager and many of his agricultural mentors. But even in those few area situations where government officials have made warning noises over long periods, the Niuginian has not been prepared to change course. There seem to be certain magico-religious thickets in the hypothetical 'average' Niuginian villager's philosophy, where land 
concepts are entwined with what he perceives as corner-posts in his tribal society's structure. As the villager seems to feel this situation (I use the term 'feel' advisedly), traditional land rights constitute both gnarled roots stretching back from these corner-posts to remote but still potent ancestors, and new tendrils of social security stretching forward to his children's children. Even when faced daily with stark evidence that no more ancestral land is available, he is still both unwilling and unable to appreciate that as his community increases in size those sacred roots and shoots must wither.

Niuginians are not devotees of proverbs or abstract thinking, but most-including those in the more economically advanced areaswould endorse all that is implied in the much-quoted saying first attributed to an old Nigerian chief: 'Land belongs to a vast family of which many are dead, few are living and countless members are still unborn.'

Much of the political and administrative difficulty of effecting land tenure reforms derives from the awkward fact that until the culture contact process attains a certain momentum, the Nigerian adage is valid. Rowton Simpson has commented that while the process of individualising customary tenures may be initially stimulated and subsequently accelerated or 'brought on' by government, it cannot be kept too clearly in mind that

a premature application of the obstetrical forceps, however well intentioned, may lead to stillbirth. There have been many abortive attempts in Kenya in the past ten years which have cost much in time, effort and money. Papua-New Guinea can benefit from this experience (1971: 5).

It verges on the trite to state that in 1973 the rural indigenous communities who comprise most of Papua New Guinea's 2.5 million population have been exposed to widely varying intensities of industrial civilisation influence for periods varying from less than a year to more than a century. It is, however, scarcely an exaggeration to add that the evolutionary gap between, say, the Tolai of New Britain and the Huli of the Southern Highlands-in most aspects of their material cultures-is comparable to that between Sydneysiders and the Arunta west of Alice Springs. The present tendency is for the gap to widen. 
Between these extremes are innumerable gradations with varying tempos of culture contact.

Among the implications of this frequently forgotten diversity of the Niugini tribal scene is that while the needs for radical changes in land tenure and farming methods may have been urgent among the Tolai for forty years, the first evolutionary symptoms of any such needs may not yet be apparent in Huli society at all. The economic geographer may be able to predict, with morbid certainty, what is likely to happen to Huli farmers as population increases and acculturation gathers momentum. He can do little to obviate such developments.

In 1973 the hypothetical 'average' middle-aged Tolai farmer is probably very far from being content. But he is still not prepared to accept reforms that he fears would destroy Tolai society. He has achieved some status and perhaps owns a one-fourth share in a new utility truck bought on time payment. He is dimly aware that his income is not meeting his family's increasing needs. He has also observed that his land's annual yields of coconuts and bananas seem to be decreasing, but he regards the use of fertiliser and insecticides, as practised on some European plantations, as a waste of money.

He yearns for secure title to a larger portion of his vunatarai (matriclan) land, and hopes that when he dies his biological family will be strong enough to reject the claims of his sister's children, defy the lualua (clan leader), and retain the cocoa grove that they helped him to plant. He and his brother have already had a long series of altercations with other kinsmen over the usufruct rights to small parcels of coconut plantation, with mutual accusations that custom had been flouted, and threats and counter-threats of court action. He believes passionately that his mounting financial problems have their roots in past white trickery over guns and land deals with his grandparents, and current European manipulations of commodity prices. By comparative Niuginian standards he is well off. He eats meat more regularly than most of his countrymen. He likes drinking beer and talking local politics; but basically he is little better informed than is his primitive subsistence-gardening Huli contemporary regarding the actual character of the new forces impinging on Niuginian society. He dimly realises that the land tenure and land use customs of his ancestors are no longer really workable, but he is quite unable to think his way 
out of the cultural squeeze. He tends to confuse economic causes and effects. The only cure he can suggest for his troubles is to get more land.

This is the common dilemma of tribal cash-croppers. The desire to move towards a system of individual ownership and testamentary disposition of improved land is diluted by years of conditioning as members of a lineage organisation. In May 1962 Charles Julius, former Government Anthropologist to the Papua New Guinea Administration, commented on the Tolai land situation then prevailing in the following terms:

Even those who express a desire for change in the system of land rights frequently show nervousness concerning the possible effect on the lineage organisation, and a certain timidity in bringing themselves to consider the actual details involved in a change of the system. The more responsible section of the Tolai community realises how much of social discipline, order and security has depended on the lineage and general kinship organisation, and has seen the results in disorder and insecurity arising from increasing individual ignoring of lineage duties and obligations. This has led to uncertainty concerning land right changes, even among those most conscious of the need for change.

In 1973, only an ill informed traditionalist could dispute that the continuing validity of the Nigerian adage quoted earlier is dependent upon the ability of tribal society to retain its salient pre-contact social characteristics. The historical record strongly suggests that primitive tribal society quickly loses most of its primitive virtues under the pressures of increasing population, increasing economic development, and increasing individualism. Among the early casualties are forms of social security based on customary land tenure arrangements. As Rowton Simpson commented:

Individualisation of tenure also precludes the operation of the social security system which assures every member of the landholding group, no matter how old or how long absent, some share of the group land whenever he requires it for his own subsistence. But such a system depends on a plentiful supply of land and it can no 
longer operate effectively when population increases to the extent that the land is fully utilised. Another form of social security must then be arranged (as in Europe), and anything which ensures more production from the land-even perhaps a reform of customary tenure-must contribute more to the common good than a system which militates against good land use (1971: 5-6).

In a letter on the Tolai Cocoa Project published in the South Pacific Post in May 1958, the present writer commented that the scheme

was necessarily imposed on a highly messy pattern of customary land tenure which had been crumbling for more than 40 years. The Tolais . . may be nearer the summit of their prosperity than they suspect. Within 10-15 years, unless other action is taken, the increasing pressure of their population on their land resources will lower their per capita incomes to poverty level-this at about the time when increased education and allied processes have conditioned them into expecting a steadily rising standard of living. . . .

The major lessons of the Tolai scheme strongly suggest that future plans for native economic development, to be sound in long range terms, must be based on the following:- Tenure control of any areas planted with tree crops must be removed from customary influences right at the beginning. The aim must be to achieve a series of indivisible, individual (or biological family) holdings, each an economic area, and with sale or mortgage subject to scrutiny. Whether tenure control is exercised through the Administration or local authorities is of subordinate importance to my present argument. Low-grade peasant farming is 'out'.

I believe that the approach to individualisation of tenures, limited to tree crops, advocated in this letter of 1958 , is still valid in principle, but probably no longer feasible in the more developed tribal areas. Without regard here to the physical and social problems inherent in a complete swing away from traditional farming methods, my current assessment is that the concept of wholly individual tenures is not compatible with existing Niuginian work attitudes and the reciprocity involved in village life. A keen awareness prevails of the ancient adage that many hands make light work. There is an almost mystic belief, 
possibly derived in part from misinterpreted observations of the operations of European commercial concerns, that 'company work'-a Melanesian Pidgin phrase denoting group effort with sharing of proceeds-somehow yields advantages disproportionately greater than the total efforts of the partaking individuals. Repeated experiences to the contrary, culminating in bitter litigation, never seem to shake this belief. With this, there is little realisation that in the long run the economic advancement of a community is largely dependent upon the amount of per capita production, and that to increase economic production significantly means specialisation of labour and drastic reduction of the time spent on social obligations. By and large, wefts of 'cargo cult' attitudes are still clearly discernible in Niuginian economic thinking, including that of the relatively advanced Tolai.

In the early 1950s, a series of spot analyses of how the average Tolai villager spends his time were carried out by district officials concerned with the Tolai local government councils. While not sufficiently methodical to warrant scientific status, they yielded some disconcerting results. At that time, apart from morning and evening daily services, at least one day per week, apart from Sunday, was devoted to 'church wotk'. On average another two to three days per month were set aside for special religious occasions. One day per week was regarded as being devoted to communal public works such as village cleaning and road maintenance. Attendance at funeral feasts, wedding feasts, post-natal celebrations, visits to relatives and the like, as well as the preparation for these occasions-and the ensuing recuperative period-averaged out at one day per week. Other activities included subsistence gardening (less time-consuming with the now largely banana-cultivating Tolai than with other groups), fishing (coastal villages only), house repairing, going to market on Saturdays, etc. The crude official assessment, endorsed by Tolai leaders, was that the average adult Tolai 'economic unit' did not devote more than nine days per month to economic production, that is to labour directly concerned with earning cash.

In traditional village society there is a seasonal rhythm of activities. Spurts of intensive labour on garden clearing or house building, during which fourteen or more hours may be worked at a stretch, are usually followed by intervals of relative inactivity, devoted to feasting, dancing, 
or sheer indolence. This ingrained fondness for 'target work'-a fact well known to plantation managers-is reflected in the current Niuginian approach to home economic production. In so far as commercial agriculture in the tropics involves year-round continuity of production to a greater degree than do most forms of temperate zone farming, it constitutes an important factor in any consideration of individual holdings. In village copra production the collection, cutting, and drying is normally carried out in periodic bursts, the nuts being allowed to accumulate during the intervals.

Admittedly, in most communities the number of palms is insufficient to support constant processing; but even where sufficient raw material is available, as in the Birar section of Kokopo, the growers are apparently disinclined to attempt maximum output. A Tolai leader recently informed the writer that groups from other Tolai communities still regularly spend intervals at Birar villages, purchasing 'surplus' nuts at a low figure and processing them on the site. Even with the Tolai, elementary education in the economics of commercial farming from the industrial civilisation viewpoint is still at a low level. A cocoa grower is still quite capable of leaving his ripening pods to sprout whilst he engages in a six weeks' tambu shell buying expedition down the coast. It is an oddity of Tolai society that tambu-the precontact currency-has not only survived a century of culture contact but is still an essential for many ceremonial and trading purposes. By and large, cash is still regarded as a useful commodity rather than an essential means of exchange.

A few individual Tolai 'big men', mostly farmer-traders, commanding a family group labour force, probably devote as much time per week to economic production as the average Australian farmer; but these men are, as yet, exceptional. The average Niuginian agriculturist is still a long way from clearly appreciating that enhanced living standards involve regularity of performance in economic productioninvolve more work. His motivations are still those of the subsistence farmer, and he is not under economic pressure as industrial civilisation's victims recognise the term. While it can be validly argued that the building up of that pressure is an essential ingredient in any schemes for systematic economic development, the nature of the villager's response still cannot be predicted with any certainty. It is 
obvious that the prevailing quirks (from a European viewpoint) in native economic and social attitudes constitute formidable obstacles to a smooth and rapid transition to completely individual farming.

In the paragraphs above an attempt has been made to outline certain questions concerning the willingness and ability of Niuginian cultivators to change over to a completely individual system of commercial farming. My general conclusion is that, whilst the tenure problem is basically one of endeavouring to direct and accelerate evolutionary trends that arise from the introduction of cash crops, villager attitudes limit the scope of the initial approach that must be made. Broadly, the problem is an educational one, and in my view the best chance of success would have lain in concentrating efforts on the systematic individualising of cash-crop area tenures in the initial stages of economic development. In some areas this would not have been possible; but in no area was it attempted. In the most evolved tribal localities the usual results accruing from population pressure and progressive fragmentation of holdings are now becoming clearly apparent. Rationalising the tenures of 'rural slum' tree-crop areas is now a priority problem.

An approach along these lines leaves the question of subsistence gardening, based on shifting cultivation, to be resolved at a later time. This has obvious risks. The desirability of 'rationalising' both aspects of indigenous agriculture jointly is not arguable; the question of feasibility is another matter.

Mention was made earlier of one problem complicating the individualisation of subsistence gardening tenures: the degree to which garden clearing has been of necessity a communal task and, with this, the degree to which the economic and religious aspects of food production are woven into the social fabric. There remains, however, another aspect, which I approach with some diffidence. Even assuming that wholehearted indigenous support was forthcoming for a complete changeover to individual holdings, can we supply feasible answers to the technical problems involved in preventing erosion and maintaining soil fertility, once bush fallowing has been replaced by more advanced agricultural methods?

The answers evolved in temperate regions, for more advanced economies-techniques based on mechanical equipment, contour ridg- 
ing, crop rotation, the use of fertilisers and of livestock-appear to me to have scope for only a limited application in the New Guinea village agricultural context.

The estimated proportion of village cultivation in the Territory carried out on critical slopes is not known to me, but it must be relatively high. In many areas one can walk for days without seeing a garden on a slope of less than 20 degrees, and cultivation on slopes of 40 degrees is not uncommon. (In parts of the Chimbu district the angles verge on the fantastic.) Most of the country generally is so broken that the proportion of truly arable land, in terms of noncritical slopes, is probably much lower than is commonly believed.

In a majority of tribal areas the terrain will impose strict limits on the extent to which a subdivision of the land into individual farms, each suitable for subsistence food growing and commercial cropping, can be laid out. Many of the slopes that currently support subsistence gardening would not be suitable for economic crops, particularly the tree-crops which, on current probabilities, will continue to be the mainstay of the agricultural economy. (Coconut palms, economically cultivable at up to 1500 feet altitude, and tolerant of steep slopes, may be an exception.) If the Coalition Government adheres to the old Agriculture Department plan that cash-crops should be systematically promoted, in areas selected by technical offcers, these will naturally tend to be concentrated where the terrain is favourable, leaving the smaller pockets and more difficult areas for food growing. A pattern of this sort dovetails well enough with the concept of tree-crop plantation layouts, each incorporating a number of individual holdings; but it does not lend itself to a layout of completely individual farms, each growing both subsistence food and economic crops.

Despite the pressures of soil conservationists, it is probable that the cultivation of steep slopes will continue, as a matter of sheer necessity, with a tendency for even steeper ridges to be brought under gardens as area populations build up. To date, the practice has not resulted in any marked degree of erosion, this, paradoxically, because of the technical crudity of the agricultural methods employed. Under existing techniques the land is rarely cleared completely. Large trees are ringbarked and left standing, or felled, without stump eradication, to produce a terracing effect. The digging stick is still the main agricultural 
implement, and the soil is not tilled. Crops are commonly planted in mixed stands; at no time is the garden area completely devoid of cover. These practices, coupled with fallow periods of up to seven years, during which the area reverts to heavy secondary bush, prevent erosion and apparently maintain fertility.

Such methods are obviously wasteful of land. As yet, apart from causing virgin forest to recede, they do not seem to have produced many cumulative harmful effects. (Some erosion is discernible in parts of the Markham Valley and the Eastern Highlands.) A marked increase in population, which on current trends may be confidently anticipated in many areas over the next twenty-five years, could, however, by accelerating the bush fallowing cycle, drastically alter the existing picture. It must therefore be concluded that a time factor, less pressing than that existing in regard to permanent tree-crop cultivation, also operates in regard to changing subsistence gardening methods. The difficulty lies in selecting and promoting feasible techniques.

A system of complete individual farming necessarily implies a cessation of shifting subsistence agriculture, for otherwise the holdings would need to be larger than the amount of arable land-in most areas-can support. Fixed cultivation of annuals in turn implies promoting at least the rotation of crops, and use of the hoe and of insecticides. Clean clearing, contour ridging, composting and allied farming techniques not traditionally practised by Niuginian farmers are also implied in the changeover. All of this entails additional work and expense to the cultivator, without necessarily increasing his income. The disposal of perishable food crops, surplus to local domestic requirements, would constitute, in many areas, major transport and marketing problems.

Again, while emphasising that I have no pretensions to agricultural knowledge, my reading of current literature has left me with a strong impression that much work remains to be done on the application of modern agricultural techniques to tropical soils, and under tropical climatic conditions. In Africa, the introduction of the hoe and the plough have promoted erosion; the desire and economic ability of the average Niuginian cultivator to use artificial fertilisers remain at best doubtful factors. The Niuginian is as yet a tyro in regard to animal husbandry; he is even further removed from an appreciation of the 
economic use of livestock in agriculture. In the days of the Belgian Administration, the Congo probably led the then colonial world in research into wet lowlands agriculture. $\mathrm{My}$ recollection of reports on some extensive Belgian work on systems of strip cultivation without artificial fertilisers is that quite lengthy fallow periods were still required.

The general conclusion I have reached regarding the modernisation of Niuginian subsistence agriculture is that the approach needs to be empirical, and exceedingly cautious. There are too many incidental problems to which there are not yet conclusive answers. Admittedly, changes must be effected, and there is a time factor operating. But the need for change has not the same urgency that exists in regard to the 'rationalising' of tree-crop areas.

The progress achieved in tenure conversion in Niugini since 1945 is relatively insignificant. The 1958 District Commissioners' Conference concerned itself mainly with discussion of land tenure problems. In the light of Niugini's later interest in Kenya land tenure reform it is interesting that the notes distributed to facilitate this conference's discussions included several extracts from a Despatch No. 44 of 1946, entitled 'General Aspects of the Agrarian Situation in Kenya', and written by the then Governor of Kenya, Sir Phillip Mitchell, to the Secretary of State for the Colonies. This 1958 Conference passed five resolutions generally aimed at promoting the individualisation of customary tenure in Papua New Guinea. They included recommendations covering the compulsory acquisition (where necessary) and redistribution to indigenes, on a leasehold basis, of unused 'tribal' land, and making optimum use of local authorities as intermediate landlords for the promotion of local area economic development. There does not seem to have been any attempt to implement the District Commissioners' recommendations.

In 1960 the Australian Minister for Territories announced a policy designed to encourage the development of individual land ownership and leading towards the eventual abolition of customary forms of tenure. But by 1970 only some 270 small blocks had been converted to freehold. In 1971, four new land bills based on Kenya land legislation were introduced into the House of Assembly. They provoked wide public controversy, during which representatives of several of the 
major religious missions combined with conservative indigenous politicians to voice conventional traditionalist fears. As the successful passage of the bills through the House of Assembly seemed dubious, the Administration decided to withdraw them pending further explanation of their expected policy effects. The National Coalition Government thus far has shown no public signs of being interested in reviving the draft legislation dealing with the adjudication and registration of tribal lands. In the meantime, with Niuginian population and expectations both steadily rising, the backlog of undecided land disputes continues to retard development and promote armed conflict, particularly in the congested Highlands Districts. 


\section{The Kenyan model}

\section{T. Bredmeyer}

Land tenure conversion was introduced in Papua New Guinea in 1964 with the aim of translating customary rights into English law, because it was considered that customary tenure gave inadequate security to a person wanting to plant cash crops. This policy was taken from Kenya, but the procedures adopted for carrying it out differed markedly from those in Kenya. A little earlier, Papua New Guinea had already introduced legislation for the ascertainment of customary land rights as an end in itself, that is, without tenure conversion, although it was hoped that some land owners would then want to go further and convert their tenure. This policy had no counterpart in Kenya, where customary rights are ascertained only during the process of tenure conversion, but in this case the relevant Kenyan procedures were copied.

Both policies, the ascertainment and the conversion of customary land rights, have been in operation in Papua New Guinea for nearly ten years. It is therefore opportune to ask how successful they have been. Was the Kenyan policy of tenure conversion appropriate to Papua New Guinea? Were the procedures adopted in Papua New Guinea effective for carrying out that policy? If not, would the Kenyan procedures have been better? Even if the Kenyan policy of tenure conversion is not appropriate, are the Kenyan procedures for ascertaining the ownership of customary plots effective and can they be applied without tenure conversion?

The policy of tenure conversion has never been vigorously implemen. ted in Papua New Guinea, despite the belief expressed in the preamble to the Land (Tenure Conversion) Ordinance 1963 that the provision of a method of giving guaranteed individual titles to land was a most efficacious way of promoting the agricultural development of the country and the economic well-being of its agricultural population. Systematic tenure conversion was confined to the Northern District and at the end of 1972 conversion orders had been made in respect of only 595 plots. The process was entrusted to a judicial tribunal, the Land Titles Commission, which was provided with only a small staff 
and a limited budget. Further, conversion was carried out as an exercise in land tenure reform and-in contrast to Kenya-not as part of a many-sided attack on the agricultural problems of the area. The Government even decided against using loans as an incentive; a farmer who had converted the tenure of his land could not expect to get a government loan or, at least, to have a better chance of getting a loan than a farmer unwilling to convert.

In Kenya, on the other hand, Government and people support 'land registration' (as the whole tenure conversion scheme is called) with the fervour of a religion. They claim that it has transformed agriculture: that within a few years mud huts and scattered subsistence patches have been replaced by small farms with good houses and neatly prepared fields. Most farmers keep quality cattle for meat and milk, use their manure as a fertiliser, and rotate grazing with cropping. Farmers have doubled or trebled their incomes, and in some cases the increase has been twentyfold. The Kenyan Government gives a very high priority to 'land registration'. It aims at 'registering' all the arable land in the country and should have 15 million acres 'registered' by 1974. The government department in charge of 'registration' has a staff of 3000 and will spend $\$ 15$ million in the period 1970-4. For detailed information on the Kenyan scheme see Clayton 1964 and 1970; Fleming 1968; Kinyanjui 1971; Lawrance 1966; Sorrenson 1967; Swynnerton 1954; Taylor 1969.

The limited success of tenure conversion in Papua New Guinea compared to its evident success in Kenya might suggest that the process was unsuitable or unnecessary in Papua New Guinea. Yet, in 1969, Rowton Simpson (1971), one of the architects of the Kenyan scheme, examined tenure conversion in Papua New Guinea and reported that the Kenyan system was eminently suitable in selected areas, but that it has never been properly applied. This advice was supported by a party of local land officials who visited Kenya in 1970 and accepted by the government of the day. Legislation was subsequently prepared to apply the Kenyan procedures more closely to Papua New Guinea, but these bills were strongly attacked and therefore withdrawn in 1971. Yet the Commission of Inquiry into Land Matters, which has been established in the meantime, will, in examining the value of 
tenure conversion, of necessity have to consider the relevance of the Kenyan model.

The term 'land registration' is used in Kenya to describe a process which involves the adjudication of all customary rights to land within a declared area, the consolidation of scattered fragments where appropriate, the setting aside of land for new roads, schools, village areas and the like, and the registration of titles. Upon registration, a local Land Control Board (with a majority of local land owners) and a local Registry are established, and all major dealings in registered land must be approved by the Land Control Board and registered to be legally valid. The conversion procedure differs depending on whether or not consolidation of scattered fragments is required. Since 1968 the procedures are contained in separate statutes, the Land Adjudication Act and the Land Consolidation Act.

The adjudication process can be summarised as follows. The Minister for Lands and Settlement declares an adjudication area when this has been requested by the county council and after satisfying himself that the majority of land owners supports this request. A team of officials is then formed and the area broken up into adjudication sections of about 6000 acres each. Public meetings are held to explain the process. A committee of not less than ten land owners is appointed for each adjudication section and provided with an official as its clerk. The boundaries of all plots within a section are then cut and marked by stakes by the land owners and a demarcation officer, and rights of ownership as well as all subsidiary rights are recorded by a recording officer. Disputes are decided by the Adjudication Committee. Appeals are heard by an arbitration board which also consists of land owners. In addition to hearing disputes, the Adjudication Committee must safeguard the interests of absent persons and persons under a disability, such as infants and lunatics. Absent persons can also assert their rights through an authorised representative.

When all plots have been demarcated, all rights recorded, and all disputes and appeals determined, a record of existing rights is prepared, and two months are allowed for any person to challenge the accuracy of that record. Any objections are determined by the adjudication officer who is the official in charge of the adjudication. Then a 
committee of land owners and officials sets aside land needed for new roads, schools and other community purposes which is bought by the county council. Access is provided to all blocks and where a block does not adjoin a road this is often done by marking a laneway along the common boundary of two blocks that do front the road. All land owners are required to erect cattle-proof fences or to plant cattle-proof boundary hedges. The land is then surveyed either by aerial photography (the hedges and fences are essential for this) or by ground methods.

When the adjudication is complete, the record of it is sent to the Land Registrar for registration. He can register an individual or not more than five co-owners or the elected representatives of a group as the absolute owner of the land. Some of the other customary rights recorded can be registered as a lease, charge, easement, restrictive agreement or profit. A lease for less than two years need not be registered but is nevertheless binding on the absolute owner. A licence is binding on the absolute owner who gave it without registration and the Registrar can protect it by a caution which binds the owner's successors in title as well. The Registrar can note on the register that an owner is a trustee. Any customary tights that do not fit into these categories are protected without registration as overriding interests.

The procedure in a consolidation area is a little more complicated. As with an adjudication scheme, all the plots are first demarcated, all existing rights recorded and disputes determined by a committee. All the plots are measured and the areas calculated; thus a farmer may have ten plots totalling three acres scattered over an area of two miles' radius. As with the other scheme, a record of existing rights is prepared and two months are allowed for objections to be made to the adjudication officer. Land is then set aside for roads and community purposes. This area is measured and converted into a percentage of the total area of the consolidation section and every owner suffers the like 'percentage cut' from his area. If, for instance, 200 acres or 3.3 per cent of a consolidation section of 6000 acres are set aside for community purposes, each land owner will suffer a 3.3 per cent cut in his acreage. That is to say, land required for community purposes is not purchased as in an adjudication scheme but the loss is spread evenly among all owners. 
When the community land has been set aside, a consolidation committee of land owners and officials (the land owners in the majority) marks out the new consolidated farms. The aim is to give each farmer land of equivalent area and value to his former scattered plots and sited to include, if possible, his most valuable or important fragment. If an owner gains improvements by this process, he must compensate the former owner for them. This may be done in cash or, if the improvements are coffee trees, by the owner planting an equivalent number of coffee trees on the former owner's new farm and allowing him to harvest the present trees until the new ones are bearing. It is also quite common for fully grown coffee trees to be transplanted without any apparent ill effect.

In a consolidation scheme, land is set aside for village gardens where all those whose land is not large enough to support them fully as farmers get their plot. The small land owners gain by this for they are closer to the village amenities and possible alternative or supplementary employment. People who are found to have no land at all may also get a small plot in the village. These people are normally acceptees from a foreign tribe who farm under permissive occupancy from land owners in return for a small tribute. Frequently on consolidation their permission to farm is withdrawn because consolidation allows a land owner to use all his land effectively, instead of lending some of his more remote and least desirable fragments to acceptees. Some committees have given these acceptees a small plot in the village area and deducted it from the area of their host land owner, but other committees have not recognised their needs and the acceptees either have to purchase or lease land from the owners or become landless. Some farmers choose to take their land in two plots, a quarteracre house plot in the village and the balance as a farming block, and build a house on each block.

When consolidation is completed, two months are allowed for appeals after which no further appeals can be entertained. The land owners are required to enclose their properties by hedges or fences, and the papers are sent to the Registrar for registration.

In considering the benefits of 'land registration' it is convenient to separate the various stages in the process. The first stage, the adjudication of existing rights, was greatly valued by the African land owners 
because it ended litigation which hitherto was endemic. The Kikuyu in 1952, for example, spent $\$ 220,000$ on court fees for land cases, let alone the money spent on bribing witnesses and the many man-hours lost that could have been devoted to more productive agriculture. The Kikuyu had been dealing in customary land for several decades before land registration began in the mid-1950s, and as land became short people challenged transactions entered into by their fathers. There was much litigation over former sales, for instance over whether they were outright or redeemable-which meant that the vendor or his heir could repossess the land at any time by tendering the original purchase price to the purchaser. Clearly, redeemable sales hindered economic developmrent, for the more a purchaser developed his land the more likely it was that it would be taken back from him. There was also much litigation over the status of acceptees, such as whether a man was an acceptee who could be easily dispossessed, or the recipient of a legally valid gift of the land who could not be dispossessed. Population growth produced a land shortage which in turn prompted land owners to evict acceptees who had been allowed to farm often twenty or thirty years before, when land was plentiful.

The systematic adjudication of all competing claims at the one time was appreciated by the land owners. Further, the fact that a man had to support his claim before a committee of his peers discouraged frivolous and spurious claims that would have been made if an outside judge had determined them. The process allowed compromises to be reached; an owner would concede a little on one boundary if he gained a little on another. Adjudication by committees was also much quicker than if an outside judge had been used, for he would have taken much longer to learn the customs of the area and to assess the reliability of the many claimants and witnesses.

The land owners accepted adjudication as final even in areas where some of the owners were away in detention camps when the process was carried out and the protection of their interests had been entrusted to the committees. It would have been easy for a pro-government committee to have ignored the rights of an absent Mau Mau detainee, or for the detainee on his return to allege that his rights had been ignored, but in fact this did not happen. The Mau Mau extremists and leading national politicians alike enthusiastically supported 'land 
registration' sponsored by the colonial government before Independence in 1963 and expanded it after Independence. In law and in practice adjudication ended litigation and the only disputes that now occur in registered areas are over boundaries which are claimed to have been subsequently and illegally altered.

The Kenyan Government claims that adjudication, in ending litigation and establishing visible boundaries, produced better agriculture because the owners saved resources formerly devoted to litigation and gained physical and psychological security of tenure. This claim is justified for, as already noted, redeemable sales hindered development, but it is a difficult claim to quantify. Certainly, money formerly spent on land litigation was saved, but this may not have been invested in better farming and, more importantly, adjudication was merely one part of a series of improvements introduced at the same time, including new crops, better marketing facilities, the establishment of a dairy industry, cattle dips and artificial insemination, land-use planning according to slope and fertility, and excellent farmer education.

On the other hand, the benefits of consolidation, especially in the Kikuyu area, are obvious. The average farmer had previously ten fragments and this hindered good farming. Consolidation saved much unproductive time, spent walking between fragments. It also enabled a farmer to enclose his land, to buy good cattle without fear of disease or intrusion on his pasture from his neighbour's poorer cattle, and, by penning the cattle at night, allowed him to collect the manure and use it to fertilise his crops. Hitherto it had only been feasible to keep cattle on the homestead plot and difficult to transport the manure to other fragments. Further, after consolidation agricultural officers could plan the layout of farms with the owners. Thus in areas where farms ran from ridge top to valley bottom, the steeper slopes were reserved for grazing, the better drained slopes for coffee and tea, and food crops were planted on the heavy soil at the valley bottom. Consolidation also reduced inspection time, so that agricultural officers could assist a larger number of farmers.

Consolidation was applied in some areas without the full support of the farmers and had to be abandoned due to their opposition. The process causes great social disruption and requires the land owners to work hard cutting boundaries, serving on committees, planting hedges, 
building new houses (in some cases), and planting new tree crops. It can therefore only be applied to an area if the people strongly support it, and is only justified if a prior study has shown that the existing fragmentation is agriculturally wasteful.

Adjudication as well as consolidation produced two additional general benefits. The first was that all the work required of the land owners kindled their interest in better land use, and where agricultural advice and assistance were available, this interest was directed to new crops, stock, or fences. Most farmers had some capital to invest at the time of adjudication or consolidation, though of ten in the form of labour rather than cash, and with good agricultural advice and due to the availability of quality seeds and livestock, they were able to invest wisely. In the few areas where this help could not be given, the agricultural results were correspondingly poorer.

Secondly, either scheme involved the land owners together with councillors and government officials in setting aside land for community needs. The setting aside of areas for markets, shops and houses has been particularly successful. As the population grew and the farming diversified, a substantial local trade in vegetables developed between the different agricultural zones.

Instead of the few poorly stocked village stores, run by land owners on a part-time basis, there are now a large number of specialised shops, run by butchers, shoemakers and the like, which have greatly improved the quality of rural life. Village areas for which ten or fifteen years ago only an ambitious plan existed, are now small but flourishing urban centres.

What were the benefits of the registration of interests in land which followed adjudication and consolidation? First, it was a method of recording the adjudication or consolidation so that it could not be legally challenged. This reason alone, however, is not sufficient justification for registration, for the law could have made adjudication and consolidation final without registration, in the same way in which the judgment of a court is final. Second, registration made all future dealings in the land easy, public, and legally safe. The registry provides simple forms for all the common transactions such as transfer, sale, lease, mortgage and the granting of a profit, and the land owners can complete these forms at the registry without the aid of lawyers. 
But again even if dealings are not registered, it is possible to ascertain changes of ownership by periodic re-adjudications, every ten years or so. This would be a comparatively minor operation, since not very many blocks would have changed hands since the previous adjudication and only a few of these changes would be disputed. Still, it is undoubtedly cheaper to register dealings as and when they occur. Registration, finally, allowed dealings to be controlled by the Land Control Boards.

All major dealings in registered land are subject to approval by a local Land Control Board which is required to refuse approval if the transaction is markedly unfair to one of the parties, or if the transferee already has sufficient agricultural land or is unlikely to farm it well. Where the transaction is a subdivision, the Board is required to refuse approval if the subdivision is likely to reduce the productivity of the land. Transactions to non-citizens are prohibited. In addition to these official criteria the Board is free to use its discretion as it likes and its decisions are immune from judicial review although subject to appeal to a provincial Control Board and ultimately to a central Appeals Board composed of government ministers. The majority of local land owners on the Board ensures that general interests are fully considered. It is, for instance, common for a Board to refuse a transfer to a stranger who is unacceptable to the local community. The 'freedom' of a registered owner to deal with his land is thus subject to similar community scrutiny as were dealings in customary land.

Very few Kenyan farmers have so far lost their land through foolish sales or mortgages, but cultural factors have probably been more important than the Boards in securing this result. Kenyans value their land enormously as economic and social security and are reluctant to part with it. Although many registered owners are absent, away working in the towns, their land is not sold or leased but is farmed by their wives and relatives.

The major problem of land control and registration is the high number of subdivisions, especially those between the heirs of a registered owner, which are not submitted for approval because the applicants fear that the Board will refuse approval on the ground that the productivity of the land will be reduced. This criterion is an attempt to keep holdings at an 'economic size', defined as the size 
necessary to give an average farming family subsistence plus a certain cash income from crops currently planted in that area using the farming methods commonly employed. The concept is fraught with difficulty, for family size can vary, aspirations can differ, market prices can fluctuate, and crops and farming methods can change quickly. But unregistered dealings are legally not as dangerous as they might appear, because the Registered Land Act requires a prudent purchaser to inspect the land in any event because licences, short-term leases, and overriding interests are valid without registration.

The Government and the people in Kenya believe that they owe much of their economic progress to their 'registration' scheme. How relevant is their experience for the future of Papua New Guinea? It would appear that this depends first of all on how similar the economic and social development aims of this country are to those which Kenya has adopted. But this is not entirely true. The Kenyan 'registration' scheme is flexible enough to be of assistance in implementing a wide range of policies. Further, even if the scheme as a whole should prove unsuitable for Papua New Guinea, some of its features or some of the experiences made during its operation could be of considerable help in devising a different scheme for this countrty. It may be more useful, however, to compare the Kenyan scheme briefly with the present needs and problems in this country than to speculate about the future.

Despite the many difficulties caused by past alienation of land to Europeans, the frequent disputes over customary land clearly form the most serious land problem. As far as disputes between large (tribal) groups are concerned, the Kenyan experience is probably of little help. These disputes will almost certainly have to be resolved by an outside authority, since it is unlikely that the disputing parties would agree on the composition of an adjudication committee which could work out a solution both sides would accept. Most other land disputes could be resolved by a committee of land owners. And it would be much cheaper and more effective to determine the ownership of all plots in a certain area at the same time than to deal with plots only when a dispute arises. Systematic adjudication by a committee of land owners, apart from all other possible advantages, is a better way of dealing with the present flood of active and latent minor land disputes 
than the ad boc determination of individual disputes by an outside judicial body.

Besides, adjudication of existing rights is already valued for a number of reasons in ateas of extensive cash-cropping like the Gazelle Peninsula and parts of the New Ireland and Madang Districts. This is shown by the fact that two million acres of customary land have been demarcated in these areas by demarcation committees since 1965 . Unfortunately, the adjudication process, so well begun, has not been completed. Due to shortage of staff and funds the Land Titles Commission only determined ownership and made surveys of some few thousand acres. Nevertheless, the initial progress shows that adjudication is needed and valued by the land owners, who are willing to do the work involved-and the Kenyan adjudication procedures would certainly be more effective than the existing ones.

In these areas adjudication should be followed by the compulsory registration of all subsequent dealings in adjudicated land if dealings are likely to be numerous, otherwise the adjudication record could be brought up to date by periodic re-adjudications. Generally speaking, in the three areas mentioned the very factors that make adjudication desired-the extensive cash-cropping, dense population, and reasonably good land use-also mean that dealings are numerous and likely to be disputed and hence registries should be established.

The prime aim of registered dealings is to make them safe from legal challenge. In the case of urban land they could produce enormous economic benefits as well. Much of the customary land around the major towns such as Port Moresby and Lae is at present unused. Its customary owners do not have the capital to develop it, are unable to borrow money on the security of customary land, and there are few sales or leases at customary law which would produce its development. The owners could sell or lease the land to the Government, but are reluctant to do so because they regard the returns as inadequate. However, even if the law preventing them from selling, leasing, or mortgaging the land to expatriates were changed, it is extremely unlikely that expatriates or anyone else would invest on the security of unregistered land when land litigation and trespass on land are so common. Adjudication and registration would allow the land owners 
to subdivide, plan the use of the land with the assistance of the town planner, lease or sell some of the blocks and retain others for their own use, and businesses could be financed out of the rents or purchase moneys received or from money borrowed on mortgage.

Adjudication and registration would also be valuable in the New Guinea Highlands. Adjudication would reveal that people have planted coffee trees on land to which they hold only usufructuary rights. On registration the conflict between the land owner, usually a clan, and the planter, usually an individual, could be resolved by registering the planter as owner of the land and trees subject to a payment of compensation to the clan, or by registering the clan as owner of the land and trees subject to a payment of compensation to the planter, or by registering the clan as owner subject to a lease to the planter.

Also in the Highlands most individual coffee farmers own scattered groves of coffee trees which are uneconomic and require consolidation. Bearing in mind the Kenyan experience, consolidation should only be introduced where the people fully understand and support the process. Further, consolidation is more likely to be supported by the people and the agricultural benefits will be much greater if it is part of a comprehensive agricultural plan for the area. According to noted agriculturalist Rene Dumont (1973), such a plan should include soil conservation measures, the introduction of ley farming (cropping followed by grazing on improved pasture), much higher coffee yields per tree, and improved farmer education-a plan remarkably similar to the Swynnerton Plan implemented in Kenya in the 1950s (Swynnerton 1954). Any study of Kenya's land registration system should also include a study of its concomitant agricultural policies.

Finally, dealings in adjudicated or registered land should be subject to control to prevent exploitation of the unsophisticated. At present (early 1973) the Minister for External Territories must approve all transfers of tenure-converted land and the Cabinet must approve all leases and mortgages. This control is adequate but far too cumbersome. The Kenyan system of control goes to the opposite extreme: power is vested in local land owners rather than at the very head of government. The Kenyan system may not be a good model to copy, for it may give too much power to local land owners and too little power to central or local government. 
Kenya has had a long, extensive, and fairly successful experience of the various processes involved in land adjudication, consolidation, and registration, as well as in the control of subsequent dealings. Papua New Guinea's Government would be wise to study that experience carefully before revising or replacing its present policies and procedures. 


\section{The Niue alternative}

\section{R. G. Crocombe}

Rights to most lands in the Pacific were traditionally held by groups. But no single group held all rights to a particular area of land. Various levels of groupings were associated with each plot. One can think of groups of people radiating out from a piece of land and having different and more or less intensive connections with it. Rights and obligations varied at each level, but the largest units tended to have rights relating to the defence of a given territory and to those areas within it which were not intensively used; medium-scale units were usually associated with larger areas of highly productive land, whereas the smallest units (including individuals) held rights to particular gardens, trees, and the like.

The nature and the extent of these rights depended not only on certain general customary principles but also on the ever-changing social and political realities in each individual case. Colonial governments understandably tried to reduce this complexity and flexibility in the hope of encouraging a more productive use of the land. They usually aimed at reducing the number of levels at which rights could be held, at a more precise definition of the types of rights that were to be recognised, and at making these rights independent of changing circumstances by recording them in a register. They frequently succeeded, but often by throwing out the baby with the bathwater. At the end of the colonial era the introduced laws generally recognised too few levels of rightholding and did not provide enough ways of adjusting the rules to the realities of people's lives. The goal of higher agricultural production, however, was almost never achieved.

This was also the case in Niue, a small, now self-governing territory of about a hundred square miles, inhabited by less than 5000 people, lying between Tonga, Samoa, and the Cook Islands. The land law introduced by New Zealand in 1902 provided (below the level of government itself) for only one level of rights - that of the individual. By prohibiting the selling, giving, willing, or even abandoning of land rights, it replaced a possibly excessive flexibility with a certainly 
excessive rigidity; under the colonial law rights to land could be acquired only by accidents of birth - that is by compulsory inheritance. Fortunately for Niue this law remained largely theoretical. In French Polynesia and the Cook Islands, where similar legislation was put into effect, it had most serious and rather unexpected results. The price for the simplification of the traditional land tenure system was a quite fantastic fragmentation of the few recognised rights at the one accepted level. In some cases the rights to a single house-site are now shared by hundreds of individuals.

Most colonial governments in the Pacific tried to individualise land rights and disregarded rights held by groups as such, but some, especially Great Britain in Fiji, chose a different approach; they focused on one level of groupings and neglected the rights of larger or smaller groups as well as those of individuals. The new land laws introduced in Niue in 1969 are based on a policy which tries to steer a middle course. They provide for both individual and group interests in the same land, but they use, at the insistence of the people of Niue and their elected representatives, the traditional descent group as the basic land holding unit. (For details see Crocombe 1971a, and McEwen 1968.) For this reason they form an interesting alternative to the 1971 land bills in Papua New Guinea which were modelled on the essentially individualistic Kenyan legislation.

The main unit of land holding in Niue is the mangafaod. As with any descent group, this term has no precise meaning. Rather, it has a range of related meanings which vary with the context. The same applies to the English term 'family', which also refers to a form of descent group, though such terms can never be translated exactly into other languages, because the shades of meaning alter with the cuiture in which the term is used. Nevertheless it is possible to distinguish certain common features of customary descent group tenures which are widespread in the Pacific in various forms.

First, the membership of any descent group is and must be continually changing. New members come in by birth, adoption, and in some situations also by other processes. Other members go out by death and (in varying degrees and circumstances) by emigration, marriage, adoption, banishment, and the like. Second, the rights of group members are not equal. This important fact is often misunder- 
stood. The rights, powers, benefits, and obligations of each member change with age, seniority, sex, personal capacities, number of offspring, place of residence, relationship to other groups, physical need for land, and various other factors. Third, each person has rights in a number of descent groups. His strongest links are usually with the group of his father, the next strongest with that of his mother's father, the next strongest with that of his father's mother, and so on. But the comparative strength of these links is modified by other principles. In traditional practice, then, there is no exact number of members of a group; rather each group consists of an ever-changing range of persons with altering actual or potential rights.

This practice must be drastically changed if rights of groups to land are registered as under the new legislation in Niue. Any registration of group rights involves (as the result of decisions which must be partly arbitrary) the exclusion of distant members, the confirmation of the rights of a core of members, and the replacing of the unique and flexible rights of individual members by a uniform and stable (or at least more uniform and stable) set of rights.

It is important to note that Niue's descent groups are defined only in terms of land, not vice versa. Hence the registration procedures start with the court announcing that it will determine which group has title to a certain named and surveyed piece of land. It does not attempts to determine who the members of a certain mangafaoa are or what lands they are entitled to. This is the only sensible way, for there is no such thing as a mangafaoa in the abstract. The law requires each mangafaoa to have a name, but the court has often to adjourn and request claimants to give a name to their mangafaod-sometimes it even has to choose a name for them. In either case this name is usually that of a 'source' ancestor.

In theory the term mangafaod refers to an endless network of relatives tracing from a common ancestor, but as soon as it is applied in practice this endless network is found to be limited by a range of other criteria, which are different for each situation. In other words, the general idea of mangafaoa is based on blood relationship-a biological reality - but the mangafaoa as a social reality is shaped by a set of selective principles within this biological framework. 
Descent group ideology traces descent from a single ancestor. The biological reality, on the other hand, is that everyone is descended not from one but a large number of ancestors-two parents, four grandparents, and 256 direct ancestors only eight generations ago. This is about the time of Captain Cook's arrival in Niue, but it was probably settled at least a thousand years before that. In fact almost nobody in Niue traces his claim to land from even one mangafaoa existing eight generations ago or claims membership of more than a few of those existing today. If it were otherwise the whole system would long have collapsed. No group land tenure can work if each individual is effectively the member of hundreds of descent groups. Descent group ideology, supported by the shortness of human memory, tries to reconcile biological reality with social necessity. The mangafaoa are named after an ancestor, but only one out of many. Moreover, this 'source' ancestor is not the same for all time. It is a moving source, changing every generation or two. The people remember that person who happens to be the common ancestor of the core of living members of a mangafaod at any particular time.

The Niue legislation has adopted this ideological approach. It requires the court to determine 'ownership' primarily by 'ascertaining and declaring the mangafaoa by reference to the common ancestor thereof'-thus clearly implying that there is only one common ancestor (who counts). To ensure that the system will work in the future, the court has to go further than that. It is not enough to accept the selectivity implied in the descent group ideology for the past; a similar process of selection must continue. For instance, in the traditional context the concept of the 'source' ancestor did not mean that his descendants had automatically effective rights to the land associated with him. A connection with the 'source' ancestor was only one of several criteria. For this reason the law requires the court to collect information on who was buried on the land, who used it or had other connections with it. But some of these other criteria are in the process of becoming obsolete or being lost. If adequate substitute provisions are made this is no problem, but as yet this does not seem to have happened.

Further, the 'source' ancestor has to be kept moving so that more 
distant branches of the descent group continually phase out. In some cases the court has acknowledged this and awarded land to claimants who named themselves or their fathers as the 'source', although they were well aware of earlier 'sources'. But the land records can change this process because they remember details which would be customarily long forgotten. This can have very serious effects. If the 'source' is not kept moving or alternative selective criteria are applied, the system will become hopelessly congested because hundreds of 'owners' will have tiny fragmented tights in any one plot of land-and it will worsen instead of improving the lot of the people.

So far this has not happened in Niue, but there is clearly the danger that it may. Whether this danger will become real depends mainly on how the court interprets 'custom and usage' and how this interpretation will influence the attitude of the people. 'Custom and usage' is a flexible pattern of tendencies, priorities and probabilities, and the records suggest that claimants are being guided by the court's action in previous cases as to how they will present theirs. The following example will illustrate the danger.

It concerns a plot (Anakale, Section 45) of about one acre. An earlier agreed 'source' of this land was 'Tifaulu, who had seven children. Three generations later two of the lines disputed the ownership of part of the land which was to be rented to a European. One party was a man of the blood line and he challenged two women who were adopted children of the former occupying line. The court gave rights to all three and the land was leased as intended. This was in 1939. In the terminology of today's legislation, the mangafaoa consisted of three adults: a man and two women. The rights vested in these three claimants, and they were the effective 'source' of the mangafaoa from then on. (If one had investigated the matter last century, Tifaulu would probably not have been the sole person with rights, but only one of a group which was the then effective mangafaod.) On 17 August 1970 the court reheard this case under the new laws. The disagreement between the two parties of 1939 still existed, but instead of giving it to either or both parties jointly or by partition, the court ruled that the mangafao consisted of all the descendants of Tifaulu - thus legally bringing back in people who by 
customary process had left the effective mangafaoa two to three generations ago.

This is an easy, but in my view bad, solution to a problem of conflict - to go back to a common 'source' a generation or two before it arose and to give joint rights to all the conflicting parties, plus a lot who never even claimed, and tell them to 'live in harmony' and 'resolve their differences' - even worse, tell them to do so 'according to custom'. The court in such cases creates the very kind of problem it was set up to solve. It leaves disputing parties in a state of smouldering conflict. The effect of the court's work in cases like this is to change a system in which people inherited rights selectively from some ancestors to one in which they inherit all rights from all ancestors. If that is allowed to happen on any significant scale, it would have been better never to have established the court. Land courts and registration systems are very expensive in money, time and skills. That expense can only be justified if they contribute at least an equivalent value in improvements over the previous situation. All land courts have been set up to do this, but not many have achieved it. The actual results need frequent evaluation to ensure that the intended results are being obtained. Papua New Guinea needs to be well aware of this coming problem.

One difficulty is that biological facts are so much easier to record than social facts and that recorded facts assume a greater weight than those which are not. Once the 'source' has been determined by the court and registered, there seems to be a tendency to disregard all other traditional selective criteria. This is particularly serious as descent was in traditional practice probably not even the most important of them. Evidence suggests that in Niue after only one or two generations, undisturbed occupation began to outweigh any claim based on descent. It is therefore doubtful whether it remains appropriate to describe a system of registered descent group tenure as 'customary', or whether it is possible to take 'custom and usage' as a basis for deciding disputes under such a system.

The crucial point, which is frequently not clearly understood, is that land registration and land courts change 'custom and usage', even if they were introduced to preserve them. Depending on the aims and 
the context, this may be a good thing, but if the problems are not appreciated the results can be disastrous.

Descent was traditionally a channel for acquiring land rights, whereas many of the other criteria provided means of reducing them and of transferring them directly or indirectly to those most closely connected with the land. If the legal system only strengthens the channels for acquiring rights, but does not provide equally effective channels for redistributing them, problems of multiple ownership will accumulate quickly. If this is combined with growing land consciousness and rapid population increase, the problems will soon get out of hand. Niue has foreseen these problems and taken steps to guard against them. But my impression is that they may not be determined enough to meet the nature of the problem. Papua New Guinea is only just beginning to grapple with it.

To contain or to reduce the number of persons legally recognised as having rights to land is probably the most important but not the only problem facing a system of registered descent group tenure. Another problem is, who should act on behalf of the group?

Traditionally, the leader of a mangafaoa was known as the pule mangafaoa. But as the term pule implied greater control and authority than Niueans wanted in the new legislation, they chose the term leveki or trustee instead. The court appoints a trustee for the mangafaod of each piece of land. He is supposed to be chosen by the majority of members, whether residents or not. In practice, however, this usually means only adult members, and generally only resident members, and if there is no application, or if only a few express an opinion, the court can, and does, appoint a trustee. A person who is not a member of the descent may be appointed its trustee, but he does not acquire any rights to the land except as trustee. The husband of a woman member, or a senior respected blood relative, or in some cases the Registrar, is appointed.

The trustee's powers are to control the occupation and use of the land in accordance with Niuean custom and to 'alienate' it, but in exercising either power he must 'as far as practicable', consult with members of the mangafaoa. If land is leased, the rent is paid to the court and by the court to the trustee-it is his job to share it as he 
thinks best with other members of the mangafaoa. The trustee may be removed by the court if it is shown that he has not carried out his duties or cannot do so with 'equity' or 'in accordance with custom'. No dispute about this has yet to come to court, but it is an open question how equity or custom will be defined, or even whether they may not conflict in some aspects.

The ways of selecting a trustee and of defining his powers are important issues for Papua New Guinea to consider. It is not just a case of deciding how much power to give him; the more important question is how much power (and money) can he take, whether the Government or his followers want him to or not. Where only gardening land for members of the descent group is concerned, this is usually not difficult, but when it comes to leasing or selling to outsiders, big problems can arise. The main duty of a leader is to guard the interests of his people, but history is full of examples (in the Pacific islands as elsewhere) where they have looked more after their own personal interests - and these are often contrary to the interests of their people.

This is a difficult problem. The Government can instead deal with each member of the descent group direct (as for example in Fiji, the Cook Islands, Guam or Tahiti), but that is unbelievably expensive of money, time and staff-and it is sometimes very inefficient. It also implies that the government officials will look after the people's land rights impartially - but that does not always happen either. I see no easy answer. Many governments have tried to find solutions, but all have their drawbacks. Perhaps the main principle which seems to emerge is that the less the value of the land and the fewer the external dealings the more responsibility should be given to a group representative, and the greater the volume and value of dealings, the more governments should supervise or control. But this is not necessarily what has been done in practice, nor has it necessarily been successful where it has been done.

Protecting the user is a problem everywhere, for one of the problems often unintentionally caused when group rights are registered is that the rights of each person ate made the same, or at least closer to the same than they were traditionally. Customary systems gave some protection to that member of the group who was actually using the land. Registered tenures in the Pacific have usually failed, in practice, to 
provide equivalent protection. Niue aims to overcome this problem by giving occupation rights to individuals within the mangafaoa. Such a right is normally granted to an individual for his personal use for his lifetime ( $o r$ in some cases for a stated number of years). No rent or other payment is made because the person it is granted to is almost always a member of the owning group.

Occupation rights can be cancelled if the rightholder does not make adequate use of the land for a year or more. A difficult problem here is to define 'adequacy' of use or the period of non-use, especially in an agricultural system where land normally lies fallow for some years between plantings. This is not much of a problem for Niue which has plenty of land, but evaluative limitations of this kind can cause tremendous administrative difficulties, and do so in many parts of the Pacific. Papua New Guinea has already had a lot of difficulty applying rules of this kind to land leased from the Government. Occupation rights may also be cancelled if the holder is absent from Niue for more than a year (except for education or other training). This may be easy to administer in Niue where one can leave only by air and only once a week. But for Papua New Guinea, where people can leave their home area by walking, driving, or frequent shipping and air services, the problem of the rights of absentees is very important.

Other forms of transfer of land rights are necessary too. In Niue land cannot be sold (even to Niueans) except to the Government for public purposes. Land can be leased, divided between co-owners, exchanged, reserved for public purposes, or vested in church communities. These transfers must be made through the court, except for minor rights (including leases) which are granted for less than two years. The court must be satisfied that the rent or other payment for the transfer is adequate, and may require the trustee to prove that the majority of members of the mangafaoa have agreed in writing to any proposed alienation. There are not yet enough cases to reveal any principles adopted by the court in determining 'adequacy'. This is unlikely to be a problem in Niue, but the absence of more detailed criteria of adequacy has led to abuse in many countries with similar provisions.

Leases are usually for a maximum of sixty years. Leases for public and church purposes are an exception and may include a perpetual 
right of renewal, provided the land continues to be used for those purposes. (A provision of this kind would help overcome a significant current problem in Papua New Guinea.) If it does not, the lease is cancelled. Another exception applies to land used for forestry, or for commercial and industrial buildings. Longer leases for these purposes are subject to special conditions about their use and the maintenance of assets.

Partitions may be approved by the court if a mangafao becomes too big or torn by internal dispute, but it is required to avoid subdivision into plots too small for convenient use by individuals. Partitioning and combining land (which is also provided for) are necessary provisions to meet changing numbers in the group or major changes in land use. If experience elsewhere is any guide, these provisions will probably not be used much. Exchange of land is also provided for, though it is not expected to be used in many instances.

Reserves may be created by the court if the majority of the mangafaoa want them, for common use by a church or other institution, or for all residents of a village, or for community purposes. If the reserve is no longer used for the intended purposes, or if the agreed period ends, land reverts to the owning mangafaoa. This provision is very simple to operate and could well be considered in Papua New Guinea where unnecessarily cumbersome, protracted, and often acrimonious procedures (including alienation to the Government) are necessary for people to set aside land with legal security for schools, churches, and other community facilities.

Land being used as security for credit leaves it open to alienation if the debt is not paid. The ultimate title to land in Nive cannot be mortgaged or used as security for credit, but rents or other income from land may be in approved cases (for instance, for loans from the Niue Development Board).

Very little land on Niue belongs to the Government, yet there is increasing resistance to sale of land to the Government for public purposes, even though Niue is self-governing. It is interesting to note that under the new legislation, even government land must show the name of the mangafaoa from which it was bought. This suggests a residual tight of the mangafaod if the Government later finds that it no longer needs the land. 
Survey is required for all registration of mangafaoa boundaries, and for occupation rights except those for a house site (one-eighth of an acre) in a village, or up to two acres of farming land. Even for this small population and a total area of 100 square miles, most of which is flat, survey is going to be a task of many years. So far only about one-fifth of the mangafaoa lands on Niue have been surveyed.

For a small, isolated territory borrowing short-term surveyors from outside, survey costs, including all overheads are inevitably high. ${ }^{\mathbf{1}}$ It is difficult to estimate registration and administration costs, but being small, the Niue case is certainly expensive per unit of land handled. The records have cost a great deal of time and money to assemble. They include detailed genealogical records, over several generations, of almost every person born on Nine: a more complete record than almost any other territory in the Pacific possesses.

A very rough estimate of the total staff time and overhead costs in Niue and New Zealand of merely preparing the legislation, the manual, forms, etc. for the introduction of the new system suggests that it would have been of the order of $\$ 100,000-a$ lot of money for a population of less than 5000 . This was not a problem for Niue, as New Zealand paid the main costs, but it is an important question for Papua New Guinea (with its larger and much more diverse populations and tenure systems), which will have to pay for such a system increasingly from local taxation.

The complexity of this relatively simple system, even for a very small and uniform society, is shown by the fact that the Niue Land Ordinance 1969 runs to fifty-four sections, and the manual of instructions to 276 foolscap pages. (This includes 186 pages of a multitude of different forms which have been designed to implement the Ordinance.) Again, places with relatively fewer staff or less finance would probably need to reduce this complexity considerably.

All income from rent or sale of land is paid to the Registrar, who may deduct up to 5 per cent for administrative costs, and then distributes the rest to the trustee or other persons entitled. This is much less than the actual costs. In Fiji, the Native Land Trust Board, even

1 A recent report on the survey of Niue (Berrill 1968) does not give details of teal costs. 
with its huge scale of operations, takes 25 per cent of income for administrative costs and finds that even this does not meet its actual expenses.

In Niue, land registration is free. Again, if it can be afforded this is advantageous. But it is doubtful whether Papua New Guinea could manage without fees to cover at least part of the costs. Accurate estimates of the real costs involved are essential (but have seldom been made in fact) before any plans to introduce new systems are decided upon.

All documents are drawn up in English, but a Niuean translation is provided. In Papua New Guinea with its hundreds of different languages the problem is vast, though the use of Pidgin and Motu may be possible. Effective communication is essential, and if it cannot be achieved this may be a valid reason for postponing land registration where the need is not urgent. Forced registration, and registration which was not well understood, has not achieved its goals elsewhere in the Pacific. It is better to reduce the goals or postpone their attainment than to invest in expensive failures.

Land law must be reasonably consistent with political realities or it will not be accepted as law. But it must also be reasonably consistent with social reality or it will not work in the way intended. The land laws of the colonial era were consistent with the overriding political reality that all major decisions lay with the colonial power. But few were consistent with the social realities of the island societies. They were intended to be, but the persons who drafted the laws had little experience to draw on except their own European cultures, and they had an oversimplified view both of the nature of islands tenure systems and of the extent to which they could be changed by law. The political reality of the 1970 s is of self-governing and independent countries which want fuller recognition and implementation of local values and principles. To use the traditional group as the basis of a modern land tenure system may be a promising way of achieving this. But it must be realised that it may involve just as many problems, changes, and expenses as an individualisation of tenure. 


\section{Customising the law}

\section{J. Lynch}

What do I mean by the obviously invented word customising? Put simply, I mean bringing the received Anglo-Australian land law into line with general customary Papua New Guinea attitudes to land. In strictly legal terms one might say that this is no problem. In Papua, customary rights to land were recognised in the famous Erskine proclamation of 1884 and by consistent administrative and legal policy ever since. In the Territory of New Guinea such rights were specifically recognised in Sections 9 and 10 of the Laws Repeal and Adopting Ordinance 1921, the first ordinance made by the Australian Administration of what had been the colony of German New Guinea. Furthermore, the Native Customs (Recognition) Ordinance 1963 recognised land custom as law, and customary rights are determinable and enforceable through the same judicial organisation as are other (legal) rights. But such an analysis ignores the obvious facts of the situation: there is customary land and non-customary land, and the rules governing each are markedly different.

A real difficulty in trying to discuss the customising of land law is the fact that so little is known of the general customary rules, of significance to lawyers, relating to land-or perhaps it might be more accurate to say that a lot is known but it has never been assembled in a form and analysed in a manner that is particularly useful or meaningful to a lawyer. Thus, in the field of the importation of customary concepts into the area already occupied by law it seems that the Roman Law doctrine that ownership of the land automatically carries with it things on and under the land has no part in popular thinking in Papua New Guinea (if, indeed, it has any real part in popular thinking anywhere), and it and other unnecessarily technical rules could quite readily be abolished-if we could be certain where the conflict with customary thinking lay. It appears, for instance, that the rights of the customary owner of land do not in general automatically override the rights of the owner of, say, trees on the land, so that 
the owner of the trees may well have, in certain circumstances, a better claim to the land itself than the owner of the land has to the trees. In other words, a dispute between the owner of the land and the owner of the trees might well be settled either by giving the trees to the owner of the land or by giving the land to the owner of the trees-in either case, of course, with compensatory payments.

In such cases, if we knew the customary situation, it would technically not be difficult to bring the law into line with customary attitudes, but this may well not be the end of the matter. It would be quite possible, for instance, to provide that on the death of the owner of an administration-leasehold property the subject land would devolve in accordance with custom in the same way as would customary landbut this might conflict with government policy in relation to the nonfragmentation of holdings, such as that enshrined in Part III of the Land (Tenure Conversion) Ordinance 1963-1970.

At a much more fundamental level, the basic customary approach to land ownership may well be so very different from the 'European' approach that we might expect different reactions to and results from much the same type of transaction. In the Gove land case Mr Justice Blackburn is reported as saying of Aboriginal attitudes to land that it seems easier, on the evidence, to say that the clan belongs to the land than that the land belongs to the clan' (Federal Law Reports, vol. 17 1970-1: 270-1). Without wishing in any way to suggest that that unpalatable judgment forms part, or should form part, of the law of Papua New Guinea, it seems to me that Mr Justice Blackburn was describing an attitude that prevails here just as much as in Arnhem Land, and one that is totally opposed to the commodity theory of land that now generally prevails in Australia. But there is nothing peculiar to Arnhem Land or to Papua New Guinea in such an attitude to land. I well remember, as a child, my grandfather's attitude being very much the same. His was one of the first white families to cross the Great Dividing Range in New South Wales and I remember his attitude as being that certain paddocks were 'our' paddocks that we had sold. Admittedly, we had no legal rights to them but that did not mean that they were not still 'ours', in some sense. Probably this is an almost universal attitude of people who are farmers first and sellers of commodities second-an attitude that predominantly citified 
and commodity-orientated administrators and experts have forgotten or never knew.

As a legal consequence of this attitude it may well be that Papua New Guineans have a customary concept of ultimate inalienability of land and that many of the recent claims to alienated land in Papua New Guinea are based to a large extent on such a concept. If this is correct we may be on dangerous ground from the point of view of popular acceptability if we continue to base our land law on a commodity attitude. The Papua New Guinea Government and the Australian Government may have to recognise this defect in land acquisitions, at least those at the relatively early stages of culture-contact, and make appropriate adjustments. It may even mean that a permanent transfer of land is still inappropriate and that provision should be made for a recognition of a continuing 'very close relationship' (Mr Justice Blackburn's phrase) between the customary owners and the transferred land.

Certain lands which are particularly closely identified with a certain group should probably be and be deemed always to have been inalienable, or alienable only subject to a continuing right of association in some way with the land. If perpetual alienability is required for some purpose (whether it is perpetual in law or in practice) there should at least be some ceremonial attached to it to impress this fact on the minds of the participants and witnesses-something like the old English custom of feoffment with livery of seisin, where the conveyance of land was symbolically but forcefully evidenced, for instance, by the handing of a clod of earth by the vendor to the purchaser (Ruoff 1961: 358) 一which suggests that if we must use English legal precedents we ought to use precedents from an age earlier than the present commercial one.

In a more fundamental way, such an attitude to land would imply that the English doctrine that all land is held under the Crown (or the Administration) is untenable here. Indeed, except to the extent that there may be unowned land in Papua New Guinea, the legitimacy of the position of the Crown or the Administration as in a sense the owner of the basic underlying title to land must be open to questionpossibly if there is no one to whom the ownership of land can pass on death the land ought to revert to the existing customary group that 
last exercised rights of ownership over it: this may be a difficult concept to define in legally meaningful terms, but that is no excuse for not making the attempt.

Another Western idea that may well not apply in customary thinking, or may apply in a very different way to the way in which it applies in Australia, is the idea that there is only a limited number of kinds of interests in land that should be legally recognised, and that these in turn ought to be fettered in some manner (so that they can, for instance, be granted only by deed). There appears, to take just one example, to be no logical reason why 'easements in gross' should not be created, or that certain rights should only be granted as easements and others only as licences (with differing incidents). It may be said that such limitations add certainty and convenience, but let us face itthe certainty is only for the lawyers, and convenience is not necessarily visible to the outsider. In fact, the whole of the common Iaw classification of property into real property and personal property, with chattels real occupying a sort of middle position, needs thinking out again in customary terms, and may prove to be really meaningless here.

Once we start to challenge Western preconceptions as to the basis of land law, it is difficult to know where to stop. The very structure of traditional society itself dictates change. Western concepts are essentially individualistic, whereas customary Papua New Guinea concepts are essentially corporate; land owned by a customary group is not owned simply by the living members of the group but by the past, present, and future members at the one time. If such a group already has a real corporate nature, why does not the law simply recognise it as such? -and if the interests of the ancestors predominate in relation to certain Iands, why should not this be recognised by setting aside such areas as being sacred to, or controlled by, the ancestors? Possibly we need not go as far as in India where 'idols' are recognised as legal persons with the right to own land, but there is no need for an alien, completely materialistic approach.

Certain reasons for customising the land law of Papua New Guinea are the same as those applicable to any body of law. There is the natural desire of any nation to have a legal system that is home-grown and adapted to national needs and aspirations, and not merely an import--witness the Australian move to abolish appeals to the Privy 
Council. More important, however, is the fact that the essence of viable law is acceptability combined with at least a degree of general comprehensibility. In a colonial situation, and to a limited degree even under independence, the law can be deliberately educative, but the more it fails to agree with the general idea of what is right and wrong the less likely it is to be obeyed or to last.

In addition, there is the crucial role that land plays and always has played in the lives and social organisation of the peoples of Papua New Guinea. The body of land custom is organic (in the sense of being a living part of everyday life) to a degree that probably no other body of custom attains to. To be without one's land or land tights is more than just an economic loss-it is an important psychological trauma. The divergences between land 'law' and land 'custom' are thus far more than just differences between codes of law-they are differences between ways of life and attitudes to life.

If the land law is not reasonably acceptable and does not reflect the realities of land usage, it therefore rapidly ceases to have any but the most formal characteristics of law: it is simply ignored in favour of rules with more claim to legitimacy.

This is almost precisely what happened with the Land (Tenure Conversion) Ordinance 1963-1970, under which, by agreement of the customary owners, customary land can in theory be totally alienated from custom and vested by law in an individual. At the start, it was acclaimed as an answer to the problems of the emerging village entrepreneur and of rural village economic production. In practice, the result of ten years' work is negligible. More to the point, however, in one case that I know of (I have no reason at all to suspect that it is unique, but rather the reverse) the people officially agreeing to a conversion to a title held in the name of one man made it unofficially quite clear that while they appreciated the 'legal' position the 'real' position would continue to be as before. The moral of this case, and the basic justification for customising, is that in fundamentals society moulds the law and not vice versa-to change the law you first change society.

None of this, of course, means that the custom by reference to which we might customise the land law should be the custom of a hundred 
years ago, or of fffty years ago, or of first foreign contact, or of the present. There should be foom for new development in response to new needs, and in fact there must be such development. But what is needed is the development of a known theme-not the imposition of an alien one which natural forces will inevitably twist into a form unimagined by the original imposer. English legal history alone offers numerous examples of laws that worked in their time and are closer (because of the simple logic of land use) to present Papua New Guinea practices.

Let us look at some examples, starting in each case with an example of the usual sort of dogmatic statement against customising.

We must have certainty of tenure, which involves registration, which is impracticable with traditional tenures and shifting cultivation. Must we? To this day there remain in England, admittedly in vestigial form, patterns of shifting cultivation in which the fee simple (I use the technical expression advisedly) changes its physical position from year to year but is still registrable (Ruoff 1961: 539). In any event, shifting cultivation occurs within a group-ownership pattern, and if the individual ownership is not registrable, why should not the group ownership be?

For economic production we need individualised tenure, which is incompatible with traditional tenure. Do we? The English economy seems to survive with a doctrine of the Crown as the basic owner; with perpetual or long-term leases, perhaps at a peppercorn rental; with a system of impersonalised communal tenure by corporations. I leave out of account the fact that a very large part of the world seems to get along very well indeed-as far as the land law and economic production are concerned - with little or no individualised tenure. In any event, even if the proposition is acceptable, it is not land law but land use that needs changing. The most that the law can do is to facilitate, or at least not prevent, change when the need for change is generally felt.

Communal tenure stilles initiative. This of course is a statement of social and political philosophy, and not a legal one. In world terms, it is hardly worth thinking about. But communal tenure and a degree of individualised tenure are by no means incompatible-the question is 
one of degree, which can only be settled for a particular place and at a particular time. Proponents of the theory seem to have settled for eighteenth-century England and nineteenth-century America as the chosen place and time for all times and places.

Loan security is essential for development and land is the only satisfactory security-this cannot be provided for under custom. As a purely legal statement, this could, for a number of reasons, be most kindly described as utter balderdash. That loan security is essential for development is again primarily a statement of a particular social and political philosophy, at least in its application to the individual. That land is the only satisfactory security is a banker's shibboleth, which in any event is true only while land values are increasing or at least remaining steady in real terms. This is admittedly the case at the moment in the Western world. Part of the argument seems to be that personal security is risk security because the individual may die, etc. But custom recognises corporate landholding entities, the problem being simply that the law is not customised or sophisticated enough to recognise them. The third part of the proposition is true only to the extent that the law has not developed custom to an extent cognisable by Westernised lending agencies. It also gives a good opportunity for indicating what might be done if we stopped trying to adapt the needs of the people to the forms of the law instead of working the other way round ( $I$ assume for the moment that some sort of security over land is a necessity).

Why not have, for instance, instead of a conventional mortgage, a vifgage, which meant that

a person borrowed money of another and granted to him an estate to hold till the rents and profits repaid the sum borrowed with interest. The estate ... [being] conditioned to be void as soon as the sum was realized.

Or a Welsh mortgage, which meant

a conveyance of an estate redeemable at any time by the mortgager on payment of the loan, the rents and profits of the estate being received in the meantime by the mortgagee, in satisfaction of interest (Jowitt 1959: 1842 and 1856). 
At first glance these charges may seem mere historical oddities, but they happen to coincide closely with traditional Tolai customs.

There is no mortgaging of land in the European meaning, but pledging of land was a pre-European custom. When the person was temporarily unable to repay a loan of tambu [shell money] (or now money) he could give the lender a piece of land as an earnest of his intention to repay. The lender could then plant gardens on the land, or collect the produce of trees already planted there, for as long as the loan was not repaid. When the loan was repaid the use of the land for gardens, and the produce of planted trees, returned to the pledger (Smith and Salisbury 1961: 11-12).

It is only by a historical accident-actually the expulsion of the Jews from England (see Pollock and Maitland 1952, vol. 2: 124)that Australia did not come to Papua New Guinea with a legal process to which custom (at least Tolai custom) might have been assimilated.

Even without abandoning what is at the moment our basic legal set-up, English law both present and past has such a rich heritage that it is not legal precedent that has been wanting to customise our land law, but legal imagination.

But why play around with the present situation when custom now applies to about 97 per cent of the land of Papua New Guinea, when it is not only enforced as law but officially recognised by Section 4 of the Native Customs (Recognition) Ordinance as being more capable of development and adaptation than even the received common law? It is unlikely that a self-governing or independent Papua New Guinea will accept a legal situation in which the alienated and economically most significant 3 per cent of the land is regulated entirely by an alien legal structure. Besides, admitting that custom can and does develop naturally to meet new needs, it is inevitable that the Government will want such development to be planned and regulated by it to a large extent. Left to itself, custom is unlikely to develop institutions and procedures suitable for some government purposes (for instance, for the purposes of land tax, if this be desired as an economic or policy measure). More importantly, however, the history over recent years of disputes as to customary land (for instance, in the Western High- 
lands, where killings over land disputes are commonplace) is not such as to lead any government to place much reliance on the unaided self-regulating powers of custom.

What limits are there on the possibilities of customising? I doubt if this question can be properly asked in advance of detailed investigation. The real question is the limits within which any land law must operate. The answer, in so far as it can be given at the moment, seems to lie in three propositions: first, such as they are the existing guarantees of title should not be upset; second, the system must provide for whatever level of guarantee of title is needed to meet economic requirements; third, customising is an exercise in land law reform, not land tenure reform.

As Crocombe (1971a: 375) has pointed out, the direction of land tenure reform is dictated by social context and goals and so, of course, is the concept of 'economic requirements', but it is just not possible for me, as a lawyer, to accept Fleming's bland statement (1971:27) that the comparison between customary and imported tenure systems

is not favourable to customary law. The indigenous farmer sees the expatriate settler protected by a registered title guaranteed by the State on which he can borrow money and develop his land. On the other hand, customary law knows no form of individual ownership and restricts the occupant's right to deal with the land and it is not possible to borrow on its security. Moreover, the occupant's rights and interests are subordinate to those of the family or the clan and development in accordance with modern or improved farming practices is almost impossible.

The contribution of a lawyer committed to customising would be to ensure that whatever changes in the law are necessitated by social policy or political philosophy, they should reflect local practice as far as possible, and should deviate from it as little as possible. But before tackling this task, a firm decision by the Government to customise is needed. Moreover, we need to have digested into a legally-relevant form the immense amount of research already done (not only by academics) into land customs and attitudes in Papua New Guinea, and to have isolated the general customs and attitudes of significance to the lawyer. After this process of digesting and the filling-in of any 
gaps shown in the process, a comprehensive review and restatement of the land law should be undertaken in the light of the results. In short, here is an exciting and potentially fruitful field of co-operative effort for politicians, administrators, lawyers, and behavioural scientists. What is undoubtedly required is early action on facts already known. 


\title{
Technical law and the outside expert
}

\author{
D. J. Whalan
}

The fact that I am writing this paper already suggests that I feel there is a role for the outside expert at the present stage in the history of Papua New Guinea. I do. But it is not for any ousider, however expert or inexpert he may be, to decide if there is to be such a role or what that role is to be. Those decisions are for Papua New Guineans alone. Nevertheless, it is essential for anyone from the outside who is asked to help, even if he is not told, to repeat to himself a dozen times a day that his role must always be an advisory and not a decision-making one, and then to act accordingly, especially if he deals with land problems.

Scratch a Papua New Guinean and you find a person with an actual or potential land problem. This is inevitable because of the central position land has, and will continue to have, in Papua New Guinean life. For many years the people will be directly dependent on the land whether as subsistence gardeners, commercial farmers, or mineral producers. Furthermore, an economy based on primary production, much more than one based on secondary and tertiary industry, requires that the land law should give a secure and accurate title that can, if needs be, be dealt with speedily and inexpensively.

In the resolution of these problems there is a place for the specialist's advice. For not only are Papua New Guinea's land problems complex, but the possible solutions are excitingly open. The political, social, and constitutional situations are going through a stage of rapid change and this fluidity may be a positive advantage in the adoption of appropriate policies in all sectors, including the crucial land policy area. Clearly the likelihood of imaginative and substantial changes being adopted by a government and accepted by the people is greater in a stimulating atmosphere of change. Although enthusiasm and a willingness to try new ideas are important, they are not enough. Before political decisions and the resultant legal and administrative changes 
are made, those making the decisions must assess the various possibilities, and in making theit judgments it may be advantageous to have the advice and assistance of specialists.

Expert advice can be sought in almost every social, political, or economic development that is made. And, of course, in many fields of endeavour such expertise is already being sought. But I would stress that there must be co-operation with and among experts not only in presenting the possible directions in which policy can go, but also in devising the machinery to carry the chosen policy into effect. Indeed, I feel that one of the most important needs is for everyone-the people whose problems are under scrutiny, their political representatives, as well as administrators and all kinds of specialists-to get on the same wavelength and stay on it. This applies to land considerations probably more than to any other area.

In this we can perhaps learn from the experience of other emerging nations. I believe that there is evidence for an unfortunate cyclical pattern: advice is sought on sorting out the land problems; specialists are engaged; an inquiry is conducted and recommendations are made; legislation is enacted, giving at least partial effect to these recommendations; the legislation is brought into effect and appropriate practical procedures are instituted-the final part of the cycle is completed about ten years later with a new request for advice on sorting out the land problems.

Often the principal cause of failure was that insufficient manpower, money, and other resources were made available, so it is not possible to assess whether the suggested policies would have been adequate if given a proper chance. But very often it also seems that a panacea was being sought from specialists in one discipline alone and that only the one device of legislation was recommended. Perhaps more significantly, hindsight frequently shows a divergence between the adopted policies and local needs and aspirations. Recent experiences have been happier, but Papua New Guinea can learn from the failures as well as from the successes that have occurred over the years. For, although this cyclical pattern is not quite so patent, something like it is evolving in Papua New Guinea and there must be a break-out from this orbit if the land problems are to be solved. 
Though much can be learned from experiences elsewhere, the dangers of transplating ideas or legislation must also be guarded against. On occasions the Westminster style of parliamentary democracy has not transplanted well; this is so too with some aspects of the English common law system; and one of the aspects that has created problems is English land law. Just as the human body may reject transplanted body tissues because they are incompatible, similarly a rejection of law that is foreign to the body politic may occur. But, to carry the analogy further: provided that careful matching is achieved, the body does accept certain transplants and in doing so is made stronger or cured of an illness. Perhaps the people of Papua New Guinea may accept certain suitable or suitably adapted elements into their legal system and thereby strengthen it. In both cases great care is needed in making the choices if the 'patient' is to benefit. Applying this to the land law, the problem may be to decide which aspects, if any, of a particular law-English or otherwise-may be valuable in Papua New Guinea; in what circumstances and areas they may be useful; and in what ways they must be altered to ensure compatibility.

Another medical analogy may be even more relevant. A doctor looks at the patient's symptoms and reaches a diagnosis before he attempts a cure, lest in alleviating the symptoms he masks the true nature of the illness. Having reached his diagnosis, however, a doctor prescribes the best possible medicine to effect a cure and follows through to see that it is achieved. This is also applicable to Papua New Guinea's land problems. It is hoped that the policies that are presently being evolved are consistent with this analogy of rigorous diagnosis and persistently pursued treatment. There is no 'miracle' cure, but solutions can be developed that will, in time, be effective. It may be that sympathetic outside experts from various disciplines have a contribution to make at the various stages in what will be a slow curative process.

As far as the legal expert is concerned, his most important contribution is naturally to advise on the technical aspects of the law. For it must be remembered that any modern legal system, even if it is strongly based on custom or traditional values, poses a number of technical problems which require technical solutions. On the other hand, and legal experts like all technical advisers (including doctors) are often reluctant to admit this, there are usually a number of 
possible solutions to a technical problem. Moreover, many of them can be modified in such a way that they lead to very similar results, even if the starting points appear to be different, or to very different results although the starting points are very similar. For this reason in particular it is essential that there be a continuing dialogue between political decision-makers and technical experts if satisfactory results are to be achieved. Policy-making and implementation are not separate spheres. This also applies to the design of the general legal and administrative machinery for implementing policies. Close co-operation between the people, politicians, and experts is needed right up to the final drafting stage.

I turn now to one quite technical land law problem which illustrates some of the implications of these general remarks. This problem is bound to arise if any major program of legislation to reform the land law is undertaken in Papua New Guinea. Indeed, the problem did arise, and in my opinion was not adequately solved, in the 1971 land bills. Although I emphasise that this problem is merely one technical aspect of one segment of the total land problem requiring solution, it will be a very important one if legislation is introduced altering the present basis of the land laws to the same extent as, or to an even greater extent than, the 1971 bills did. This is so whether this change is to take place throughout Papua New Guinea or only in a few selected areas. It is the problem of the 'back-stop' law that is to be behind any statutes that may be adopted.

Where legislation introduces novel concepts there is always the task of defining the relationship between the new Acts and the existing general law. Even where the new Acts are superimposed on an existing set of laws, there can be considerable difficulties in settling the relationship between the 'new' and 'old' laws, but where legislation is introduced which changes or negates the whole substratum of the law it is superseding, then the problem is greatly magnified. I would suggest that the Torrens title statutes introduced in Australasia (or for that matter the Torrens-based statutes in force in Papua New Guinea) are of the first kind and the Kenya Registered Land Act 1963 and its related Acts are an illustration of the second and much more radical kind of change.

Whatever kind of legislative proposals are adopted in Papua New 
Guinea, I believe that the legislation should make clear what the 'back-stop', 'back-drop' or 'base' law is to be: that is, when a hiatus or gap or any difficulty of interpretation becomes apparent, the legislation itself should make clear the source to which the interpreting court or other authority is to turn in order to solve the difficulty.

An apparent dichotomy has arisen between the view of those who support the proposition that the English law of real property is unsuitable for developing countries and must be replaced with a new and simple set of statutory law and the view of those who argue that there are dangers in substituting a body of unknown and untested statutory law for a body of fully developed law. The former point to the incongruities that sometimes occur in relating English land law concepts to local conditions and the latter argue that, if a new law with so many fresh concepts and technical terms is introduced, land owners may well be exposed to the hazards of a long series of costly judicial interpretations.

I have some sympathy for both views, but I have a feeling that either there is no real dichotomy or, if there is, it can be removed. I agree that the unnecessarily complicated rules about property and limitation that English law has developed are often unfortunate in a developing economy ${ }^{1}$ and that there is much truth in the following unmerciful description of English land law by R. R. Torrens (1859: 4):

Lord St Leonards . . . speaks of the . . . law of real property as 'exhibiting a splendid code of jurisprudence'. Possibly . . . it . . . [is] altogether too splendid and ingenious a work of art to suit either our means or our requirements in these colonies; that ... the proper place for this 'splendid code' is the cabinet of the antiquary, where those who have leisure and a taste for that sort of thing, may admire this proof of the vast powers of the human intellect, however vainly or preposterousiy employed'. In playing out the game of life in this work-a-day part of the globe, we require something less costly, something less artificial, something which we may handle with more freedom and rapidity.

1 This theme is developed at some length, with wit and devastating logic, in Rowton Simpson 1969. 
Of course, in many Australasian jurisdictions there have been modifications in, or the abolition of, such rules as springing uses, estates tail, and estates by wrong, and we are untroubled by 'weakkneed remainders without an antecedent estate, or limitations of chattels real without a trust ... scholastic "possibilities on possibilities" stalking through modern daylight ... and estate clauses barren of estates ... (Duffy and Eagleson 1895: 7). But, even where the rules have not been altered, their effects have been avoided by doing two things, and in these two lies the resolution of the apparently opposing views.

First, the Torrens system of registration of title was adopted. In a characteristically intemperate outburst Torrens exclaimed in 1857 that the old system of English land law

could not be patched or mended: the very foundation was rotten; therefore it must be cut away and a new system substituted. Like a blundered calculation on a slate, it was in too much confusion for correction, so he would take a sponge and rub the whole out.

Unfortunately, his performance did not match his promise, and the Torrens system had to be backed up with land laws that removed or ameliorated the absurdities-and the legislators were careful to leave English land law to act as a back-stop to fill the gaps.

Second, and the importance of this matter has often been overlooked in Australasia, the community has simply negated the effect of much of the English land law by failing to use it. For instance, seldom, if ever, will anyone in Australasia have met that exotic animal a tenant in tail male after possibility of issue extinct. In other words, the most technical doctrines of English land law never obtruded themselves, for in Australasia landed estates have never been tied up in the English manner in strict settlements, ${ }^{2}$ but land has been treated as any other commercial commodity and bought and sold as such. This commodity concept approach has meant that the difficult doctrines of English law have fallen into limbo, as transactions tend to be of a simple nature. Nevertheless, when a doubt or difficulty has arisen there

2 As late as 1875 some two-thirds of England were tied up in strict settlements which prevented the life tenants from selling: see Brodrick 1881: 100. 
has always been the back-stop of the English land law to deal with it.

In Papua and New Guinea, too, transactions affecting land will probably be restricted to the same conceptually simple transactions that have been characteristic of Australasia. Yet, in considering any proposed legislation, there must be an awareness of possibilities as well as probabilities - the theory as well as the actuality-and the resolution of the problem of the back-stop law becomes of crucial importance. For no one framing legislation on such a topic can hope to think of, and cover, every eventuality.

The 1971 Registered Land Bill did, for example, deal with the complicated English law principle of consolidation and with the future advances doctrine. But there is a myriad of possibilities that were not covered. As I have just suggested, most of these will not arise regularly, but many have arisen, and their application has been resolved, under the Torrens system legislation. Furthermore, there are some practical problems that could arise that were not covered. For example, the possible relevance of the doctrine of 'waste' could very well arise in the circumstances existing in Papua New Guinea. In addition, there is the side effect problem that, if legislation does deal with some specific principles, then the courts may hold that, by implication, the intention was for the treatment to be exhaustive and that other principles are therefore excluded. Thus, if it is decided to proceed with legislation in Papua New Guinea, which makes fundamental changes in the land law, it is essential to settle the question in anticipation by providing in the legislation itself for some kind of back-stop law.

In attempting a resolution between such a 'new' law and the 'old' law there seem to be at least four possibilities. (One further possibility would be to retain custom as a back-stop in some form, either in place of English common law or, perhaps more likely, by using customary principles in the interpretation of an 'equity and good conscience' clause. However, I do not feel competent to assess this possibility so I can only emphasise that it should be carefully considered by those who are.)

The first possibility is that the precedent set in the Kenya Registered Land Act 1963 could be followed. Although it has been suggested that this Act 'establishes a complete code of Property Law' (Rowton Simp- 
son 1971: 15) -and, for most practical purposes it does do so-it is submitted that as a matter of legal theory it does not do so. Indeed, it does not purport to be such a code. Section 163 lets in the whole of English common law and equity where a point is not specifically covered either by the Registered Land Act or another statutory provision.

If this solution were adopted it is suggested that it would itself raise the problem of just what the provision would cover in Papua New Guinea. This question of deciding what are the appropriate received rules of law in Papua New Guinea has caused difficulty in the past and, although litigation and specific statutory enactments have delineated and reduced the difficulties, I would certainly not be brave enough to attempt to answer the question for all circumstances (see Lynch 1969: 39). Thus it is perceived that, although this may very well be an adequate solution to the problem in Kenya or other jurisdictions where the problem of received law may not cause problems, this may not be the best possible solution in Papua New Guinea.

At the other end of the scale a provision could be based on section 230(1) of the British Solomon Islands Protectorate Land and Title Ordinance 1968. In this provision a very clear and deliberate intention is shown to constitute the Ordinance as a complete code. The court is given very clear directions to interpret its provisions in the spirit of the enactment and without recourse to any outside body of back-stop law, English or otherwise. Such a provision does place a very heavy responsibility upon the judiciary, and indeed in some circumstances the court could be virtually filling a policy-making tole. But several very important exceptions from this absolute code position are set out in subsection 2 of this section: the general rules regarding trusts, wills, the administration of the estates of deceased persons, bankruptcy and incapacity are to apply.

There is a middle way between providing that an act is a complete code or letting English law remain unfettered as the residual law. This middle course is, for instance, adopted in section 160 of the Malawi Registered Land Act 1967. In this provision the very great difficulty in setting up a complete code is conceded, but the device of selecting a specific set of completely developed law, which may or may not prove suitable to local conditions, is avoided by conferring on the interpreting 
authority jurisdiction to decide any issue not specifically dealt with by legislation 'in accordance with the principles of justice, equity and good conscience'.

This provision, too, imposes a heavy burden on the body interpreting the law, but it avoids binding a court to follow a specific set of perhaps inappropriate decided laws while permitting it to borrow concepts or a developed body of principles from other legal systems if these are felt to fall within the 'justice, equity and good conscience' precept.

In diffidently suggesting a further possibility, I am really not putting forward any simple solution, for I doubt if there is one. What I am suggesting is that we should look at the three possibilities canvassed so far-and in some way select the best and exclude the worst features of each.

I believe that a possible answer lies in legislation along these lines. First, the best concepts of which there are many in my view, would be taken from the Kenya-type acts. These would be melded into a background of the best of the Torrens-type acts which, even if their wording and general drafting leave much to be desired and can be improved upon, have been subjected to judicial scrutiny for more than a hundred years in Australasia and Canada particularly. On some points advantage could well be taken of appropriate ideas in the English and Malaysian Acts as well as the Australasian and Canadian ones. Then many of the parts concerning general property law (as opposed to registration and procedural) that are presently at large in the jurisdiction would be reduced to statutory form; adaptable draft provisions for many of them will be found in existing conveyancing or property law acts in other jurisdictions but perhaps more points could be covered. Ideally these provisions should be contained in the same legislation instead of, as in most jurisdictions, in separate acts, but this point is not vital. Indeed in the situation of non-total area coverage which is bound to continue for some time there may be some advantage in having a separate act of more general application. Finally, the ultimate back-stop could possibly be the very much reduced ambit of English common law and equitable provisions or a justice, equity and good conscience' kind of provision. Whichever is chosen, it will cover a very much smaller residual area than does any present legislation, but I have a strong preference for the justice, equity and good 
conscience' provision as the better alternative for covering this small ultimate area.

I believe that every endeavour must be made not to leave a hiatus in any major program of land legislation that is undertaken. It will be seen that I am not offering a simple, short formula for solving this back-stop law problem. I do not believe that there is one-just as I do not believe that there is a short cut to solving any of the other land law problems of Papua New Guinea. But just as I do believe that with great care, patience, industry and goodwill the present enormous difficulties can be reduced to insignificance, even if they are not eliminated, so this small segment of the problem can be reduced to comparative unimportance by the production of a much more comprehensive scheme of codification than I believe has yet been attempted. 


\title{
I I A banker's gamble
}

\author{
R. J. Gunton
}

The Papua and New Guinea Development Bank is taking a multimillion dollar gamble in one aspect of its lending. In 1972 the Bank had been in existence for about five years and in that time had made loans totalling approximately $\$ 4$ million under what it calls Clan Land Usage Agreements. This type of lending has expanded rapidly and it is hoped that the high rate of increase can be maintained in the future.

Most of the land in Papua New Guinea is owned by the clansthat is, held according to native custom. It is worth devoting a little space to discussing in fairly general terms what this entails, the Highlands region being taken as the extreme example. The local people have discovered over the centuries that the forest regeneration cycle is relatively constant. Depending on the type of country and climatic conditions, it ranges from about seven years to twenty years. Suppose the cycle is fifteen years and that the individual gardener in any one year will work three small plots of land. Commonly, one of these will be close to water, another, probably also of reasonable fertility, removed from the water, and the third on a hillside, possibly very steep and not very fertile, used mainly for growing sweet potato. In the fifteenyear period the individual may therefore use as many as forty-five separate pieces of land. Obviously this single fact makes for great complexity of usufructuary rights and can lead to much dissension within the clan. However, there are other complicating factors.

While one man may have the usufructuary rights to the land, another may have the right to gather sticks when the land is not being cropped. A third may own the pandanus palms growing there. (These, incidentally, have an almost holy status in some parts of the Highlands where, for centuries, the diet has been grossly deficient in oils and fats, and disputes over the ownership of the pandanus and the right to gather its nuts still lead occasionally to bloodshed.) Further, the right to cross the land in the course of their affairs may be reserved to some members of the clan only and not be available to others. 
The consent of many people may be required if one person is to have exclusive right to the land for a project such as the raising of beef cattle or the planting of tea, coffee, pyrethrum, and so on. Of course, this makes a very strong argument for the demarcation of the clan's land and subdivision and tenure conversion into freehold lots. However, it is still quite common that the borders of the land of adjacent clans are in dispute so that the first step in the long process of tenure conversion cannot be taken.

The Development Bank would not contemplate lending for projects on disputed border land but has decided that, if its rural lending is to proceed at an acceptable pace, it must lend on land that is not subject to inter-clan dispute. In taking this extremely bold decision, the Bank was aware that it had established something of a world-wide precedent. Exhaustive inquiries failed to reveal another development bank rural lending program which could serve as a guide in avoiding the pitfalls assumed to be inherent. World Bank and United Nations missions have professed astonishment, not to say dismay, on first learning that the Papua and New Guinea Development Bank lends for rural ventures on land over which it can take no charge. To date, it has proved possible to reassure these people because no major problems have arisen from the clan land lending progtam. The future may tell another story and this will be discussed briefly below.

The Bank's network of branches, representatives, and agents is spread widely across Papua New Guinea and used actively to promote rural lending. The Bank makes extensive use of the facilities of the Department of Information and Extension Services, particularly in such radio programs as 'Toktok long Didiman' which is roughly the equivalent of the Countryman's Session on the A.B.C. Also, schools and vocational centres are visited regularly for talks about the Development Bank, its functions and objectives and its lending policies. Some fairly limited use is made of the popular press. In all of this it is made clear that the Bank will lend for projects on land held according to native custom. Notwithstanding these efforts, the Bank is not as yet besieged with an unmanageable flood of applications for loans. Indeed, many applicants have to be persuaded of the desirability of borrowing. 
When an individual, whether by persuasion or of his own volition, has approached the Bank for a loan to start, say, a smallholder cattle project on clan land, the first step is to establish with the local demarcation committee that the land in question is not subject to inter-clan dispute. Given that it is not, the process of drawing up the Clan Land Usage Agreement is begun. Clan leaders are consulted and it is made clear to them that the clan must confer on the borrower the right to sole use of the land during his lifetime. When the leaders have consented, they are required to advise everyone who has any claim whatsoever to the land of what is proposed. This may be a tedious and long drawn-out business because the Bank officer or the agent handling the application will not have the Clan Land Usage Agreement signed or marked by the clan leaders until he is sure that what is being proposed is fully understood and accepted.

There are three factors here. The first is the well known communication problem in Papua New Guinea; there are over 700 languages spoken in the country, all of them by comparison with English having a very restricted vocabulary. If the man, not necessarily a European, processing the loan does not speak 'place talk'-that is, the local language-he must use an interpreter and many repetitions will be necessary before he accepts that what is proposed is understood. The second factor is that in most rural communities not much importance attaches to the passage of time, the people enjoy thrashing out things in the minutest detail, and the whole affair is momentous enough to be savoured as long as possible. The third is that the loan applicant generally will have to make arrangements with those whose land will be incorporated into his lifetime holding. This will involve the exchange of gardening rights, stick gathering rights, and all the rest.

In the course of the foregoing, the Bank's man will have been conducted repeatedly over and around the boundaries of the project land. Of course, the boundaries themselves are not normally surveyed but are typically defined in the following fashion: 'From the bend in the creek to a given tree to a well known rock shaped like a man's head to the big tree with three forks... [and so on] back to another point on the creek.'

The polygon so defined sometimes has a great many sides but it seems to be generally accepted that these must be straight lines. In cases where 
it is suggested that the boundary should run from point $A$ to point $B$ but not include something which lies within the boundary, an additional apex excluding the object or area in question is sought. The form of the Clan Land Usage Agreement is shown opposite.

Note that the form requires a sketch plan of the piece of land. Sometimes this is omitted but it can be safely assumed that, when the form is signed, the clan knows the specifications of the land to the square yard.

As something of an aside, it is interesting that the Bank may require no cash equity on the part of the borrower for a smallholder cattle project, 'smallholder' implying indigenous without exception. Once the land is defined, the borrower makes his contribution in the form of 'sweat equity', a most expressive term borrowed from the people of the International Bank for Reconstruction and Development. If the borrower will clear the land, erect fence posts and build yards, the Development Bank will provide the rest including, of course, the cattle. For tree-crops a somewhat different procedure is followed, namely, the ' $4 \frac{1}{2}$ to 1 rule'. If the individual plants up two acres of, say, cocoa or coconuts, the Bank will finance a further nine acres. Nothing very significant attaches to the ratio; it arose from long discussion about what constituted an acceptable equity and probably is a compromise between 4 to 1 and 5 to 1 on the basis that the former was a bit too liberal and the latter a bit too stringent. In the case of both, sweat equity and the $4 \frac{1}{2}$ to 1 rule, the Bank is seeking to satisfy itself of the borrower's capacity for work and willingness to undertake it.

To date there have been no major problems arising from clan land lending. For any bank, the main problems in lending are substantial arrears of repayments and outright default. Clan land borrowers certainly have a record no worse in those respects than the Bank's other clients and in fact one that compares very favourably with rural lending in other developing countries. Nevertheless, from a conservative banking point of view, the security is atrocious and amounts to nothing more than a stock mortgage. If a smallholder cattle borrower made the decision to default and slaughtered his stock before the Bank became aware that the loan was in jeopardy, the chances of the Bank's recouping would be slight. What is quite evident is that it has absolutely no power of disposal of the land because the borrower has 


\section{CLAN LAND USAGE AGREEMENT}

Date.......

To the Papua and New Guinea Development Bank.

We, the undersigned, being representatives of the

Clan, hereby acknowledge that

has the right under native law and custom for the whole of his lifetime to use the land known as .................................. (or more partictilarly described in the plan on the reverse bereof) for the purpose of ................................................................................. the proceeds of crops, trees and palms grown, livestock grazed and/or business conducted on the said land. We certify that all members of the said clan agree to the truth of this certificate and that we are the persons authorised by the clan to sign it.

Witness

Witness
Full name of Clan Leader

Full name of Clan Leader
His Signature/Mark

When term of loan exceeds 5 years one of the sections below must be completed in addition to the above.

As Chairman of the

Dewarcation Committee,

I am of the opinion that the above Clan is not prevented under sative law and custom from giving the above certificate and that the signatures/marks are made by persons authorised to commit the Clan.

Witness

Full Name

Signature/Mark

$O R$

As Clerk of the

Local Government Council, I am of the opinion that the above Clan is not prevented under native law and custom from giving the above certificate and that the signatures/marks are made by persons authorised to commit the Clan.

Witness

Signature/Mark

Affix stamp of Council here

OR

...Local Government Council, I certify that a formal record of claimed rights in accordance with the above certificate has been recorded by the Council under the provisions of its Land Use Record Rule. 
no legal title to it, nor does the Bank have the power to dismantle and remove any structures erected on the land. However, clan land projects typically are a source of pride and prestige to the entire clan as well as to the borrower, who is therefore under some pressure to meet his repayment schedule.

Two problems can arise in the future, both concerning the successful borrower. A very successful borrower who wishes to expand his project may, because of the jealousy and envy of the clan, be refused access to additional land. Moreover, the borrower who has grown large by his own efforts and with further financial assistance from the Bank may find his possessions and even his person at risk. Probably it will depend largely on the successful man's willingness to share his affuence, but there may be other factors. Sorcery is still very much a part of the lives of the great majority of Papua New Guineans and the Bank is aware of instances in which it has been claimed that the prospering smallholder has had supernatural assistance, and of other cases where sorcery has been invoked against the man thought to be enjoying undue success. In one subdistrict the house of a man who was obviously doing much better than his neighbours was put to the torch, part of his fences were destroyed, and some of his trees damaged, while threats were made against his person. In another part of the country an indigenous borrower who had developed to a very large scale of operations travelled and slept with a loaded shotgun at his side.

As a general rule, it is probably true to say that the 'big man' who shares his success with the clan in what is regarded as a satisfactory way will be a source of pride and relatively little discontent. However, there is mounting evidence in Papua New Guinea, as in other developing countries, that while the extended family system is acceptable in conditions of more or less uniform poverty, the person whose larger income must be shared among distant relatives and unrelated clan members, together with the person whose accumulation of assets is severely inhibited by the extended family, are becoming increasingly disenchanted. There are two forces here, working in the same direction to restrict development, namely resentment of the individual who does not adequately share his greater income and wealth and the individual's resentment of a social structure that obliges him to share.

The Development Bank is well aware that sometimes the brother's 
coffee or the cousin's cocoa helps to pay off the cattle loan. Whiere the individual's affairs have grown large, and particularly if he has not discharged his social obligations to the satisfaction of the clan, assistance with repayments is not likely to be forthcoming. In these circumstances it may be that the clan will have no difficulty forgetting that the borrower was once a source of pride and will actively seek his downfall. This is only to suggest the possibility, not to prophesy the certainty, of greatly increased problems of default and arrears of repayments as some borrowers expand their operations. The experience to date is encouraging but cannot be taken as a firm guide to the future, and it probably is true that no one knows how individuals and groups will react to failure of large ventures on clan land.

In respect of land tenure in this country, the Bank's lending program on clan land may be held to be both a good thing and a bad thing. As it becomes accepted that the Bank cannot lend on land which is in dispute, there will be a stronger inducement for neighbouring clans to settle their differences. The highly ritualised, inter-clan warfare typically is carried on in the valleys while, for security reasons, the villages are built on hilltops. This normally means that the most fertile land is the scene of fighting and, of course, is the land in dispute. Realisation that the most fertile areas cannot be the basis of Bank lending could lead to fairly rapid decisions on permanent clan boundaries. This obviously would be desirable. Working against it is the knowledge that it is possible to borrow for projects on some clan land and therefore there is less pressure to subdivide it into individual freehold blocks. If all land in Papua New Guinea were Crown land or freehold, then the Bank's security could be greatly enhanced by taking a charge over the land and, presumably, the already high rate of increase of rural lending could be accelerated, subject only to the availability of adequate extension services.

In Kenya, Jomo Kenyatta had the prestige and courage necessary to force a program of tenure conversion. It is difficult to believe that rationalisation of land tenure in this country can be postponed indefinitely but it will be a brave House of Assembly that initiates the process. Taking a very long view, the Bank must accept that the developmental effect of its clan land lending may be partly counteracted by reversion of land to the original users on the death of borrowers. 
The man who travelled with the shotgun died recently and it is said that there are several hundred claimants to his estate.

The Development Bank believes that its innovatory clan land lending is in the best interests of Papua New Guinea; we hope the future will judge it so. 


\section{I2 Destruction or adaptation}

\section{C.W. Kimmorley}

There are people who will assert that native society in Papua New Guinea has few institutions, and that those which do exist should be done away with and replaced by better ones. By 'better' ones, such persons usually mean institutions familiar and acceptable to them. Even if this attitude is not consciously held, in practice something very much like it must have prompted the makers of government policy for this country, for Administration offcers have often been intent on introducing new institutions and ways of life, with little regard for those already in existence. They have mostly done this with the best of intentions 'for the good of the people', and because existing institutions have been considered of small value, it has been assumed that they can be discarded, with little effect on the lives of the natives.

But native institutions affecting land tenure, marriage, sanctions for maintaining order, and so on are not things of little worth, and the people are loath to let them go. They are only not well understood by Europeans because they differ from their own ideas and so are not readily apparent to them. This is unfortunate since it has been known for a long time that in governing people, whether the government is an outside one or of the people themselves, the greatest degree of acceptance of new ideas will be achieved if they seem familiar.

In The Discourses Niccolo Machiavelli wrote:

He who desires or attempts to reform the government of a state, and wishes to have it accepted and capable of maintaining itself to the satisfaction of everybody, must at least maintain the semblance of the old forms: so that it may seem to the people that there has been no change in the institutions, even though in fact they are entirely different from the old ones.

Many of those concerned with government in Papua New Guinea appear to have largely overlooked this principle and to have acted as though the destruction of existing institutions is better than their adaptation. They thought that the mere assertion that a new institution 
is superior to an old one should make the people immediately adopt the new institution although they themselves would strongly resist new doctrines, no matter how often they were assured that they were for their own good.

It is unusual to find a piece of land in Papua New Guinea which is owned by a single person, except in some places such as the Tolai area near Rabaul, where native custom has been modified so as to let individuals have plots of their own for the planting of permanent cash crops. As long as land is used for the traditional shifting subsistence agriculture, which necessitates leaving old gardens and making new, individual ownership offers no advantages. But it may become desirable when tree-crops are planted on a larger scale and the planter and his family wish to retain the land on which they grow for at least the period over which they will bear crops.

Land is usually said to be owned by clans. A clan's land consists of irregularly shaped plots, varying considerably in size, interspersed among the plots of other clans. Within the clan there are lineages which are similar in form to clans but smaller. Both clans and lineages consist of persons believed to be descended from a common ancestor. In the case of a clan this person is sometimes mythical, or the acts of several historical ancestors have become attributed to a composite person' who is regarded as the founder of the clan. The founder of a lineage is usually a real person, a man or woman only four to six generations removed. The land holdings of a clan are in most cases divided between its lineages, each controlling the plots which it occupies. This control is so strong that a lineage can even exclude members of other lineages belonging to the same clan from using such land. Should a lineage die out, its clan has a reversionary right to the plots it controlled.

This is the pattern in matrilineal as well as patrilineal societies. The lineage is the basic unit of a native society in all its aspects, including the ownership of land. The affairs of a lineage are, or were, decided upon in the 'man's' or 'club house' of that lineage, a place where drums, weapons, masks and emblems, etc. were kept, under the leadership of the lineage head, usually the senior male within it.

The policy for indigenous agricultural development in the past has had two main objectives: first, the purchase of land for resettlement 
and its division into blocks for leasing, and second, the encouragement of village people to plant cash-crops near their villages. Attempts to achieve both these ends have in many instances been objectionable to the natives in various ways.

The policy of using smallholder blocks, each settler residing on his own holding, has first of all gone against the native preference for living in a community of some kind. There appears to be no reason why new villages surrounded by fields or holdings could not be used as in Malaysia and Ceylon, except that the individual on his own land is an Australian ideal, dear to Australian policy-makers, who have naively assumed that it must also be good for Papua New Guinea.

The settlement of people on smallholder blocks is also a complete break with traditional work patterns, based on reciprocal aid within the lineage. In clearing or fencing land, building a house, making a canoe, preparing a feast or a ceremony as well as in many other activities, a person was aided by other members of his lineage and thereby became obliged to help those others to the same extent as they had helped him. This is not to say that individuals should not be allowed to work their holdings on their own, but resettlement schemes should also be designed in such a way that settlers can, with the least inconvenience, continue their traditional style of life and work if they so wish.

But there are other additional reasons why resettlement schemes have not been too popular and successful in the past. Many of the people removed from their own ethnic groups to resettlement blocks on land purchased from strangers are unhappy there because they are isolated and feel like interlopers on someone else's land. Moreover, many of the settlers are superstitious. They believe in spirits such as the masalai, which are associated with particular landmarks, for instance large trees, rock outcrops, or caves. In his own area a person knows the abodes and attributes of the local masalai-their malignancy or harmlessnessand is able to deal with them by avoiding or placating them. But he does not know them in foreign surroundings. He does not even know whether there are any in his vicinity, and finding an odd-looking stone on his holding, where a masalai may lurk, he will be frightened and barricade himself and his family in his lonely house at night.

The policy of getting cash-crops planted near villages, where these difficulties do not exist, has also not worked well up to the present. A 
number of government officers encouraging this form of planting have had little knowledge of native land tenure. They have assumed that land around a village is communal land and that anyone in the village may plant on it. In some instances people have been ordered to do so, and the resulting 'village' or 'government plantations', some dating from the days of German sovereignty, most from the period between the two world wars, are a prolific source of dispute. In these plantations members of many clans have planted land belonging to one or two lineages. The trees belong to the planter, making the land they grow on useless to those having ownership rights to it.

On Buka Island (and probably elsewhere) the people were suspicious about this type of planting. They feared that the land would be leased to a European after being cleared and planted, and therefore contrived to plant on land belonging to someone else. If their fears proved true, they would only lose their labour and the trees-if groundless, they would still own the palms, although they were not on their own land. In doing this they were helped by the fact that the German Administration had marked lengths of roads or tracks for each village to keep clean. These lengths were proportionate to the population of the village at that time, to ensure an equal distribution of work. After the Germans had gone, these lengths came to be regarded as indicating the extent of 'village land' along the road.

Latterly, instead of being ordered, the people have been advised to plant communal village groves, or individual plots in a compact area near the village. Often this advice was taken as an order, and again many lineages had to plant on another's land, because they had no suitable land near the village-with the land owners' reluctant assent, given only because they thought they would be in trouble with the Government if they refused.

On the other hand, on the west coast of Bougainville in 1962 two schemes were started by the native people on a purely voluntary basis. In both cases, irregularly shaped plots within lineage holdings were given to individuals. In one the tenure of these blocks was converted to freehold under the Land Tenure Conversion Ordinance, in the other they remained governed by custom. Both these projects have been successful, with about a quarter of a million each of coconut palms and cacao trees planted. One of the reasons for their success is that 
roads to coastal landing places were built before the bush was cleared, so that the people knew that they would be able to get their produce out if they grew and processed it. The Marist Mission did much of this road work, or provided equipment for it.

Roads are prerequisites to any successful attempt to get people to work on developmental schemes. After a road was built around Buka Island in 1963 there was a great increase in planting. In contrast, a projected scheme on Manus Island languished for years because no road was built. The official thinking in this case seemed to be that there had to be an existing economic production in the area to justify the making of a road. This attitude can only lead to delay in development.

There is still a great deal of arable land left in most parts of Papua New Guinea which could be developed if road and marketing facilities were extended. The problem is to design development schemes which will be supported by the people. It may, for instance, be more promising to break up land acquired for resettlement purposes into larger areas, defined by natural boundaries, for specific lineages which are short of land, instead of dividing them into little square blocks for individuals, and to treat them as native land governed by custom rather than to convert them to freehold. Groups of lineage members could alternate in working these 'extensions of lineage lands' for cash cropping and the whole lineage would benefit. A scheme of this kind would have a very good chance of success if the resettlement area were fairly close to and readily accessible from the lineage's traditional settlements. But even if this is not possible, this scheme would still combine the advantages of the usual individual smallholder schemes with the additional ones that many members of the same lineage can have contiguous plantations, that familiar work patterns can be used, and that the settlers can identify with the land as a group, which would overcome their isolation and give them a far greater psychological and practical security.

The main disadvantage would be that the plots would be irregularly shaped, but this does not greatly matter if by using such blocks an acceleration of economic growth is achieved. Land boundaries can be straightened later, if required-in Papua New Guinea with its rugged terrain and the use of natural features such as watercourses and ridges as boundaries, it may not be necessary; in fact, the traditional 
boundaries may prove to be superior to any straight lines drawn by trained surveyors, which brings us to the objections raised to the use of traditional forms of land tenure.

Objections ate often based on technical grounds, for instance by surveyors who think in terms of access roads, evenly shaped blocks, and so on; or by agricultural officers who have adopted these prejudices and supplement them with their own regarding the ease of inspection of plantations and of pest control by having them all grouped together; or by bankers who believe that only land which has been surveyed and title to which is guaranteed by European law offers sufficient security for a loan. I will not discuss the strength of these objections, although at least some of them have obvious merits, since none of them, however strong, should be allowed to dominate decisions regarding the future land tenure system of this country, simply because a technically ideal system is useless if it is not acceptable to the people. There are, however, other kinds of objections which deserve greater attention.

Possibly the most serious protest offered is that the use of traditional institutions would 'crystallise' or perpetuate them, and with them, tribalism, and thus jeopardise the entire future of this country. But this is unlikely. Indeed it is more probable that there will be an opposite effect. Tribalism flourishes among people with low incomes and little diversity of occupation. If the rate of economic development in rural areas can be increased by the use of traditional institutions (and this is far more likely than if they were replaced by imposed alien institutions), there will also be a tendency for persons from many different ethnic groups to go to towns or othet central places to take up a diversity of occupations--and it is in these multitribal urban centres where ideas of national unity have the best chance of developing. This is already happening under the existing conditions in Papua New Guinea.

The change to cash production in rural areas may not encourage people to return from the towns. Experience elsewhere suggests that the reverse is often true-higher commercial production in rural areas is frequently associated with declining rural populations (Ward 1969: 9-15). 
Moreover, traditional institutions in themselves may well be the only unifying force powerful enough to overcome the dangers of tribalism. The most important practical difference between the two parts of the land law of Papua New Guinea - the law introduced by Europeans and the customs of the indigenous people-it is often said, is the fact that the former is uniform throughout the country whereas the latter differs from place to place. Since a uniform law is surely needed, the argument continues, it is clearly impossible to use traditional institutions, because there are hundreds of different traditional institutions in different parts of the country. This argument is persuasive, but the assumption on which it is built does not in fact exist.

Customary land tenure systems could be incorporated in the introduced law so as to enable dealings in customarily held land to take place in a uniform way throughout the country. This would avoid the disruption of native life which a complete break from customary tenure would cause. There is no need to do away with customary systems of tenure, either for economic or for legal purposes. The differences between the land tenure systems of the hundreds of ethnic groups in Papua New Guinea are only of minor importance. They are mainly matters of detail. The similarities in the systems are far greater than the dissimilarities. Each land tenure system is essentially very much like the other.

It may be objected that this cannot be so because the 'kinship and inheritance' systems of some of the peoples of Papua New Guinea are organised along matrilineal lines and those of others along patrilineal lines. But this does not mean that the methods of inheriting land rights in patrilineal societies are different from those in matrilineal societies. It only means that there are different methods of acquiring membership in a lineage. In both these types of societies the lineage (and not its individual members) is the effective owner of the land. Its members have land rights because they are part of this lineage and it makes little difference whether membership has been acquired because the individual's father or mother belonged to it. The land belongs to the lineage, which can exclude people from or admit them to its land.

Neither in patrilineal nor in matrilineal societies does 'inheritance' therefore mean that land passes from one person or one group to another. The lineage owns the land much as a corporate body does. 
Individuals join a corporate body or are born into the lineage; they leave the corporate body in a number of ways or leave the lineage by death, but their coming and going does not affect the corporate body or the lineage as far as the ownership of its land is concernedexcept that during the time of their membership they have a share in it. The lineage resembles a joint tenancy in that there is a right of survivorship. When someone dies the survivors are the owners, and they are joined from time to time by those who are born into the lineage. In fact the lineage members regard their dead as still having an interest. They are usually buried on their lineage land, and their spirits are concerned about the use and fate of it. People also consider that they are somewhat in the position of trustees for those yet to be born into their lineage.

The local variations mainly relate to what are frequently called secondary rights to land, which are in any case better regarded as contractual rights rather than as possessory or proprietary rightswhich the primary rights attached to membership of a lineage certainly are. ${ }^{1}$ For example, the primary rights of a man in a matrilineal society are to the land of his mother's lineage, but he may also have secondary rights to that of his father's lineage because of cettain (not unusual) events having taken place. If the latter were denied him, possibly the most appropriate way to give him a remedy at law would be to treat him as having contractual rights against his father's lineage because of these events and to make these rights enforceable in the local court. His only remedy now is to claim possessory or proprietary rights in land, which of ten leads to lengthy litigation about a minor matter.

This raises a second issue which is often used as an objection against the continuation of traditional institutions. It is claimed that there are many disputes about the rights to lineage lands which would only disappear if the tenure of these lands were converted into individual, European-type titles. It is true that there is a great deal of litigation at present, but the reasons for this situation are complex and it is

1 Trees and crops are customarily regarded as property of the planter and not as parts of the land. They were also, at least in the days of subsistence agriculture, treated as the personal property of individuals rather than groups. 
unlikely that it would dramatically improve if the traditional system of land tenure were legally abolished.

One important reason for the frequency of litigation is that there is at present no need for anyone to hesitate to claim land, as it costs nothing to have a case heard at first instance and to appeal it through higher courts. Even if one's claim has little merit it could, with luck, succeed. Legislation to empower courts to award costs against an unsuccessful plaintiff, should it appear from the evidence that the claim was vexatious or of little merit, and the fixing of fees for appeals might stop many people from beginning and pursuing doubtful actions.

Another reason for litigation, and one which is indeed closely connected with traditional ideas, is that most native people feel that they have a bona fide claim to all land on which their ancestors have dwelt (particularly if some of them were buried on it), whoever may have lived upon and used it later. Because the pattern of native life was, and still is in places, one of much movement, caused by the system of shifting agriculture, by raids of enemies, and by the belief that it was necessary to leave any place where there had been much illness or some deaths, different lineages have often successfully occupied an area of land. Each of these lineages (or clans), if still in existence, now believes that it has a good claim to this land, no matter who occupies it at present.

To avoid multiple claims to the same land because of this belief, it will have to be made known to the people that only proof of fairly recent occupation will establish a good customary title. The law must 'fix upon a definite date since which the plaintiff's cause of action must have arisen'. The situation in Papua New Guinea is similar to that existing in England in the Middle Ages when people sought to prove title by alluding to transactions in the land in much earlier times. It became necessary by successive acts of Parliament to set the limits of legal memory so as to prevent too much delving into the doubtful past. The last of these dates, for purposes of actions on Writs of Entry as a means of trying title to land, was the year 1189 , set in 1275 by the Statute of Westminster.

Presumably this date eight hundred years ago, is, under existing law, also the limit of legal memory concerning events in customary land 
matters in Papua New Guinea. ${ }^{2}$ The Land Titles Commission, however, usually uses the date of the assumption of sovereignty by Australia or Germany, or the date of effective administrative control over an area, as the time which it does not look beyond. But this is a 'rule of thumb' and has not had the approval of a higher court or of the legislature. The setting down, and the making known to the people, of some such limit is very necessary.

There are many causes for disputes, but the main type of dispute which the use of traditional institutions would help to stop is that which arises when the amount of accessible land is not sufficient for the amount of cash-cropping being undertaken. Disputes of this kind occur within the lineage when individual members use more than their share of lineage land for such crops. If cash-cropping were encouraged not as an individual but a group enterprise, many of these disputes would not arise. Disputes also occur when one lineage encroaches on the land of another. But the setting aside of lineage areas distant from the village and gardening areas for cash-cropping would eliminate many of these disputes. As indicated before, these disputes usually arise not because there is an overall shortage of arable land but because everyone tries to plant in readily accessible areas. The building of roads, negotiable by tractor and trailer, to areas selected for cash-cropping by the lineages, before these areas are planted, is a prerequisite for success. This would be a more promising course of action than waiting instead for a legal miracle while blaming traditional institutions for ills which can only be cured by land reforms (as opposed to land tenure reforms) and by providing better road and marketing facilities.

Even the imposition of ideal new European-type land laws will not bring about such miracles, mainly because they are designed to regulate merely the rights to land whereas the traditional institutions they want to replace are part of a system involving every aspect of native life. This means in practice that these new laws, applied to native land, do not affect rights to land alone. Any transaction or decision also influences the social, religious, and other aspects of the lives of every

2 It is not the decisive date according to which relevant custom itself has to be determined. Under the Native Custom (Recognition) Ordinance 1963 the relevant custom is the custom at the time when a particular issue arises. 
member of the land-owning lineage as well as lineages closely associated with it.

Under these circumstances, the use of traditional institutions is not merely better politics but a matter of sheer necessity. Politicians and experts, working together in the shaping of policy, must try to learn from the ordinary village people how to use existing institutions, how to modify them where necessary, or how to develop new institutions in a way which will appear familiar and understandable to the people and will therefore be acceptable to them. 


\title{
I3 Cash-cropping and population pressure
}

\author{
T. M. Kambipi
}

Before the white missionaries and the Government came, we people of Papua New Guinea lived in tribal groups. Law and order and affairs of social life of a group were governed by the chiefs and elders of the tribe independently of the other tribes surrounding it.

Most of the land which is claimed today was claimed when the first settlers entered an area. This is the case in most parts of the Highlands and, I believe, in the whole of Papua New Guinea. In my area, when the first settler went on to a particular piece of land, he claimed a large area, hundreds of acres, and this land now belongs to his tribe. The same applies to all other tribes around the country, although each tribe has its own story to tell. This story goes from father to son, from one generation to the next. If the first settler was a powerful man he claimed a lot of wonderful land, but if he was weak and afraid of his neighbours, he did not get much land for himself. Sometimes, now, we have trouble with the big clans and the small clans in the Highlands. When the clan of a weak first settler grows bigger, it has no longer enough land for gardens and house sites. But when the first settler was powerful, even when the population has grown, the people still have plenty of space to make their gardens and to move around on their own land.

In the olden days, when a clan did not have enough land for its people, the leaders went to see a neighbouring tribe and asked for a few blocks of land and talked about the pigs and goldlip shells they would have to pay to the owners of the land. When the land-owning clan agreed, the sale was made. The two tribes came together and made boundaries by marking rivers and valleys or by planting bamboo as a sign of their agreement.

There were other reasons for acquiring land. At the times of tribal fighting, a tribe whose men had killed one or several men of the enemy tribe had to pay for these lives either with pigs or by handing 
over a few blocks of land. Very often these two tribes would come to an agreement and from then on they would live in peace. But sometimes, when one clan was much more powerful than the others, it overran many of the smaller tribes and came thus in control of much land. Even then, however, one of the neighbouring clans would usually act as mediator. It had to be on good terms with both fighting clans, but in particular with the victors. It would intervene on behalf of the defeated clan, discuss the terms of a peaceful settlement with the victors, and try to persuade them to give back at least some of the conquered land. Especially if the victorious clan had killed a number of men, it was not right according to our culture that it should keep any of the conquered land. If the weaker clan had simply been chased off its land without anyone being killed, most of the conquered land would still go back to the defeated clan, but the victorious clan would keep some of it. While negotiating with the victors, the mediating clan would help the scattered defeated group and, if successful, would lead it back to its own place. If the victors refused to give back the conquered land, there could be no peace, the fighting would continue.

Today land disputes are a serious problem in the Highlands and some of them lead to bitter fighting in which people are killed. These are mainly land disputes about ownership and boundaries between hostile clans. But there are also disputes between friendly clans and even within clans which make the people cross and angry.

There are two major factors which cause the land disputes and the fighting: the population increase and the fact that the Highlanders are keen businessmen. In former times many people died because of lack of medical care and hygiene. When white missionaries and the Australian Government entered this area, they brought doctors, medicine, and health education. Therefore the clans all over Papua New Guinea have increased by up to 70 per cent in population compared with the times before the influence of Europeans. The villages in the Highlands are thus extremely overpopulated. For this reason the clans do not own sufficient land for the younger generation to live on. Hence the smaller clans try to win back the land which was taken from them by more powerful clans at the times of tribal fighting, and for the same reason the bigger clans are trying to gain more land for their people. Moreover, the members of both, the small and the big clans, are keen 
businessmen. The people in many villages have started some kind of business to make a new way of life. They grow more crops and plant coffee trees so as to earn more money, which means that they need more land and there is a great shortage of land for economic development.

As the population grows and the sense for business develops, more and more disputes over boundary lines and ownership arise. The most serious are probably those caused by attempts of clans to regain the possession of land they have lost by conquest in the times of tribal fighting. But there are also disputes over land which has been sold to other clans for pigs or pearl shells or which has been transferred as a compensation payment for the killing of one or two men from another tribe.

In our days land which has been acquired in this way is disputed too, because the tribe which lost it now considers that it did not make a good deal. It believes that the land would now offer good business opportunities, by planting it with coffee, putting a trade store on it, or starting a cattle farm. These are strong reasons for trying to obtain a few acres of land. This way of thinking is with everybody, with every tribe in Papua New Guinea, mainly because some members of the younger generation believe that the payment which the tribe received, such as pigs or shells and the like, is not enough. They consider the tribe should go to court and if they get the land back it will be all the better. The young men are always telling the ordinary village people to be strong and to insist on taking the land back. These are the problems which come up about land which has been purchased. This is another type of land dispute in the Highlands.

It also becomes increasingly common that two groups go to court because they disagree about who owns the land traditionally, even though there is a true story about the history of the land: either it was claimed by the first settler, or it was acquired by agreement or it was obtained by force. Now that the people of Papua New Guinea see that if you are clever and know how to go to court about land matters and put forward good arguments which the court will listen to, you may well be able to win back land for your group. This kind of idea is becoming widespread in Papua New Guinea now. As I have said, there is a true story about how the land was first acquired, whether 
by force or by other means, but a lot of people when giving evidence to the Land Demarcation Committee or the Land Titles Commission or in court tell all sorts of lies. Half of the evidence given during these hearings is just lies; only about 10 per cent is the full truth.

Finally, I would like to talk about disputes over so-called 'no-man's' lands. First of all I want to point out that we do not have any real no-man's land in the Highlands. Even if land is about forty or fifty miles away from the village, it still belongs to a particular group, for cutting timber or feeding the pigs and so on. As I have said, even if the land is forty to fifty miles away, it still belongs to somebody, and the story of the history of the land which has been passed on through many generations is still alive. It tells of who owns the land, of who was the frst settler, and how he walked over the new land. There is, however, a type of land which is a bit similar to no-man's land.

Before the Europeans came, our people lived mostly in the hills and mountains, not on flat land. They did this because they were frightened of their neighbours. They found it safer to live on ridges and to feed the pigs in the valleys and on the flat land. Whenever there was disagreement between two tribes for some reason or other, the fight took place in the valley or on flat land near a river. These places where no one used to live and which were not used for farming and gardening were called 'fighting places'. Strong men of the neighbouring tribes usually went hunting on these 'fighting places', but cowards would never go there; they went to the peaceful hunting grounds of their own tribe. Nowadays these 'fighting places' are being claimed by many clans. A lot of disputes are arising because of these 'fighting places'.

How can the problems caused by these land disputes be solved?

During the last years the Land Demarcation Committees have frequently decided such disputes, but I have found that many of these Committees do not carry out their work in a fair manner and that there is much bribery. It would be very helpful in solving our land problems, if the Government could find some way of settling these disputes in the traditional way, by mediators who intervene on behalf of the weaker group, as it is done in our own culture. But until then, I feel, the disputes must be decided by a court, the Land Titles Commission or another court, after hearings of one or two weeks.

During this time the Land Titles Commissioner should obtain as 
much information as possible from the village elders and from other witnesses of the clans. He should also hear the advice of pioneer missionaries, church leaders, and kiaps (field officers of the Administration) and others who usually know about the history of the dispute. But the final decision should be made by the Land Titles Commissioner alone, and I think the people will accept his decision.

And his decision should be final. 'Appeal' is a new idea, a new word for people like my people in the Highlands. When people say 'appeal' they have a different picture altogether and do not understand it. 'Appeal' to them means that they must bring hundreds of dollars to a solicitor, and if they bring more than the solicitor requested, it will help to win the land back because he will be pleased to receive so much money. For instance, if the solicitor asks for $\$ 200$ for his work, the group which wants the land back by an appeal will give him $\$ 400$ instead of the requested amount. This kind of idea is in the minds of people who lost land as the result of a decision by the Land Titles Commission. This idea began to develop when the kiaps entered our area and acted as magistrates in court. No payment was requested by the kiaps, nor later by the Land Titles Commission. As a result of this, the people think that when they pay money to a solicitor or judge it will bring back the land which they lost because of the decision by the Land Titles Commission. In a Western legal system, if you are dissatisfied with the judgment, you take the case to the Supreme Court and from there to the High Court. This is the Western way, but in a country such as Papua New Guinea, we have to adapt the system to the particular circumstances of the country and its people. If the law were changed so that the final decison would lie with the Land Titles Commission, I would be very happy, because it would keep the people from spending money unnecessarily by lodging an appeal through a solicitor and it would also rid the people of their wrong ideas about an 'appeal'.

In the Highlands, and probably in the whole of Papua New Guinea, whenever there is a dispute between two tribes over land, they usually recall the history of this land for the past five or six generations, and any tribe that can give the history of the land it is claiming for this period is probably telling the truth about the basis of the claim. These stories of the past have been passed down through the generations from 
father to son. For this reason it is important that the Land Titles Commission should hear evidence going back five or six generations, about how the ancestors took over the land. Each piece of land in the Highlands has its one true story and it must be established before any decision regarding the land can be made which is acceptable to the people.

Regarding the decision of the Land Titles Commission, I think two types of cases must be distinguished: first, cases where the true history of the land shows that the present occupants have acquired it by peaceful means, that is by settlement, by purchase, or as a compensation payment; and second, cases where it shows that the land has been acquired by force. In the first case, the Land Titles Commission should make a legal decision. This applies especially in cases where land has been purchased from another tribe and the group which sold this land tries to win it back through court action. In this kind of dispute the Commissioner should be very careful not to disturb the traditional land agreements. If they are put in question, I am sure there will be fighting and killing and the disputes will grow beyond the Government's control. I believe it is a good and healthy way in our culture to purchase land from a neighbouring tribe or to receive land as a compensation payment. The group which owns the land now is owning it rightly, because the land was not taken by force but was acquired by a peaceful agreement. These traditional agreements must be accepted and there is no room for any compromise.

This is different when the Land Titles Commissioner finds that the land has been taken by force, by conquering another tribe. As I said earlier, it is not right according to our own culture to take the land of a defeated tribe, especially if one or several of its men have been killed. But in the past some groups have kept at least part of the Iand they conquered and a peace settlement was usually the result of mediation involving give and take on both sides. I think in these cases the Land Titles Commissioner should therefore also work out a compromise.

Sometimes he may be right to tell the conquerors to return all the land. But I have seen in the Highlands that much of the land powerful groups have conquered in the past has been developed. When the population increased the tribe began to expand into the conquered 
areas, building houses and planting coffee. If the Commissioner decides, for instance, that this land must go back to its original owners, it will be very hard for them to pay for all the improvements; it may involve thousands of dollars and hundreds of pigs as compensation. It may also cause new trouble. The group which has been cultivating the land for ten, twenty, or even thirty years, feels frustrated about having to return the land and fighting arises out of such decisions. I have seen these things happening in New Guinea.

In these cases the Commissioner may be right to tell the conquerors to pay compensation, either in money or pigs, to the original owners of the land, or to return only the unused land, or to divide the land between them and the original owners. I do not think that the Commissioner should say that the conquerors could keep all the land if they have conquered it before the first kiap came and that they have to return it all if it happened afterwards. I believe it is better that in all these cases a peaceful settlement is reached. The Commissioner should talk with both groups about the great trouble which could arise if he were to order the return of all or none of the land. He should talk about compensation for improvements and for conquered land, which is not to be returned, and about dividing the land. If the land is divided, the boundary should be marked in a traditional way. It should follow a river or a creek or bamboo should be planted. This would help the people to understand that these boundaries have to be respected.

I am sure that the people will try to respect the decisions made by the Land Titles Commission to settle their land disputes. But I am not sure that even the best decisions will be sufficient to solve the problem which, as I said earlier, is due to the shortage of land caused by an increase in population and by the people's interest in economic development. The Land Titles Commission and the Government have to work together. If there are many land disputes in a certain area, it must be investigated whether the population has grown too big for the land it is occupying. If the people in a certain area are really short of land, the Government has the right to move some of these people to areas where there is a surplus of land and settle them there. This is a good solution. Nowadays I can see that a lot of people from the Chimbu and Watagenga clans have settled in other areas of Papua New Guinea. They live in Port Moresby, Lae, Rabaul, and other areas. Enga, 
Watagenga and Chimbu are quite happy to leave because at home they have run out of land and their areas are overcrowded. Not far from Hagen the Government has set an example. In the Wahgi Valley it has divided land into blocks and given them to the Watagenga to settle there. I think this is a good idea. The people from Wabag who are so crowded in their area are moving now, family by family, to this new settlement. Now this idea is in the minds of people who are short of land. In my particular area, Baiyer Kompiam, we do not have enough land now, and there are the same problems in other areas. There are land disputes in my area because of the people being business-minded or because the tribes are increasing in numbers and want to take over more land. I think that within the next ten years even some of my people will have to be resettled somewhere else. By that time some parts of the Highlands, especially the Western and Southern Highlands and the Chimbu District, will be heavily overpopulated. The population is growing fast and the Government should prepare now for the future.

When I was about seven or eight years of age, the first Europeans came into my village. They were a missionary and his wife. From then on I grew up experiencing life in the two worlds. This means I have experienced the cultures of the old and new ways of life. I am a person of two worlds.

I have written the facts down which I have mainly seen, known and experienced. 


\section{I4 Law enforcement or land reforms}

$$
\text { J. Nilles }
$$

When I arrived in the Chimbu area at the beginning of 1937, the indigenous population had not yet taken much notice of the proclaimed pax Australiana. There was one government officer, stationed at Kundiawa together with about fifteen indigenous police constables, who occasionally patrolled the area, which at that time was still classified as uncontrolled. The other Europeans were limited to their three mission stations and had contacts only with people living nearby.

Traditionally, the Chimbu are subsistence farmers, but with the arrival of Europeans began an increasing demand for fresh food and pigs which the people could exchange at the government and mission stations for the much appreciated shells and iron tools. To do this a man had to make larger gardens, grow more food, and raise more pigs than was necessary for him in former times to meet his family and clan obligations. Since European contact, and especially with the introduction of European vegetables and coffee, there has been a change from subsistence farming to market gardening and cash-cropping. This change, together with the purchase of land by Europeans, has resulted in an increasing land consciousness amongst the Chimbu. But like agricultural people all over the world, the Chimbu have always felt a deep emotional attachment to the land which they inherited from their ancestors and on which they live together with their ancestral spirits as one perpetual community. A man without land has no home, no name, no security, and no status.

The Chimbu are politically and socially divided into exogamous clans (which are further subdivided). The borders of the areas claimed by the various clans are not precisely defined, but are usually generally known by natural landmarks such as watercourses, rocks and groves (they tend to be vaguest in forest areas). Between the borders of clan land and on either side of them there was often a portion of land known as 'fighting' or 'no-man's' land. Occasionally a daring man would fence and cultivate a plot and thereby claim ownership, but 
usually it was left for pig grazing. There were also areas of open grassland, swamps, and groves to which no clear claims were made, partly because they were economically useless and partly because they were feared as dwelling-places of hostile spirits (for instance malariainfested areas along the Wahgi River). When later payment was offered by Europeans for such land, the leaders of the clans living nearby had to put their heads together to reach an agreement as to who should accept payment and how much each should get.

Although the borders of clan land as well as the boundaries of individual plots within it were usually known and accepted, they hardly had a permanent and absolute legal status. The boundaries had to be carefully watched, to prevent another man or another clan from encroaching upon the land and claiming it. A clan member would try to encroach upon clan land left for grazing pigs and make a garden and build a house without consulting his clan leaders, and the clan leaders would attempt to expand the borders of their clan's land, since this was also a means of extending their power and prestige.

Yet, despite the fact that land was already so short in some areas that Chimbu had begun to migrate for this reason into the Asaro Valley and across the Bismarck Ranges, the Chimbu probably never started a war against each other or against their neighbours in order to obtain more land. On the other hand, wars frequently resulted in groups being driven off their land and their enemies encroaching upon it. Thus it was not uncommon that land passed from the control of weaker into that of stronger groups. Although the Chimbu did not set out to conquer land, conquest was in fact an important traditional means of redistributing land according to the laws of supply and demand.

Looking at the ways in which the Chimbu traditionally dealt with their land disputes, we must first of all distinguish disputes within the clan and disputes between different clans.

Intra-clan land disputes were and still are by no means rare. Bickerings and quarrels over encroachments and infringements of all kinds between individuals and sub-groups or between individual group members and their leaders were and are on the daily order of social events. But they rarely led to open hostilities and could be settled by compensation payments. 
In the case of inter-clan disputes the outcome depended on the past relationships between the clans involved. The Siambugla clan, for instance, lived next to the Waugla clan in a state of friendly alliance. Land disputes betwen these clans could develop into a fight, but before any serious bloodshed the leaders of both sides would start negotiations for a peaceful settlement, involving the payment of pigs, shells, or other valuables. In the case of traditionally hostile groups, however, war was the only answer. This meant that there could be no permanent settlement, since the defeated clan would not accept its defeat but only wait until it was strong enough to renew the war.

Since these hostile clans have silently accepted the pax Australiana forced upon them by the Government, this traditional way of dealing with land disputes could be no longer applied. Consequently a number of such disputes are still hanging in the air and up to date no Land Titles Commissioner or Supreme Court judge has taken sufficient care to settle them.

At about the time of first contact, the Kammaneku clan, together with the Naruku clan, had, for instance, driven the weaker Endugla clan from formerly occupied land, which the latter still claims as its own. Because the area in question was near the new government station in Kundiawa, the Endugla did not dare to sharpen their spears and arrows. But the cold war is still going on. Under the protection of the Government, the Kammaneku have built pig festival houses on the conquered land and have even opened a burial ground for their dead to which the Endugla strongly objected and to which, in former times, they would have immediately responded with war.

These are the kind of cases which, together with the question of defining precise boundaries between the land of hostile clans, especially in areas of no-man's land, cause the most serious land disputes in the Highlands today, simply because there are no established traditional means of dealing with such disputes in a peaceful way. This view is confirmed by the fact that the traditional mediation procedures still work satisfactorily in the case of land disputes within the clan or between friendly clans. Disputes of this kind very rarely come to the notice of government officials.

The old leaders are not yet fully convinced that any modern alternative to the traditional rule of war between hostile clans is really work. 
able. Whenever a government officer comes to a place to investigate a land dispute, the leaders will try to impress everybody by staging a great show of manpower, and their speeches are mainly boisterous recordings of their past and present superiority over their weaker enemies. But the younger generation begins to see and to understand the unreasonableness of the law of the jungle and is ready for just arbitration.

It must be admitted, however, that the doubts of the old leaders are not merely a result of their reluctance to change: just arbitration of disputes cannot take over the function of war as a means of redistributing land according to actual needs. To solve the problem in its entireness the Government will have to find a way which allows the Chimbu to expand peacefully into less densely populated areas. Since the creation of the District Advisory Council, its native members have at nearly all meetings asked the Government to open those parts of the Karamui-Bomai and Ramu where a surplus of land exists. The Government has not followed this suggestion. It has, however, opened an oil palm project on New Britain and a tea growing project near Mt Hagen, and a number of extended families from the lower Chimbu have taken part in them. But that goes beyond the scope of this paper.

How can a peaceful and lasting solution for the land disputes in the Chimbu area be found? On the one hand, I am sure that the greatest possible use should be made of traditional mediation procedures, on the other hand I doubt that much will be achieved if each individual case is looked at separately and an attempt is made to settle it by a political compromise. It will be necessary to have a judicial body which can decide disputes on the basis of simple general and objective legal criteria, at least if one of the parties involved in a dispute so desires.

I feel it would be even better to use this body to settle the question of clan land boundaries for the entire Chimbu District once and for all, whether or not they are at present disputed. This approach is also necessary if the Government is to introduce a land tax for the sake of internal revenue and in order to ensure that the best possible use is made of all potentially arable land. I know that this would be a very unpopular decision, but it is one which the Government has to face up 
to in the near future. Further, only after all the clan land boundaries have been ascertained will it be possible to assess the land needs of the various clans and to prepare the ground for a realistic resettlement program or even a general land reform. But since these questions are probably more urgent for the Chimbu District than for other parts of Papua New Guinea and since at least the dispute settlement procedures should be the same throughout the country, I will now concentrate on this specific point.

In my view it is necessary to set up a judicial Land Adjudication Commission for each District. The Chairman of this Commission should be a trained lawyer and high priority should be given to filling these posts as quickly as possible with indigenous graduates. The Chairman should hear disputes together with two indigenous Assessors who should have secondary education. They should not only advise the Chairman but together with him work out the decision to be pronounced by the Commission. Groups involved in a dispute should each select a committee of about six members, one being the speaker, as representatives. (I feel that Local Government Councillors should not become members of these committees because the Council should remain above such disputes.)

The Chairman and the Assessors should first of all try to help the parties to work out a settlement among themselves which is acceptable to both sides. If such a settlement is reached it should be accepted. But the Commission should not merely record it in writing. First, the boundaries of the land in question should be marked by the parties in the presence of at least one of the Assessors. (The concrete markers used by the Lands Department in recent years would be suitable.) Second, a reasonably accurate map of the land showing the position of the boundary marks should be drawn and then signed by each of the representatives of the parties as a proof of their acceptance. Third, a meeting between the two parties should be arranged. Each should bring along one or two pigs and also vegetables to the place of the meeting. The pigs should be killed and cooked together with the vegetables and presented by one party to the other. During the presentation the usual speeches should be given. The Chairman of the Commission and also a representative of the Administration should be present at 
the meeting and one of them should emphasise the importance of the day in a few words. It is also important that after this meeting any person who trespasses on the land will be energetically prosecuted to prevent the building up of new tensions.

If a voluntary settlement proves impossible, the legal authority of the Commission has to come into action. I think the Commission will again and again be asked to decide the following two issues: first, who owns land which has been obtained in the past by conquest, and second, who owns land which until recently has been no-man's land. For both cases clear and simple answers should be given. In the latter, I think, the only workable solution is to divide the land equally between the groups bordering the area in question. The first case involves more difficult points and it is probably impossible to come to any decision unless we regard occupation at the time of first contact as decisivewhich would mean the year 1933, at least for the Chimbu area, when J. Taylor, the first government officer, together with the two Leahy brothers, contacted the people coming from Goroka and as far as the Hagen area. This solution is practicable because from all clans in the Chimbu District influential men are still alive who know the borders of clan land as they existed at that time. It is also acceptable to the people. A number of leading men all over the Chimbu District have told me that this date could be taken as a basis, but that the Government would have to make the decision.

And what are the alternatives? A Highland Member of the House brought up the matter in a private member grievances debate in 1971 . He claimed the right of the stronger even after contact and declared decisions made by Land Titles Commissioners during the last years were not acceptable to his people. The other Members did not agree with him because his statement was influenced by personal motives, and it would indeed be absurd to uphold a claim to land based on conquest after first contact at a time when the use of violence in land disputes is a serious threat. On the other hand, before first contact, force was at least in fact an important means of establishing clan borders. Moreover it is just not feasible to unravel, let aione to undo, the history of conquests in the Highlands. There has to be a cut-off point somewhere, and the date of first contact is by far the most convincing. 
This rule like any other will cause some hardship and there is certainly room for traditional compensation payments. But it must be remembered that the aim of deciding land disputes is justice and not the equitable distribution of land. To settle land disputes is one thing, to carry out land reforms another, although both problems have to be tackled if either of them is to be solved. 


\section{Is 'They fight for fun'}

\section{B. Orken}

When I was leaving Port Moresby in May 1959 to take up my appointment as Native Land Commissioner in the Eastern Highlands, the then Chief Commissioner, the famous Ivan Champion, said to me in his quiet way "There are a lot of disputes over land up there and the people sometimes get quite angry over them'. I had known, and worked with, Ivan Champion for many years and I was fully aware of his calm and undramatic ways, but surely what he said to me must have been the understatement of that year, because I soon realised that there were literally thousands of disputes over land and that the parties to these disputes not only 'sometimes got angry' but they more often than not engaged in pitched battles resulting in deaths, serious injury, destruction of property, and much social unrest, inhibiting the peaceful and orderly development of the area.

Why is it that the Highlands of Papua New Guinea have become notorious for the frequency and the virulence of their land disputes? In this personal narrative I shall attempt to analyse this situation, in the light of my thirteen years' experience of the people and the area in which they live. I shall also discuss some of the several attempts which have been made by the Legislature to provide a legal framework within which disputes over land can be resolved with consequent benefit to the economic, social, and political progress of the people.

I suppose the quick answer to the question of why people in the Highlands fight with such frequency and ferocity over disputed land would be that there must be a grave shortage of arable land, and this factor plus the spectacular population growth over the past twenty years or so has produced tensions and rivalries which culminate in bloody and serious breaches of the peace.

These conditions are certainly present in such areas as most of the Chimbu District and in the Wabag Subdistrict in the Western Highlands, and undoubtedly they contribute a lot to the land dispute problem. But there are two other circumstances which, whilst they have been known for many years, do not appear to have the attention 
focused upon them which their importance justifies: the inherent physical aggressiveness of the people and the growing realisation that land is an economic asset.

I believe that there is a marked cultural emphasis, in all Highlands groups, on physical aggression. In pre-contact years, and for many years thereafter-if indeed it has ever ceased-inter-tribal warfare was the most constant and popular social activity. An early kiap in the Chimbu area, the late Leigh Vial, used to say that 'they fight for fun', and in the light of the history of these people over the years, that was not the superficial judgment it might at first glance appear to have been.

They find their 'fun' in fighting because physical aggression is the 'warp of the cultural pattern', as K. E. Read has pointed out (1954: 866).

Both men and women are volatile, prone to quarrelling and quick to take offence at a suspected slight or injury. They are jealous of their reputations, and an undercurrent of tension, even latent animosity, accompanies many interpersonal relationships. Dominance and submission, rivalry and coercion are constantly recurring themes and there is an unmistakeable aggressive tone to life. The majority of social rewards go to the physically strong and self assertive, to the proud and the flamboyant, to the extroverted ex-warrior and orator who demands, and usually obtains, the submission of his fellows. As a result we find that people are markedly aware of themselves as individuals and the majority of social situations reveal a high degree of ego involvement.

In all my dealings with the people in the hearing of land disputes I am constantly coming across individuals with all the characteristics enumerated above.

These then are some of the people who were presumably in the minds of the legislative draftsmen when they were writing the preamble to the Land Titles Commission Ordinance 1963. It is sad to have to write that hopes of expeditious and final determination of disputes as to rights in land' are as far off as ever; and that the 'universal recognition' given to 'judicial authorities independent of control by the Government of the day, doing justice to all parties in accordance with the law' is seldom extended in the Highlands where, very often, the 
unsuccessful parties to a land dispute threaten the Commissioner with violence and where during the actual hearing there is always an air of tension and apprehension of violence. ${ }^{1}$

Despite the fact that 'conquest' and the quest for more favourably situated land was an important element in the incessant tribal wars in the Highlands of the pre-contact period, I am convinced that it was not until the early 1950s (and in some areas of the Southern Highlands until the early 1960s) that land came to be regarded by the people as a source of money, that is as an economic asset rather than a magicoreligious entity in which the concept of ownership rights has been described as 'something enjoyed by the living, in trust for the yet unborn, in order to propitiate the feelings of the dead'.

The stimulus to the change in native attitudes to land came when the idea of indigenous participation in cash-crops such as coffee, market garden vegetables, peanuts, and timber was introduced into the area, notably when Ian Downs was District Commissioner at Goroka in the early 1950 s.

The quarrels and the disputes which attended the early alienation of land were largely, in my opinion, more a matter of maintaining and establishing prestige as the group with whom the Administration was dealing than of issues aroused by the wish to acquire sums of money by the sale of land, although of course there were individuals who right from the start were aware that the sale of land and the presence of European farmers could add to the money income of the people.

It is important to realise that in pre-contact days there was very little permanent settlement on or utilisation of the land situated on the valley floors. Most groups lived a hamlet-like existence on ridges or elevated river flats and the group itself consisted almost invariably of an extended family or patrilineage. John Black, who was Jim Taylor's companion on the Hagen/Sepik patrol of 1938-9 and who was in the Bena area before that date, told me in a personal communication shortly after I came to Goroka in 1959 that "land was not at a premium then [in 1936] as it is today [1959]'. He further stated that 'in my view it is only because of government power that anyone has come down

1 From 1960 to 1971 I was involved on fifteen occasions with acts of violence committed by one or both of the parties concerned. 
from the ridges and the hills to live on the valley floors' and even at this very time there are still very considerable areas of open land which are not occupied in any way, save for the adventurous few who have cautiously infiltrated into the area and made subsistence gardens and a few pig houses there following upon the opening up of roads and patrolling of the area. And should these adventurous people wish, for example, to establish a cattle project, or plant coffee, or start a trade store, then it is certain that members of a rival group will violently dispute their right to do so.

The following example will I hope make clear the point I am trying to make here regarding the increased awareness by the natives of the economic or money value of land over which they claim ownership. In 1949-50 some 911 acres of what is now part of the town of Goroka was purchased from the adjacent Gahuku-Gama groups for $£ 1541$. Jim Taylor was the District Officer at the time of this purchase and all those who know this remarkable man would unhesitatingly agree that he would not have gone ahead with the purchase had there been the slightest reason to believe that any injustice was being done to the native controllers of the land or that they were being paid anything other than a fair price. In 1971 an area of native land of not more than 1 hectare ( $2 \frac{1}{2}$ acres) in extent, in close proximity to the western town boundary, was offered to the Administration for $\$ 13,000$ ! And I know of other slightly irregular dealings by some Europeans with native controllers of other land near the town boundary, where sums of more than $\$ 1500$ per acre have been paid over. ${ }^{2}$

We now have what I consider to be the three main reasons why disputes over land occur with such frequency, and are pursued so bitterly, in the Highlands: first, the growing pressure of increasing population on available arable land, second the natural aggressiveness of the people who but a scant forty years ago (and in some areas only fifteen years ago) found an outlet for their aggressiveness in incessant

2 It is not my purpose here to condemn these arrangements. In my view they transgress the Land Ordinance, but the native parties and the Europeans concerned seem quite happy about the deals which have taken place. And so the natives should be, for if any dispute arises then the European involved could not enforce the agreement he has paid for so dearly. 
tribal fighting, and third an appreciation of the amount of money that can be obtained for the sale, lease, or cash-cropping use of land if ownership rights to it can be established and recognised.

Broadly, the typical dispute over land arises from two main circumstances: an attempt by a group to assert control and ownership rights over portion of the ga'me mikase (lit. 'no-man's land') or buffer land which separated the limits of the territory of rival groups, or an attempt by a group to regain control and ownership rights over land from which they had been driven away in pre-contact days.

The areas of no-man's land were seldom occupied or utilised for any length of time apart from a dominant (for the time being) group burning the kunai grass on it, collecting nuts, and hunting rats, snakes, and small marsupials. Groups on each side of this sort of land have in the past twenty-five years gradually infiltrated into it. The value of these buffer lands has become greater for each disputing group and conflicting claims to control and ownership rights are pressed with increasing bitterness and violence. Each group regards the other as an interloper, neither is prepared to yield an inch, no compromise is acceptable, and both groups advance reasonably good arguments in support of their respective claims to the land.

The sort of evidence one receives during a hearing which attempts to unravel the tangled skein of conflicting claims to no-man's land is concisely expressed in the following lines written by a young kiap who has often assisted me in my work in the Highlands:

'I'd like to ask a question', the Land Commissioner said,

'Who owns this tract of land?'

'It's mine, it's mine, all of it's mine.

My grandfather's blood spilt on that hill,

My mother washed me in that creek,

My brother's buried 'neath that bamboo.

I walked with Taylor here and gave him a pig,

I helped Mick Leahy look for gold.

Old Sergeant Ubom seduced my sister here.

It's mine, it's mine,

All of it's mine--

And the other people are all liars!' 
In Read's view (1953: 9), 'Those who attempt to decide ownership of the buffer lands . . f face an impossible task. They cannot, I feel sure, give a decision which will satisfy everyone concerned.'

The other typical land dispute is concerned with land from which a group was dispersed in the period before effective Administration control was established in the area. In other words, can recognition be given to the acquisition of land by right of conquest, remembering the context of the situation in the Highlands as I have described it? The argument and counter-argument in these cases can be summarised shortly as follows:

\section{Group A:}

We were strong and we defeated and dispersed the other side in the many fights that took place before the Government came. We have controlled and utilised this land ever since that time and we were in control of it when Taylor and other white men came into the area. ${ }^{3}$ We have established gardens on the land, planted trees there and we have houses on it. Our burial and ceremonial grounds are situated there. In recent years we have planted coffee and peanuts on the land and we have disposed of some of it to the Administration and we were the only ones to get paid for it. It is ours, and has been ours ever since the white man came.

\section{Group B:}

It is true that Group $A$ dispersed us from this land before the white man came. But we would have recovered this land if it had not been for the kiaps who came and stopped us from fighting and defeating our enemies. That is our traditional way. The other side have only been on this land since the Administration came. We had been on it for many years before that time. We also have burial

3 J. L. Taylor established the Upper Ramu Patrol Post (now Kainantu) in 1932. In 1933 he and M. J. Leahy led a combined Administration and private enterprise expedition from Bena Bena to Mt Hagen and in 1938-9 he and J. R. Black led a patrol from Mt Hagen to the headwaters of the Sepik River. His name has become a symbol for every white man who first penetrated a Highlands area: I have, for instance, heard it used in connection with the first patrols around Ialibu in the Southern Highlands in 1952-3, some years after Taylor retired from the Administration. 
and ceremonial places on the land and we also planted many of the trees on it.

How does one resolve this sort of dispute? Again, in the overwhelming majority of cases, neither side is prepared to compromise, yield any of their alleged rights, or concede any virtue in the arguments of their opponents.

When I first began hearings in the Highlands and was confronted with the sort of situation described above, I almost invariably found in favour of the group which could prove their occupancy and control over the subject area since the time of effective Administration influence. This was not an arbitrary step on my part. It was settled (if unwritten) Administration policy to act in this way, and from the point of view of the practicabilities of the situation, it is difficult to criticise. Surely, in the name of common sense, a start must be made at some specific time and what better time to select than the time of effective Administration control, i.e. when tribal fighting has been put down, census taken, missions and private enterprise permitted to come into the area and, in general, when pax Australiana was established and recognised?

Yet one must admit that the fixing of tribal boundaries as at the date of effective Administration control can work some hardship on certain groups. It means, in effect, that some groups will have comparatively little land, and of course it does nothing to solve the problem of who should be regarded as having controlling rights over the noman's lands or buffer areas. My only reply to this is that these are particular cases and 'particular cases make for harsh law'. Perhaps, in time, groups which are at present short of land will benefit by resettlement in other areas.

I now turn to a discussion of the several attempts which have been made by the Legislature of Papua New Guinea to introduce a legal framework within which it is hoped disputes over land will be resolved with the minimum of dislocation to the existing social order.

What needs to be stated first is that there seems to be little clear legal definition comprehensible to the native people of what constitutes 'native land', either in the form of statutory provisions or 
judicial pronouncements. It is true that Section $6(1)$ of the Ordinances Interpretation Ordinance 1949-1964 defines native land as

land which is owned or possessed by a native or native community by virtue of rights of a proprietary or possessory kind which belong to that native or native community and arise from and are regulated by native custom.

This is no doubt perfectly explicable to their Honours of the Supreme Court and the legal profession generally. It may well be that the majority of kiaps know what the section means and I hope all Land Commissioners do also, but try to explain (in Pidgin or the vernacular) what is meant by 'rights of a proprietary or possessory kind' to a crowd of angry Wabaga and see how much they comprehend!

The pronouncement of the High Court of Australia, with all respect to the members of that august tribunal, in Geita Sebea's case (Commonwealth Law Reports, 1943, vol. 67: $544 \mathrm{ff}$.) that native 'interests in customary land are no smaller in scope and no less beneficial than the rights of ownership possessed by Europeans owning freehold land' and that native title to land is 'a communal usufructuary occupation with a perpetual right of possession in the community equivalent to full ownership' is of little help to a Land Commissioner trying to resolve land disputes of the nature I have outlined earlier in this paper.

Again, as far as I know, there are no legislative provisions or judicial pronouncements in Papua New Guinea dealing with the acquisition by natives of rights to native land by either conquest or prescription, and as the Land Titles Commission is a judicial body, surely the first question it must decide when hearing a dispute is whether or not, according to the tests enumerated above, any of the groups involved qualify as having legal rights to the disputed land, and indeed, in some cases, whether the land is in fact legally native land at all.

In a hearing by the Commission held at Goroka in 1963 concerning an area of buffer land known as Yahilibiga, the then learned Chief Commissioner (C. P. McCubbery), who presided at the hearing, found that

in this particular matter... there were no interests by way of customary tenure existing in the land at any of the relevant dates, there was no effective occupation at the time of the assumption of 
German Sovereignty, there was none at the time of the first administration patrols and there was none up until the outbreak of World War 2 ... The position in strict law then is that the only permanent interest existing in the land is the basic or radical title of the Administration, as successor to the original sovereign, the Government of German New Guinea. Nevertheless it is clear that the Administration does not desire to press for its full legal rights in the vast majority of cases and is content to allow the Commission to declare native interests even where there is considerable doubt whether such interests exist in strict law.

In the event the learned Chief Commissioner divided the land by delineating a boundary between the territory claimed by the disputing parties which was, in his opinion, based on substantial justice to the parties and in accordance with the rules of natural justice'. It may be added that periodically the boundary has been violated by the respective groups, and there have been numerous brawls and disturbances following these violations. ${ }^{4}$

The Land Titles Commission Ordinance 1963 (and the amendments thereto enacted over the years) has been the subject of much criticism and was due to be repealed by one of the four land bills introduced into the House of Assembly in 1971. But although this bill was the product of much detailed study and imaginative thinking it contains, in my respectful view, nothing which will shatter the rock of native intransigence concerning the settlement of disputes, particularly in the Highlands. With goodwill and legal ingenuity it is certainly possible to draft legislation which is impeccable from the point of view of a community imbued with respect for the rule of law and therefore prepared to accept, all other things being equal, the decision of the tribunal hearing the matter in dispute. But, as I have endeavoured to show in this paper, that is just not the situation in the Highlands of Papua New Guinea. Apart from the vagueness and complexities of the legal issues involved, even if by some magic all these could be cleared away in a manner comprehensible to the people,

4 An appeal against Chief Commissioner McCubbery's decision was lodged in 1964. The Supreme Court has recently remitted the case for rehearing in the Commission. 
I fear that for many years to come it will only be on very rare occasions that the parties to land disputes in these areas will show the qualities of reason and compromise so necessary if a decision acceptable to all is to be brought down.

When this happy state of affaits will come about is anybody's guess. Undoubtedly, spreading education, the realisation that economic growth is being retarded by non-use of good land because of disputes over ownership, the growth of a sense of national unity-all these factors and others will cause a change in the thinking and attitudes of the Highland people to their land. It is too late now for the present Administration to legislate for all land to be regarded ultimately as the property of the state, and at the disposal of the state, but perhaps an indigenous Government of the newly independent Republic of Papua New Guinea will not shrink from this step. Land reforms in this country, including methods to resolve disputes in the Highlands, will be as traumatic an experience to the people concerned as were the Enclosure Acts of the eighteenth century to rural dwellers in England and the collectivisation of agriculture to the Kulaks in Russia in the early years of the Soviet régime. One hopes that totalitarian methods will not be resorted to in Papua New Guinea; nevertheless, if the land problems are to be solved to the ultimate benefit of the country as a whole, all the circumstances preventing this solution must be eliminated as ruthlessly as the situation requires. 


\title{
I6 Politics and societal trauma
}

\author{
W. A. Standish
}

National political factors contribute significantly to the intensity of land disputes during this period of Papua New Guinea's transition from colony to Independent State. The desire of many Highland groups to settle land disputes in their own favour reflects not only the increased land consciousness and intense population pressure, but also results from widespread doubt over the capacity of government institutions to maintain public stability in the near future. Hence while the Australian presence remains, the groups are pushing their claims in the hope of achieving an early settlement, of strengthening their reputation in the interests of a possible later expansion by force (should there be a breakdown of peaceful settlement procedures), or of maintaining their present holdings against challenge. The recent increase in tribal fighting is thus often a result of tensions over land, but specifically heightened by the uncertainty of the political future (see Papua New Guinea 1973).

The special significance of land disputes in times of political insecurity relates to the central position of land in tribal and peasant societies. Land is the source of livelihood and group identity. Its fertility is the strength of the group, and continuing group prestige is necessary to propitiate the ancestral spirits. In March 1973 a sophisticated Mt Hagen student of law told the Commission of Inquiry into Land Matters that, as with every piece of land, an area of his group's land, presently under dispute, contained ancestral burial sites and could not be abandoned under any circumstances without injuring the identity of his group. Even though as a young élite professional he may well work elsewhere in the country, he argued with total conviction, 'I belong to that land'.

Early days of colonial development in the Highlands showed a willingness to part with disputed areas of no-man's land between previously warring groups. The whites, being a neutral party, could take over land where each side had claims and act as a buffer. Later on, the people saw economic potential in what had been waste land. 
Pacification was generally a welcome relief from the constant wariness of pre-colonial times. Fighting had often been much more than ritual defiance or restrained competition between closely allied groups, and on occasion led to the dispersion of some groups from their land or even to their total elimination. Another important benefit expected from co-operation with the white officials and settlers was material gain. Economic prosperity cannot be separated from group prestige, and perhaps the main aim of intense cash-cropping, cattle projects and motor vehicle purchase is to increase the status of the group $v i s-a ̀-v i s$ its neighbours and rivals.

Intense smallholder economic development failed to meet the high expectations of wealth and is now regarded with a degree of disillusionment. Nonetheless land pressures are more intense than ever. The alienation of land for towns, roads, mission stations, and plantations is now resented, especially since the sudden introduction of the cash economy in the last twenty years has reoriented the nature and the scale of the competitive, traditional inter-group exchanges. The instability of prices for cash crops such as tea, coffee, and pyrethrum (and the inflated prices for traditional valuables, such as pigs) only increases disillusionment and greed for more land as an insurance against a collapse of the market. The disappointing results of smallholder cash-cropping convinced the people that the wealth of the white men remains unattainable, and this could be a prime contributing factor in the desire for cattle projects even in an area as short of land as the Kamanegu of the Singga Valley in the Chimbu District.

In pre-colonial times areas such as the Chimbu had already an extreme population density, reflected in the frequent use of very steep mountain slopes for subsistence gardening (see Brookfield and Brown 1963; Brown 1972 and Criper 1967). Added to these pressures there are now growing populations arising from the cessation of warfare, improved public health, and nutrition. Furthermore, peace has meant that people are starting to live as nuclear families. The segregation of the sexes is breaking down as there is less need for the men to constantly defend the group, and this is leading to a change in sexual mores and certainly to a breakdown of traditional constraints which limited the birthrate. With an acute awareness of the increased pressures of numbers, leaders are looking to provide land for their 
descendants, anticipating demands which may go beyond immediate needs, but which are nonetheless readily foreseeable.

Even the most intense family planning program would take a long time to halt the acceleration of the birthrate (and the increase in land requirements it implies). Migration is one outlet, but it is presently merely a safety-valve, which usually leads to increased pressures elsewhere, especially in the urban areas. Small numbers of settlers are acceptable in some other Highlands areas and in many coastal areas, but intensive resettlement programs (as well as an uncontrolled urban drift) involving large numbers have created problems in social relations with the host populations and will create demands for new land by the progeny of the settlers themselves. As neither an agricultural nor an industrial revolution is likely to occur in the Highlands in the near future, it is all the more important to consider whether and how it may be possible to influence at least the political factors impinging on the land problems in this area.

Due to rapid and intense colonial penetration, political change has been immense. At first the powers and prerogatives of traditional leaders were boosted beyond what would traditionally have been acceptable, and reinforced with the power of the new Government in the form of the kiap, the police, and courts. This has been varied with the installation of Local Government Councils which seek to combine frequently immiscible sub-clans, clans, and even tribes into single political units. Lacking police powers and formal judicial functions, councillors have often not been respected within their own ward (let alone the entire council area), and have not been able to fulfil a necessary function of maintaining public order. Often, too, they are middle-aged men with little traditional prestige but some experience of the modern world, yet not enough educational skills to grasp fully the societal change occurring around them or to earn the respect of even the semi-educated young.

Since a large proportion of children drop out or are involuntarily excluded from schools, there is a growing group of people ill adapted to village life and traditional social control but also poorly equipped for the overstretched modern urban economy. These people are frequently involved in clashes with their elders and with members of other groups, and this leads to many more opportunities for intra- and 
inter-group disputes. The wandering young seek greater excitement to fill their bored days. As they cannot prove their manhood in the customary manner on the battlefield, and aided by alcohol, many become bar-room warriors. Still existing group solidarity means this immediately involves other members of their own political or language unit. Additionally, the older men perceive a threat not only to their own leadership position in the community but also to the identity. of their traditional political unit. Hence they seek to reinforce the group, and land claims and tribal fighting have these effects.

Potential causes of conflict are always present with the intense interaction between contiguous groups, but the fact of recent reversions to fighting in some conflicts indicates and accelerates a declining government control over the area. A straying pig destroys a garden, an enthusiastic suitor impregnates a girl before marriage, a couple commits adultery, a man makes a garden on or takes pandanus nuts from another group's land. In the past such disputes have been largely contained (despite threats and shows of strength as part of the normal ploys of inter-group politics). Swift and simple intervention by the jack-of-all-governmental-trades, the kiap, has usually settled them ad interim. But now the kiap is hemmed in both by legal rules and specialist colleagues entering into aspects of his previous work. Overworked and office bound, he often cannot be in touch with impending problems and feels constrained by outside observers and the growing sophistication of the population. More recently still, as a member of a departing colonial government, he feels he lacks the support of his metropolitan government and thus does not necessarily act with his full vigour and determination. There is a growing awareness among the population at large that government is losing its punch. One reflection of this is a number of unsettled land disputes long delayed before Land Titles Commission hearings, or subject to appeal. Frequently the activities of indigenous Demarcation Committees are regarded as biased, and sometimes the rulings of the Commission remain unenforced by kiap or police (see Hide 1973).

'The white man's way is no good, we must settle things in our own way!' was allegedly said by one of the instigators of the Gena-Sikou clashes at Kerowagi in 1972. He had some credibility, as the administrative and legal action had continued since the early 1950s, and resulted 
from uncompleted conquest and expansion under way forty years ago when colonial contact froze the tribal boundaries (see Standish 1973b). In another incident in late 1972 a patrol officer from Kerowagi marking a generally undisputed border was bodily put in the river. 'That's where the border is', members of one of the groups told him. Some survey patrols in the Chimbu have had to be abandoned because of local hostility.

The new indigenous Government is not expected by Highlanders to fare any better. The National Coalition has not yet become seen by them as a government 'of the people'. Given the communal divisions and communication difficulties, it is not surprising that public awareness of national politics is low. This is compounded by lack of any political mass movement to articulate sentiments and integrate group pressures into the political system. Local politicians and councillors are not seen as controlling the Government, which is an alien and often incomprehensible institution. There is no sense of local participation in guiding the destiny of the district or the nation, nor indeed much sense of responsibility of politicians to their electors. Government belongs to someone else, and can be implored but not forced to act.

The expected departure of expatriates with self-government and the localisation of key positions in the bureaucracy are greeted with some apprehension. It is not often expected that local officers will be respected, because of their youth or their imputed bias. Some clan leaders argue that an outside man (such as a coastal) could be fair and firm, but these men all have to prove their own merits, while an expatriate is generally accepted until proven inadequate. Administratively the situation one of an inevitable decline of performance with a rapid turnover of staff which reduces the knowledge of local problems as well as the local peoples' familiarity with and confidence in officials.

Their current questioning of government includes challenges to police authority. People can detect police arbitrariness and lack of discipline. Rural people in the Highlands have little contact with police except in times of trouble, and there is little opportunity for a relationship of mutual trust to develop. Much crime goes undetected, and even when convictions are achieved, the introduced system of imprisonment does not conform to indigenous values which stress compensation for the aggrieved rather than punishment for the offen- 
der. A number of disturbances or fights have been too large for the police to handle, and their loss of face has led to a declining faith in government as a whole.

Given this situation, land becomes increasingly the main element providing security for the group, both in terms of basic survival and economic standing in the community. The response of different groups and their leaders to the approach of self-government and independence appears to be strongly influenced by their situation regarding land holdings, and their self-perception as political (and perhaps quasimilitary) actors in the new state. The colonial intrusion halted a dynamic process of expansion and retraction, relocation and dissolution of groups.

Those groups such as the Gena of Kerowagi or the seriously overcrowded Kamanegu of Kundiawa-who were both expanding in the 1930 s when fighting was stopped-feel some cause to resent the intrusion. They certainly want to regain some of the land they had conquered at that time but which government officials returned to their rival neighbours, the Sikou and Endugwa respectively. Through the 1950 s and early 1960 s there were occasional eruptions of fighting and lengthy legal battles. The Sikou and Endugwa filed counter-claims, and the matters were subject to Land Titles Commission rulings in January 1973. The Gena had made their point in battle on 19-20 July 1972, won the land they claimed in a test case, and had to compensate Sikou for valuable trees and improvements (Application Nos. 1972/16770).

In the Kamanegu-Endugwa matter, Commissioner H. J. McKenzies ruled to retain the status quo (Application Nos. 1972/325, 499, 166, 165). Initially it seemed his decision would be accepted. However, following a motor accident in which a Kamanegu driver killed two Endugwa and injured another in March 1973, tensions between the tribes increased greatly. Rapid steps towards early compensation eased the tension somewhat, but general abuse and a hot speech at a compensation ceremony led on 2 July 1973 to a brief outburst of fighting at Kundiawa market, which was quickly broken up by the District Commissioner and a Police Mobile ('Riot') Squad. There were small scattered outbreaks of fighting and a panic exodus of both tribes from the town. Observers are sure both sides intended a show of 
strength. The Endugwa elders have not dropped their claim, are educating their young in the old boundaries and ancestral sites, and have been making preparations for a massive pig killing ceremony which will strengthen internal tribal feeling and external alliances. The dispute will take many years to resolve.

In the cases mentioned, the group with the greater population and stronger traditional and modernising leadership is much more agreeable to the coming of self-government and independence than those groups which have been on the defensive for the forty years of colonialism. Thus, the Sikou are in general more conservative, while some Gena leaders are keener for rapid political change. Other factors than land are involved in these cases, but some Kamanegu and Endugwa leaders have made interesting comments directly inter-relating land matters and constitutional change. Some Kamanegu argue that their land situation will improve with self-government, and some Endugwa say that self-government can come-provided they get their stolen land back first. By contrast, the nearby Naregu are relatively well supplied with land, and almost to a man they implacably oppose the withdrawal of the Australian presence. In all these cases attitudes to political development show a direct if loose relationship with the land problems of the groups involved.

Similar impressions are felt by observers in the Mt Hagen town area, where the groups with strongest feelings of dispossession are reputed to be the most anti-colonial in their behaviour. Certainly clan clashes (such as the Jiga-Yamuga disputes) around Hagen town relate directly to intense land shortages from sales to whites which are now regretted. This is not to say that animosity is limited to people short of land, but that people are worried about land for the present and future and are therefore more likely to be in conflict. Intense land pressures and fighting are also said to be closely inter-related in the Wabag region of the new Enga District.

Confusion about political change is reflected in self-contradictory attitudes throughout the Highlands. Suppressed resentment of expatriate affuence, political influence, and overall domination of the economy occasionally breaks through in the stoning of vehicles and other harassment. This resentment is shared by community leaders who simultaneously tell the white men not to go. The Highlanders say they 
are not ready for an independent Papua New Guinea. Their colonial dependent attitudes reflect hope of gaining a stronger position vis-à-vis coastals if change is delayed. But they are now being challenged in the towns by a few more educated radical youth, some of whom have developed a coherent anti-colonial interpretation, arguing that land problems, fighting, and social distuption generally are the direct result of colonialism. They say that the size of local political units and alliances is now greater than ever before, and the pressure so much more intense. Rapid escalation of small squabbles thus occurs, aided by the mobility given by the 'colonial' road network and motor trucks. Young men come to town because they have been schooled out of their own society and they are beyond the social controls of the past.

They are seen by their elders as 'lost men', and are seeking leadership in their plight. It is not coming from the clan, the local government, or the central government at present. Unable to get land to start businesses at home, or unwilling to do the necessary physical work and unskilled or unemployable in the tiny industrial sector, they are a potential revolutionary force existing in a leadership vacuum.

Papua New Guinea is still searching for workable approaches towards settling land problems. Throughout the country, the Commission of Inquiry into Land Matters has received calls for a delay in self-government and independence until land problems are settled further. Highlands leaders asked for the Commission to recommend extremely firm measures on agitators in land disputes. They also demanded tough action on tribal fighting. Resolute action will be required of the new indigenous Government, but it must be combined with strong political leadership and widespread mobilisation. Present concern over land matters has reached an excessive pitch because of rapid economic and social change in the colonial era and the dislocation of the traditional economy and political system. Land provides security in a period of social upheaval. If political leadership can instil a greater sense of security in the community, land problems may be reduced. 


\title{
I7 Indefeasibility and justice
}

\author{
W. Kaputin
}

The 'doctrine of indefeasible title' is one of the key principles of modern land registration. It means that the court will not look behind a certificate of title which has been conferred on the holder. Once land has been registered, the certificate gives conclusive evidence of title which can never be successfully challenged or disputed by some other claimant. The Tolai people of New Britain's Gazelle Peninsula view this 'doctrine' with contempt-and they have good cause for doing so.

The Tolai value their land a great deal. No land was ever known to them as 'waste land' or 'no-man's' land. All land has always been traditionally owned. When the colonialists intruded into Tolai society, they took advantage of the people's ignorance and backwardness and grabbed large tracts of Tolai land (for the historical background see Epstein 1969; Sack 1973; and Salisbury 1970). Most of these unjust acquisitions are now protected by indefeasible titles.

In many cases the colonialists paid salt, nails, tobacco, axes, and laplaps for the land. According to English law this may amount to a legal transaction, involving a movement of consideration from one party to another. But by any standards of natural justice these things were obviously a totally inadequate consideration for the land the colonists wanted to buy. In English law (or for that matter with regard to mere commonsense), if consideration is inadequate, and the dominant party takes advantage of the other's ignorance, the transaction can be set aside in the interests of justice. Why the hell then do the courts or the Government do nothing about it? The Tolai need not resort to legal reasoning to understand that their land has been unjustly alienated from them. It is far from logical from their point of view that the law instead protects the foreigners' title to such land.

In other cases the Tolai allowed some of their land to be used by foreigners on the understanding that it would be returned when it was no longer required. This was a traditional practice among Tolai. It would be an act of goodwill and good faith on the patt of the foreigners concerned to return this land from which they have benefited 
for so long. Instead they have fraudulently managed to register this Tolai land and have obtained indefeasible titles to it.

Moreover, some of the land which is now in foreign hands was apparently stolen from the Tolai. During the era of early colonisation the foreigners had guns, and one does not have to think hard to imagine what the situation was like. For a government to enact laws to protect these titles is almost beyond human comprehension.

Yet instead of curing the injustices of the original land acquisition the Government enacted legislation to entrench them further. The New Guinea Land Titles Restoration Ordinance 1951-1966 is such a piece of legislation. It provides for the compilation of new registers and official records relating to land in place of those lost or destroyed during World War II. This Ordinance has seriously aggravated the situation. First of all it did not require a foreign claimant to show that the original acquisition of the land from its Tolai owners had been valid before restoring his title. Second, it raised false hopes among the Tolai that this was the intention-since investigations were made as to whether the interested Tolai objected to a restoration of title. Third, it even allowed foreign claimants who had so far been unable to get a registered title to obtain one-under the guise of restoration-and with amazing ease. No one studying this Ordinance will fail to see how light the onus of proof upon the foreign claimant is and how simple it is for him to have a piece of land registered in his name. Without having to show any concrete evidence that a proper transaction did ever take place, he can get an indefeasible title.

In the past the Tolai have been going in vain to the courts over land rights, but the courts have always turned their claims down, because of this 'doctrine of indefeasibility' (for a fuller discussion of this question see Hookey 1973). With the government and the administration of justice all in colonialist hands, it is not hard to see why indefeasibility and enforceability of titles have so far always worked in favour of the colonialists. But is this justice? And is it surprising that the Tolai sometimes resort to violence in their frustration? The current attitude in the Gazelle is that the Tolai reject courts; they no longer believe that courts can give them true justice.

Since it is the 'doctrine of indefeasible title' which stands in the path of justice, it will have to give way, and since the courts will not 
be able to find a just, acceptable, and practicable solution, all the original transactions must be set aside also. Shortly after World War II it might have been sufficient to re-examine the validity of individual land acquisitions made by foreigners in the past instead of simply restoring their titles. Today a much blunter political approach is needed. At least in the Gazelle it will be necessary to re-negotiate all land acquisitions made by foreigners up until World War II. This will mean in effect that the original Tolai owners, if they want their land back, will have to pay a reasonable compensation to the foreign claimant for any improvemients on the land. On the other hand, if they agree to accept the foreigner as the owner, he must compensate them for the land according to the true value it had at the time when it was first acquired by him or his predecessors.

These re-negotiations do not mean that the doctrine of indefeasible title' should be abandoned altogether. On the contrary, it is vital for the land law of this country. But it can only be employed when both parties know their rights and can negotiate at arm's length with each other. This stage was not reached when the original acquisitions were made, but it is reached now, and for this reason the result of the suggested re-negotiations between Tolai owners and foreign claimants should be immediately registered and clothed with indefeasible title.

Some people believe that the Tolai would never respect any titles if they were allowed to upset these old land transactions. I do not think this is a strong argument. It was certainly not regarded as such when the Australians expropriated the German claimants after World War I. It is also not true. In fact a re-negotiation of past acquisitions today is essential if the Tolai are to respect titles in the future. How can the 'doctrine of indefeasible title' survive if it is used to cover up general injustice? I am sure that the Tolai will continue to demand justice if these unjust titles are upheld. I am equally sure that they will respect titles which are based on fair negotiations between equal partners. There is little chance that the Tolai in fifty or so years will demand new negotiations. By now they have become sophisticated and have received some education. This enables them to understand fully what land transactions involve. This appreciation will stop them from telling their children that their land has not been properly acquired and therefore prevent them from embarking on unscrupulous means 
of getting it back. It is thus not only justice but also prudence which demands re-negotiations at this stage.

There is another important factor which will protect titles in the future. The re-negotiation of past land acquisition will require legislation to be enacted by the new indigenous Government. Instead of reluctantly having to back up colonial legislation which was imposed on this country without regard to its traditional laws and which is applied to transactions of which it does not approve, the new indigenous Government will now take full responsibility for its own laws. It will witness any transactions that result and, because of this, it will be in a position to afford due protection to any titles based on such transactions.

On the other hand, for the new indigenous Government merely to re-enforce pre-war titles would be dangerous as well as invidious. What we have seen happening in the Gazelle and what will also happen in time in other parts of this country is a product of the various inroads which the colonial Government was pursuing in its dubious attempt to secure justice in favour of the foreigners. It is the people, through no volition of their own, who now suffer the injustices created during the colonial era. This situation, not only on the Gazelle but also elsewhere in this country, must be corrected now by the true indigenous Government. If it ignores the whispers in the wind, it will not sutvive for long.

In the final analysis, it would seem that the Torrens system which confers indefeasibility of titles was introduced into this country primarily to protect the interests of the foreign minority. I suppose it is a truism to allege that the colonial Government and the courts knew very well that these titles stemmed from uncertain, doubtful, and suspicious claims. If the Australian Government wants to protect these foreign interests as it has been doing in the past, then it must do something about the problems which this attitude has created for the people. Judging by political trends currently existing on the Gazelle, it seems that these foreign interests could be at stake. This is not the fault of the people nor of the Torrens system: it is the fault of the Australian Government and its colonial Administration which have so far refused to do justice to the people and to the doctrine of indefeasible title'. 
In conclusion, I a Tolai, voice here a cry from the depths of despair to which the Tolai people have been reduced in their struggle for justice over land; now they appear to be totally disillusioned, alienated from the fountain of justice from which they were meant to drink. 


\title{
I8 Alienation and identity
}

\author{
P. G. Sack
}

In Papua New Guinea the term 'alienated land' means broadly all land claimed by expatriates, including the Administration. It refers in particular to large areas of land which Europeans acquired for townships or plantations in the early days of the country's colonial history. Small plots acquired for mission and trading stations and the like and also large areas which were recently purchased are as yet not seen as a practical problem.

Why is alienated land regarded as a problem? First of all, many Papua New Guineans feel that since ail land in this country belonged to them before the Europeans came, they should again own all land at Independence. They also believe that all early European land acquisitions were unjust, no matter whether the land was confiscated, taken into possession as ownerless, or bought for trade goods. Moreover, they are convinced that by acquiring the land from their forefathers the Europeans robbed them of the opportunity of utilising its full economic potential. To look at alienated land also hurts the people's pride, because they feel their forefathers were treated as inferiors by the Europeans, and it makes them at the same time ashamed that their forefathers were ignorant enough to be 'tricked' in this way.

To solve the problem of alienated land, and to solve it before Independence, is probably regarded as the single most important obligation of the outgoing Administration and, more and more, the Australian Government. It is seen as a colonial mess which Papua New Guinea refuses to inherit. It is also seen as a purely black and white problem, in terms both of the people involved and of legal and moral responsibility. The gradual blurring of its outlines, through the indigenisation of the Administration and the transfer of alienated land to indigenous settlers, is watched with some apprehension. Papua New Guineans further believe that any compensation to be paid to customary owners or to expatriate claimants is a matter for the Government of 
Australia and that they should not bear the international responsibility for a possible expropriation of the latter.

In theory there are many possible solutions to the problem of alienated land (for a comparative historical survey see Sanders 1973). They range from a complete disregard for the interests of the customary owners to a complete disregard for the interests of the expatriate claimants. It could be decided that it was too late to attack any of the land acquisitions and that the original owners were also not entitled to any compensation, or it could be decided that all alienated lands, including improvements, should be expropriated and returned to their original owners without any compensation to the expatriate claimants. These extremes could be softened by compensation payments for the land and/or improvements at varying rates to either the original owners or the expatriate claimants.

Another extreme approach would be for the Administration to take over all alienated land-with or without compensation to original ownets and expatriate claimants-and to use it in the 'national interest' by providing land for settlers from overpopulated areas, or for promising indigenous enterprises, etc. The bluntest solution would probably be to uphold all claims but to insist on a lump sum payment from the Australian Government to compensate for all legal and moral shortcomings of land acquisitions in the past and to administer this money as a national fund in the interest of those Papua New Guineans who are suffering hardship as a result of these acquisitions; for instance by providing finance for the re-purchase of plantations, the building of office blocks for letting, the construction of roads to open up new areas for cash-cropping, or for the development of community centres for villages swallowed up by towns, etc. A more modest version of this fund idea could also be used if compensation were paid to the original owners of alienated land: instead of distributing cash, the compensation payment could be administered as an investment fund by, with, or for the owners.

The alienation of land has been recognised as a problem since the first Europeans arrived in this country. All colonial administrations have grappled with it, but all without success. This is not surprising, as the problem is in a way as insoluble as it was unavoidable. Alienated land became a symbol for colonialism, and at least this symbolic aspect 
of the problem cannot be solved, since history cannot be undone. At this psychological level the problem can only be outgrown. It will become irrelevant when the people have found a new identity. Until then it will remain a pain in the neck whatever is done.

This is not to say that nothing can be done or that what will be done is not important. On the contrary, it must be realised that as part of the problem is symbolic, part of the solution must be and can be no more than symbolic. The problem is largely a problem of burying the colonial past and of bringing the people in their own eyes on to an equal footing with the rest of the world and in particular with their former colonial masters. A solution for the problem of alienated land cannot be seen merely as a return of lost property or a compensation for an economic loss; it must also be an atonement for injured dignity.

Seen in this light, the problem not only concerns those who have lost land as a result of alienation but affects the people as a whole. It is probably most strongly felt by the educated élite, who are weathering the most serious identity crisis, and not by those who have suffered most from the practical effects of land alienation. It is therefore essential for the people to understand that the problem of alienated land is not simply a matter of rectifying the injustices of their colonial past, but that the way in which this is done is crucial for their own future. Alienated land is more than a symbol of foreign colonialism; it stands also for a certain type of economic development, in the past as well as in the future.

It may seem to be a simple demand of justice that people who 'sold' their land in the past for a few trifles without really knowing what they were doing should be compensated for their loss by being paid its current value. But to try to remedy the 'injustices of colonial capitalism' with 'capitalistic' means is not only self-contradictory, it also involves the acceptance of 'capitalistic' values for the future. To believe that it is possible to do one without the other is merely another manifestation of decolonisation schizophrenia. A government which claims to be committed to social justice and equality must lose its credibility if it allows millions of dollars to be paid as compensation for lost land to a few lucky people who have done nothing to improve its value-even if the money does not come out of its own pocket.

It is an illusion that the past and the future can be treated in entirely 
different ways or that the problem of early European land acquisitions can be solved in isolation. This applies in particular to the argument that the price paid for land by Europeans in the early days was immorally low. There are already Highlanders who demand the return of land transferred to other groups in pre-contact days because the 'payment' of pigs and valuables was inadequate considering its present economic potential. And the people around Cape Hoskins who recently sold good agricultural land for a few dollars per acre may well feel a sense of injustice if some of their fellow-citizens are paid thousands in compensation for traditionally rather useless land, merely because it now happens to be in the centre of Port Moresby. What was the true value of this land when it was acquired almost a hundred years ago? How does one assess the value of the first steel axe to a subsistence gardener? And the value of a stretch of virgin bush to a prospective planter who feels that he can choose from hundreds of thousands of acres and that the work and the expense involved in developing the land will contribute a great deal more to his future earnings than the land itself?

From a purely economic point of view, are the Tolai today not better off than they were before the Europeans came-although they lost more than a third of their land? Should they not blame their present land shortage instead on the doctors who cut down infant mortality, the missionaries who prevented them from continuing their traditional methods of population control, and their own eagerness to plant cashcrops, as well as on the fact that they can no longer use their numbers to force the Baining further into the mountains? (See Granger 1971.)

Moreover, it should not be overlooked that there are many groups in Papua New Guinea who are either quite happy to accept the past alienation of part of their land or who even now would gladly alienate part of their land to outside interests, if this meant roads to transport their own cash-crops, or wage labour on the spot; in short, economic development. Western 'capitalism' may be what the people of Papua New Guinea want for themselves in the future. It is, in any case, not more different from their traditional attitudes than 'communism' in the Western sense. It is clear, however, that the people will have to make a decision as to where they want to go-which does not imply that they have to choose between 'capitalism' and 'communism'. 
Whatever the decision, its implementation will be difficult and will have many unpopular results. Papua New Guinea's future cannot be shaped without hurting people, without favouring some and disadvantaging others. A simple, straight-forward political program has probably the greatest chance of success. To gain the crucial active support of the people, even if it is at first only a minority, the goals Papua New Guinea is setting out to achieve must be brought into the open-and not merely in the form of vague general and of ten negative political statements. At least some concrete plans have to be put forward which will demonstrate to the people how the broad aims affect them in practice. To muddle in the dark and to concentrate on putting out fires which have already been started will in the end disappoint everybody. It may avoid opposition, but only at the expense of not gaining public support. Besides, to keep on creating facts without following a clear plan will whittle away what freedom of choice exists at present. In a few years time it may require a revolution to change a situation no one really wanted to bring about.

If the Government of Papua New Guinea wants to demonstrate to the people where it is going to lead them, the problem of alienated land would be a good example. To assist the people in buying back a few plantations, to offer more generous compensation and to return some 'waste and vacant' land, but to defend, at the same time, the rights of indigenous settlers on alienated land against indigenous claimants and to fight some of their land appeals in court will not only achieve little but spoil a great opportunity. Even to obtain a few million dollars from the Australian Government in semi-secret negotiations will not do much good, unless it is demanded and given in the right spirit. Money is the least of Papua New Guinea's worries. What is crucial is a strong belief of the people in themselves and their future, based on an honest assessment of their past. The way in which the problem of alienated land will be handled will have importantpositive or negative-results in this respect.

All this may suggest that it is a sober judicial approach to the problem of alienated land which is really needed. This is not so. A judicial approach would certainly have advantages but they are probably outweighed by its shortcomings. First of all, a judicial approach would be far too slow and time consuming. More importantly, however, it would be frequently impossible to assemble sufficient 
oral or documentary evidence to decide a case on its own merits. Besides, the general criteria on which these individual decisions must be based would have to be defined by way of legislation so that the basic decisions would, in any event, be political rather than judicial.

A bold political approach has two main dangers: that insufficient regard will be given to the wider implications of the decisions which are being made, and that these decisions will be based on fiction rather than fact. Solutions which seem unproblematic as long as they are simply seen in terms of innocent native victims versus arrogant colonial exploiters and suppressors can become rather embarrassing when it is realised that similar problems can arise between an independent government and the people or between different groups of Papua New Guineans. Anti-colonial sentiments can easily turn into antigovernment feelings, and today's belief that the whites (or Chinese) have no right to be here may tomorrow be directed against another minority group.

A bold political approach to the problem of alienated land can thus well prejudice certain courses of action Papua New Guinea may wish to take in other contexts. It can also prevent the people of Papua New Guinea from really coming to grips with their colonial and precolonial history. Many Papua New Guineans have already developed a half-idealised and half-perverted view of their traditional land tenure systems which is so far divorced from the facts that it must cause trouble. Minor and rather exceptional colonial cruelties are blown up out of all proportion, but even then they remain mere trifles compared with what the colonial powers in fact did to each other over the centuries. Colonialism is not the root of all evil. History in general is not a ladies' tea party, and there is no deadlier sin for an emerging nation than to feel sorry for itself. In a way the people of Papua New Guinea would be better off if history had made them suffer harder. They would then have developed a greater eagerness to fight for their future.

The problem of alienated land looks simple but it involves many different questions which may demand very different answers. It is so tempting to treat the alienation of land as a scapegoat for all real and imaginary sins of colonialism. But the scapegoat is likely to return as a Trojan Horse after Independence. To beware of the Greeks bringing gifts may be wiser than to ask them for more. 


\title{
I9 Urban expansion and customary land
}

\author{
N.D.Oram
}

The majority of towns in developing countries are divided into two sectors: a 'modern' sector of Western urban standards, consisting of the central area and high class suburbs, and a sector of congested tenements and uncontrolled peripheral settlements. In countries where traditional systems of land tenure still persist, the boundary between the two sectors is likely to be largely, but not precisely, identical with the boundary between customary and alienated land. Towns in Papua New Guinea fit into this pattern. In the past, the colonial Administration has entirely neglected problems which arise from the development of customary land. As towns such as Lae and Rabaul can only expand into areas of customary land, these problems have now become urgent.

Towns were very small before World War II. The population of Port Moresby, for instance, consisted of some 400 Europeans, and less than a thousand indigenous migrant workers lived in the town area. Since 1947, growth has been rapid. According to the 1971 census the population of Port Moresby was 66,244, that of Lae 34,699 and that of Rabaul 24,778. Madang, Wewak, and Goroka had populations of over 10,000. A new urban complex has developed on Bougainville Island, which in 1971 had a population of over 14,000 people. Today already about 10 per cent of the population live in towns, and this percentage may well double during the next twenty years despite all attempts to discourage migration to urban areas.

There were no towns in Papua New Guinea before the Europeans came, and political units were very small. The largest of them were probably the villages in the Purari Delta, where populations reached 2000 people. The average village population did not exceed two or three hundred. Nucleated villages or hamlets were found in many coastal areas and an even more dispersed form of settlement was sometimes found in the Highlands. When Europeans reached the 
Port Moresby area in the 1870 s, for example, there were ten distinct villages situated within the present town boundaries.

Traditional systems of land tenure in areas where today's towns stand differed according to the social structure of the groups concerned. But certain aspects affecting urban development were common throughout the country. Land rights formed part of the total network of rights and obligations within groups and were therefore subject to change. The acknowledgment of individual rights by the group could, for instance, depend on the extent to which a member maintained his kinship obligations and his personal reputation. The most important traditional right, the right to cultivate land belonging to the group, could only be granted to those accepted as residential members of the land-holding group or to those who lived nearby. In practice, traditional land tenure systems were flexible. Moreover, boundaries were not rigid and rights of ten not clearly defined. As in advanced societies, for example, occupation which went long unchallenged could transform temporary rights to cultivate into rights of full ownership.

One of the first needs of British and German Administrations was land for their administrative stations. In Papua, care was taken during the first purchase at Port Moresby to explain to the people what their consent to sell their land involved. It is doubtful, however, whether the Barune people understood the implications of their sale, in 1891, of 28,000 acres of land on which part of Port Moresby town now stands. At Madang, some of the earliest German acquisitions were made in ignorance of the true land-holding groups. At Lae, 11,721 acres were claimed as ownerless. The people have tried to get their land back from the Administration, but the law and administrative action were heavily loaded against them. Land in a number of areas is still sub judice as a result of claims by descendants of the original owners. The Papua New Guinea Government will have to face the problem of the claims for the return of large areas of very valuable urban land to their original owners.

Since overseas administrations have been firmly established, little urban land has been acquired by them through compulsory acquisition. There have been exceptions: the compulsory acquisitions of the land for Taurama barracks from Pari and Kila Kila villages at Port Moresby, still partly unsettled, is a notable example. The Administra- 
tion has acquired nearly all urban land through voluntary sale but its agents have put heavy pressure on the rightholders to persuade them to sell. Not all rightholders have been unwilling to sell their land. Their desire to receive cash has often overwhelmed their sense of responsibility towards their group's land which they acknowledge belongs to past, present and future generations.

A number of changes have taken place in traditional systems of land tenure. In many areas there has been a change of use: land in or in the immediate vicinity of towns is no longer used for cultivation but for house or commercial sites. Migrants from other parts of Papua New Guinea may need land on which to build their houses. The migrants are usually given the right to occupy land through ties of kinship or friendship. They subsequently introduce their own kinsmen and people from their home areas, and ethnic settlements develop. Such settlements have appeared in or around all major towns. The local rightholders lose control of the situation. In Port Moresby, relationships between rightholders range between very good to very bad. Where relations continue to be good, customary exchanges are made between the two groups and intermarriage may occur. Many settlers pay nothing to the rightholders. Increasingly, however, regular rents are being demanded from new settlers. Holders of rights to customary land outside Goroka town boundary are charging rents of between $\$ 2$ and $\$ 6$ a month for residential sites and one man is receiving $\$ 200$ a year for a small store site.

In a number of urban areas land is being divided into smaller and smaller parcels held by smaller and smaller kin groups. Clans, for example, may lose even residuary rights to land and some clans in Port Moresby villages have lost all rights as corporate bodies to former clan land. Small blocks of land, including house sites, may be held by extended families or even by individuals. Traditional systems of tenure in urban areas have shown considerable adaptability in the face of changing conditions. They lack, however, such valuable characteristics of a modern system as security of title, surveyed boundaries, and ease of transfer. They also suffer from such disadvantages as overlapping interests, and it is almost impossible to register all those who have rights to a particular area of land.

Towns in Papua New Guinea grew up as purely expatriate centres. 
In Port Moresby, for example, the majority of Papuans (up to 1942) were required by law to live at Koke, outside the town boundary. Only a few domestic servants, subject to a strict curfew, were allowed to live in the town. As late as 1956, J. R. Winders, a Queensland local government official examining the desirability of introducing urban local government in Papua New Guinea, was able to exclude Papua New Guineans and confine his examination to the non-indigenous people who comprise the principal permanent population in town areas' (Winders 1957). Not until the late 1960 s did government officials and others regard Papua New Guineans as full members of urban communities.

Nearly all British and most other colonial administrations have considered that urban development should take place only on land alienated from indigenous rightholders. In Papua New Guinea, land was surveyed and leased to Europeans and other expatriates according to Australian practices. Standards of building and sanitation prescribed by law were also, as far as possible, those demanded in the metropolitan country. Only expatriates could afford to obtain sites and develop them. As long as the towns remained small, the exclusion of Papua New Guineans created few problems. This changed when they began to expand.

As a result of this expansion, large numbers of Papua New Guinea workers flocked to towns. Neither the Administration nor private employers, although obliged to do so by law, accommodated more than a small fraction of their migrant employees. Many settled on land of villages in the neighbourhood of the town. In Port Moresby, the number of settlements rose from eighteen in 1964 to forty in 1970. In 1964, the settlement population formed 18 per cent of the indigenous population: in 1970 the percentage had increased to 28in Lae it was as high as 36 .

Officials of the Administration described migrants living in settlements as 'squatters', using the term in the pejorative sense of people whose residence is illegal. But in this sense the majority of settlers were not squatters. Except those who occupied land acquired by the Administration, they were permitted occupants of land held under customary tenure unless the rightholders had asked them to leave. Rightholders have been extremely reluctant to do this. There have 
been occasions in Port Moresby when the Administration, at the rightholders' request, has been about to secure the eviction of settlers on their land, and then, at the last moment, the rightholders have refused to sign the necessary document. Even some of those who occupy Administration land, for example the settlers from the Gulf District at Konedobu, Port Moresby, were given permission by government officials to settle there.

There were a number of reasons for official hostility to settlements. Until the mid-1960s, the Administration was concerned that village communities should not be broken up and, as a result, discouraged permanent settlement in towns. They considered only those in employment should remain in town and, often wrongly, that settlements served as hideouts for the unemployed. Further, buildings in the settlements did not conform to the Building Rules and were ugly. Settlements were unplanned, inadequately provided with services, and were thought to constitute a danger to health.

From about 1970 official attitudes towards settlements began to change. Those responsible for housing began to realise that settlements possessed admirable as well as undesirable characteristics. They were often inhabited by homogeneous communities which maintained a measure of social control among their numbers. The main threat to public health was lack of services rather than the low standards of building. And many settlers continued to improve their houses until they reached fairly high standards. New policies were conceived. Cheap housing sites were to be made available to all those capable of settling in urban areas on which they could build houses to a standard which they could afford, however simple. The sites would be provided with basic services. In time, site owners would be encouraged to improve their houses. In Port Moresby, a comprehensive plan has been drawn up by the Department of Social Development and Home Affairs to improve existing settlements and to resettle those living in settlements which are badly situated. But a number of problems have to be overcome before all housing can be brought under control, sited according to planned layouts, and provided with basic services.

As urban expansion was only considered possible on alienated land, the boundaries of most towns coincided mainly with the limits of land acquired by the Administration. As late as 1970, when the Administra- 
tion decided to establish municipal authorities, the Consultative Committees of Lae and Rabaul excluded villages and settlements on customary land on the ground that providing these areas with services would impose too heavy a financial burden on their urban authorities. Madang unavoidably included some villages, but one, in the centre of the urban area, was excluded from the jurisdiction of the Town Council. Only the Port Moresby Committee proposed that the whole actual and potential urban area should be included within the boundary and the Administration adopted its proposal.

The policy of siting all buildings, of whatever standard, according to a planned layout can only succeed if no uncontrolled building can take place. Town Councils are responsible for enforcing building regulations, but the regulations are legally weak. For example to evict someone who has built without a permit, notices must be served on the owner, which means on the Administration if notices are served on government land, or on a large number of unidentified rightholders if customary land is involved. Moreover, virtually no attempt has been made in the past to control development on customary land, although this is by far the most important problem.

The Town Planning Ordinance 1952-1972 suffers from several weaknesses. It provides only for a system of zoning, and the Town Planning Board set up under it is not a policy-making body. Until the Ordinance was amended in 1972, its provisions were not legally enforceable. The small town planning staff forms a section within the Department of Lands, Surveys and Mines. There is no provision in the Ordinance for the participation of urban councils in planning their towns and no machinery for co-ordination between departments. A Town Planning Bill was introduced into the House of Assembly in 1966 but was withdrawn without debate. In 1969, a Town Planning and Development Bill was drafted with the aid of the Australian National Capital Development Commission. This Bill made limited provision for decentralisation of responsibility for town planning to urban authorities. The Bill has not been introduced into the House of Assembly nor has it been officially circulated for comment among those interested.

As a result of pursuing a policy of promoting urban development on alienated land alone, the Land Department has so far made no 
attempt to organise the planning of customary land. This failure may make town planning in some areas almost impossible in the future. More importantly, however, recent town planning studies have clearly shown that much of the expected development must take place on land which is still held under customary tenure.

The Government can try to purchase the required land from Papua New Guinean rightholders-and there are several strong arguments in favour of state ownership of all urban land which have nothing to do with colonialist attitudes. Rightholders, however, now realise that they lose a permanent asset if they sell their land and that the purchase price they gain in exchange is easily spent and will, in any case, appear small in a few years' time. They also see that many expatriates who have leased land from the Administration are making large profits.

Some Administration officials argue that government valuations are too low and that rightholders would sell land if prices were right. But even if the Government were prepared to increase its valuations and could afford to pay the price, it is unlikely to be able to acquire through voluntary sales all the land needed for urban expansion in the future.

The Government has wide powers under Section 18 of the Land Ordinance to acquire land compulsorily, and they could, if necessary, be further extended. But in the present political climate, compulsory purchase by the Government of large areas of customary land appears unthinkable, although this situation may change in a few years' time and the Government could work towards this end.

If outright acquisition is not possible, then the leasing of land either by the Government or by private interests or by both may be acceptable to Papua New Guinea rightholders. Some leasing of land by the Administration has occurred in the past-notably an area for the mining township Arawa on Bougainville, where the Administration had no alternative. But, generally speaking, it has opposed the leasing of land for urban purposes because it considered that the State should enjoy the profits from land it develops. It has also been argued that a system of leasing will lead to the emergence of an idle rentier class - and such a class is in fact already becoming visible. However, in the immediate future, leasing may meet the needs of Papua New Guinea society and be politically unavoidable; excessive profits could be reduced through land ratings and other forms of taxation. 
It may even be necessary to give customary rightholders far greater freedom to lease land not only to the Government but to anyone they like. Those who are legally 'natives' can already lease land from each other, and the Administration in several districts has actively encouraged such leases. Through various means, such as marriage to local women or somewhat illegal private arrangements, expatriates have also begun to acquire rights to use customary land in urban areas, as they are frequently prepared to pay more than the Administration. It would be most desirable to control these arrangements at least to some degree, and this can only be effectively done if one simple legal system of direct leasing with few basic restrictions is developed.

In addition it would be desirable to encourage customary rightholders to develop their land themselves (either for personal or commercial purposes). But land development is a complex operation in which returns have to be weighed carefully against costs. Moreover, the customary rightholders need both finance and technical assistance in the planning and surveying of their land. One possibility of overcoming these problems would be to establish a statutory corporation which could carry out development on behalf of the rightholders. But this would increase the number of bodies in an already over-complex governmental organisation. Alternatively, town councils could assume responsibility for such development. However, a great deal of persuasion may be necessary before customary rightholders will be prepared to involve themselves with governmental agencies in developing their land. The installation of basic services free of charge may prove to be a sufficient incentive.

A decision to abandon the policy of restricting urban development to alienated land and the adoption of a system of direct leasing to the Government as well as private interests raises a number of problems. First of all, the leasing of small plots demands much more survey work and also a more careful definition of rightholders. The Administration tried to solve the second problem by enabling rightholders to acquire individual freehold rights to their land through tenure conversion. Under the Land (Tenure Conversion) Ordinance all rightholders have to agree to the conversion and only six names may be registered as owners. 
The dangers created by this limitation are illustrated by the attempt of the Korobosea villagers to convert the tenure of their land. They all agreed that the land should be registered in the name of the leader of the rightholding group and were probably justified in trusting him to distribute any profits according to custom. But their legal rights would have been extinguished and the leader's heirs might not have honoured their customary obligations. These dangers could be partly avoided by recognising groups as owners but registering the land in the names of some representatives.

Group registration would be acceptable to many urban land-holding groups. Yet the vesting of too much legal authority in the hands of a few representatives could lead to internal disputes, for instance over the distribution of profits. It would therefore be necessary to establish at the same time suitable dispute-settlement machinery-and the proposed village courts could provide it.

The switch to a system of direct leasing may solve the problem of obtaining sufficient land for urban development, but the problem of planning this development remains. Rational planning involves zoning, including the setting aside of open spaces and land required for public purposes and must involve considerable areas of land. On the other hand, parcels of land held by customary groups in urban areas may be small. This creates not only the difficulty of having to persuade a large number of them to lease their land in order to obtain a sufficient area, it also creates serious problems relating to the distribution of rents. Some parcels would be developed as valuable commercial sites, others as low cost housing sites, and still others left as open spaces with no commercial value.

The only practicable way of solving the problem of rent distribution would be for the rightholders concerned to form a company and share profits according to the extent and possibly also according to the value of their landholdings. Agreement to form a company among a large number of people would be diffcult to achieve. The problem of rational planning would therefore remain even if customary land was converted to individual registered freehold land. It arises as a result of a basic conflict between public and private interests, whether individual or communal. Private interests are generally reluctant to accept limitations on the use of their land which might be imposed for the 
general good. At present, their reluctance is increased by their suspicion of government intentions over land.

If a policy of pooling land and rewarding rightholders on a pro rata basis fails, town planning may have to be given lower priority as a goal of development. The aim may have to be limited to achieving basic planning layouts on customary land without a change of tenure, and with such provision for open space and grouping of commercial sites as the rightholders will accept. It is essential, however, that all customary land in urban areas should be brought under basic planning control. This would involve, as far as possible, the marking of a road layout on the ground by building tracks before development takes place and taking the opportunity of improving layouts in areas of existing development. Again, the provision of free basic services by the Government would encourage planning. If this were done, plans once agreed to by the rightholders should become mandatory. A new form of administrative organisation is needed to achieve this basic planning and also to help rightholders to develop their land themselves.

Under modern systems of land tenure in Western countries, administrative procedures are narrowly defined and impersonal. If the development of customary land is to be controlled, a flexible administrative structure is required capable of dealing constantly on a personal level with individuals and groups. A well-qualified and sympathetic person would have to spend much time in discussing with quite small groups the development of their land before they could be expected to reach a decision. Ground-level urban administration requires an extensive and well-trained staff and cannot be done on the cheap. There is a need in urban areas for administrative sub-units which provide a direct and personal system of administration which meets the needs of the people of the area. The Port Moresby City Council has established such a system: the town is divided into seven wards; each ward has an office, a clerk/executive officer, and a ward committee consisting of the three councillors representing the ward on the City Council and representatives of residential communities. Ward organisations have a considerable potential as organisations through which consultations about land transfers and town planning could be channelled.

A satisfactory system of land tenure at the community and municipal level can only be achieved if there is an efficient organisation at 
the central government level, which is at present lacking. Separate government departments, for example the Lands Department, District Administration, and the Land Titles Commission, frequently hampered by red tape and insufficient staff, are concerned with land matters in urban areas. Other departments and urban councils provide services. There is little co-ordination of the activities of these bodies at the central government or town level and no organisation at the community or village level. Co-ordination of activities relating to land would be improved if a Commissioner for Urban Development with a general oversight over urban development, as proposed by the Australian National Capital Development Commission, were appointed.

Sound urban expansion can only take place in Papua New Guinea if the problem of promoting planned development on customary land is overcome. Ways of doing this can only be found after all relevant factors, including political factors, have been considered. At present, it is probable that the only means by which land can be made available for urban expansion is for the Government or others to lease it from the customary rightholders. Attempts to plan development on customary land have failed in the past largely because staff and resources have not been available to explain to groups and individuals the issues involved and the courses open to them. If the Government wishes to ensure that all its urban areas are developed in an orderly way which meets the needs of the people, it will be obliged to devote considerable thought, staff, and finance to the development of customary land. 


\section{Mining bitterness}

\section{J. Dove, T. Miriung, M. Togolo}

The immense copper project on Bougainville which is supposed to pay for much of the future of this country is at the same time its greatest colonial legacy. Especially the events surrounding the resumption of land for the project-a woman grappling with police, the teargassing of the people, police poised above the ground to watch the survey pegs-will always be poignant reminders of the true character of the so-called negotiations between the people and the Administration. For it must be stressed right at the beginning that the responsibility for what happened lies primarily with the Administration and not with the copper company. What it failed to achieve by peaceful means, it determined to achieve by resorting to force. It is almost impossible to understand that, in the age of decolonisation, democracy, and advanced technology, a government could resort to such crude forms of demands from simple, defenceless people whose very livelihood was at stake.

The Administration's actions gave a lie to its role as a protector of the people's rights and interests. It was all too clear that economic expediency was uppermost in its thinking; the welfare of the people was accorded a mere token consideration. Among a people who base decisions on consensus brought about by discussions, the Administration was using dictates incomprehensible to their reasoning. To those who love peace and harmony and prefer orderly and voluntary development, the Administration appears as a merciless intruder into the lives of the people. It aroused bitterness, apprehension, and disorder - a result which clearly shows that any approach to development which is not aimed at improving the welfare of the people and is supported by them should be discouraged in this country. Had the Administration prepared the people adequately to understand the situation before 'negotiations' took place, it would not have found them so 'stubborn, ignorant and irrational' in their stand, but the methods used were pure colonial suppression.

In Bougainville land is private property usually owned by a clan. 
The acquisition of such land must necessarily lead to long and careful negotiations as every member of the clan concerned has to be made well aware of the whole matter, since any land transaction requires the consensus of the whole clan. Land is everything to our people. As they say:

Land is our life. Land is our physical life-food and sustenance. Land is our social life; it is marriage; it is status; it is security; it is politics; in fact, it is our only world. When you [the Administration] take our land, you cut away the very heart of our existence. We have little or no experience of social survival detached from the land. For us to be completely landless is a nightmare which no dollar in the pocket or dollar in the bank will allay; we are a threatened people.

When land is very important to a group of people, it is useless for a government to tell them that it acquires land to solve a national financial problem. How can a government make a group suffer for a myth that is called 'nation'? For those of us who are immediately affected, the concept 'nation' is a myth. The land and those of us who own rights to the land should be the nation. There was no prior consultation before land was acquired or before a prospecting authority was granted to the company over the land of the Nasioi people of Panguna. Nor did the Administration consult the people of Rorovana before allowing the company to occupy their land-in an attempt to fulfil its commitments under the Mining (Bougainville Copper Agreement) Ordinance, of whose existence we had no knowledge whatsoever.

Our people's feeling for the land and their identification with it is something that cannot be well expressed in words. The Western concept of land is different from the one we hold. To the Westerner land is a natural resource, a factor of production, and something objective and used as such. In other words, there is no intimacy between the land and the owner. Our people conceive land not only as a factor of production but as something more. Our political, social, and economic life depends on land. Our involvement with land is both physical and emotional. Land-ownership has prestige attachment, not only in terms of what it produces or can produce, but also in terms of 
just owning the land, whether it is productive or not. Unless a Western kiap understands this he is not in the position to negotiate for land. The lack of this knowledge was shown clearly by the fact that the kiaps were automatically prone to put forward blatant arguments of 'economic development' and 'fast economic growth', as if achieving these ends would solve the diffcult land problems that were being created by them.

Land is not only so sacred that no hard cash can buy it, but the people's concepts in relation to a land transfer are radically different from those of the imported system of property law. A purchase of land for money can never constitute an out-and-out transfer of the traditional title, regardless of the amount bargained for. To the people, any dealing in land which purports to annihilate their customary rights to land is unacceptable and must be opposed at all costs.

We tend too often to assume, prima facie, that economic development concerned with heavy investment is necessary for the improvement of the living standard of the people. In our country this assumption should be rigorously examined before being applied and, if applied, modifications should be made to it. We speak in particular about the type of investment alienating large areas of land from the people. It is not easy-as was shown in the Kieta area of Bougainville - to try and convince people to part with their land, without causing social and even psychological upsets to them.

Though hindsight thinking may not be very effective, we like to air views from the point of view of our people of what should have been done and how some of the problems could have easily been avoided. First, at the time the copper project began, the Administration was a colonial power. Our people hardly understood the Western land laws and their harsh implications. The Administration simply took advantage of our people's ignorance. Second, it was negotiating from the position of superiority solely conferred upon it by virtue of it being the only government. It assumed a contemptuous air and was not prepared to come down to the level of the people. This made real communication almost impossible. Because of the Administration's contemptuous behaviour, the people resorted to apathy and stubbornness. Third, the Administration employed brute force to subjugate the people and to force compliance upon them. It was simply suppression, 
the motives behind which mystify the imagination. How could such a queer attitude be exhibited by a supposedly democratic Administration under the patronage of a supposedly liberal Australian Government?

Behind the people's grievances were basically two complaints, both concerned with the way in which the Administration approached the task of land resumptions. First, there was inadequate prior consultation or, more accurately, no consultation. The decisions were made in Konedobu, the administrative headquarters, and were meant to be implemented quickly. The second complaint involved the question of compensation which the people regarded as crudely unfair and an injustice to them. The land being what it is to them, unfair compensation further aggravated the already existing problems. The deals could have been salutary and the people would have been prepared to incline to a progressive attitude had the Administration made a considerate approach, warning the land owners of the probable consequences to their life and property in the process of land resumption. Again and again the people wished and told the Administration to delay negotiations. Many commentators say that the blame lay on the Administration's shoulders. We do not want to refute this claim but to point out that the hardships faced by the people, the troubles and costs to the Administration, the delays to the company, and the vexatious confrontation between the three parties, the Administration and the company on the one side and the people on the other, were avoidable had there been a more cautious approach.

It was obvious to our people that the Administration's approach was not considerate; in fact, it was openly contemptuous of the rights they possessed as the traditional and legal owners of the land. A delicate approach was what was needed; however, a delicate approach was time consuming, and time is money, and therefore economic development must not be retarded. The Administration was flagrantly dishonouring the obligation which it undertook at the beginning of the colonial era, that is to protect the people, their land and social milieu from the effects of malevolent and greedy Western capitalistic development.

This highhanded and misguided approach instigated a grave suspicion among the land owners. For this reason it should be condemned as doing gross injustice to the people. If the proposed 'economic 
development' was for the good of the people of Papua New Guinea, then a certain people should not have been made a focus of injustice in terms of unjust compensation, brutal axing away of their land, turning a deaf ear to their grievances, and threatening to use force against them.

More open clashes between the people and the police were avoided, partly because the people restrained themselves and also due to the calibre and leadership of such people as Paul Lapun and Raphael Bele who adopted a strategy that no trouble would ensue unless it was incited by the police. ${ }^{1}$ Moreover, many of the policemen who were employed in that strange situation seemed sympathetic towards the people who were clearly putting up a just fight for their land. The Administration through its network of radios lauded the police for great restraint and tact. If it conferred all the merit for the evasion of more open clashes on the police, then its implications were that the people were putting up a barbaric fight, that they were pigheaded and troublemakers.

If it was acting upon a principle, the Administration itself endangered its successful application by a savage approach. This principle, no matter of what type or nature, whether it rested upon a basis of law, whether it was supported by the Australian Government, or whether it simply arose from economic contingencies, was doing something to the people by which they were aggrieved. For is it not that the people based everything they did on land, and is it not that depriving them of their land was tantamount to killing them? The approach of the Administration infringed a basic moral and ethical principle, it refused to honour the people's rights as human beings and as citizens of the country by dictating to them in terms clearly unjust.

The Administration, in the first place, was not prepared to gauge whether the people were at all disposed to part with their land. Having failed in this objective, it put a blanket-cover over the problems implicit in the people's relationship with their land. This refusal to admit that land was valuable to the people amounted to a frontal attack

1 Paul Lapun is currently Minister for Mines, and Raphael Bele Member for Central Bougainville. 
on the very fabric of the indigenous society. In trying to achieve a certain end, whatever it may have been, the Administration was using actions that were savage and directed against the people as well as their culture.

With the moral support of the company, the Administration all the time assumed that to give land to the company to be used for economic development would be 'for the good of the people'. When examined closely, the so-called 'benefits' oozing out from the mining development seem very superficial. The concentration of many thousands of workers in a small area has created many social problems previously unknown to the Bougainville people. The industrial profanities were concealed from the people; all they were told about were the 'benefits' which the mining project would bring them. Life along the coastal villages, once peaceful, can never be the same again.

There is even a graver problem brought about by the new way of life that cannot be easily remedied. The people are experiencing a deep psychological trauma in their efforts to understand the developments taking place around them and to structure a new set of values that seeks to embody these changes. Not all the outward strivings of the people are favourable and some even seem morally to be on the downturn.

These dilemmas are merely a re-creation of what has happened elsewhere where rapid development has uprooted and gravely disturbed indigenous societies. Yet it appears that the Administration flatly refused to be guided by these examples. Men have been thrown into wage employment to the detriment of the life in the villages and their family and tribal obligations. Because life in their traditional societies was so different, the sudden exposure to a completely new world has sometimes had tragic consequences for their whole existence.

Economic development that is foreign and takes its roots from external sources should try to uphold and to protect the way of life that is local. It should try as much as possible to adapt itself to local thinking and to espouse some of the local practices. What seems to be happening in Bougainville is that a handful of people will have velvet positions and lead an affluent existence in the midst of semi-subsistence local population. The new highly privileged economic class will have little to share with the local people. 
With respect to real development on the rural side: there is none. The nature of the mine is such that it feeds on local resources but does not stimulate development of new local industries. As such it cannot promote a progressive economic development. Business expertise is limited to the development of new enterprises in the urban area. Expertise that could very well be used in the development of village economies is drained away in the mining project. There is no provision made to promote light village industries. In effect, economic development is geared towards sustaining the relative affluence of the urban dwellers who will perhaps turn out to be the exploiters of the rural dwellers.

The benefits mentioned earlier should not be construed to mean a substantial uplifting in the standard of living of the people. The village people will still live in the villages while the profits from their land are repatriated to other countries. To the villagers the position is clearly that land has been compulsorily taken away from them by the Administration for the benefit of the company. Since the company is the immediate institution of the white man, their attitude toward it is a very irritated one. This attitude culminates in an irrefutable proof when they see the real benefits the company is extracting from their land, the social problems created by the company, and the many other evils arising from this kind of development. This is economic development of the Western type, based on the absurd philosophy of 'rat-race development'. There was little consideration given to the long-term lethal effects of the mine. It is not wise to anaesthetise a real problem in the short term because the repercussions of such a treatment may recur and perhaps in a much more detrimental form.

There has never been a more outrageous case in the history of this country of the Administration using force against people who did not deserve such treatment. It was dehumanising to watch the Administration take the liberty to subjugate and dispossess the people. There has been no more bizarre case in the history of Australian colonialism than this one. People were being crushed and suppressed because they stood for their rights, for their values and their dignity, for principles which they held deeply. This was not a case of the Administration reacting against a threat, in order to protect the public interest-it was rather the Administration threatening public welfare. Did the 
Administration, the rubber stamp of the Australian Government, have any right to intimidate the people to comply to its terms? Did the Australian Government have the mandate to go against the sacred rights of the people-the rights they possess as part of their culture and tradition and a way of life to which they belonged? Did it have the right to put before the people an exploitative economic system? These were the hard facts which the Administration decided to ignore.

The Administration's decision was implemented by white officialdom. Many of the officials had only a vague idea about the people of Bougainville as well as the policy they were implementing. Yet they put up a front to deceive the people into believing that major decisions would be arrived at by discussion and consensus. No one has so far asked what moral, psychological, and cultural wreckage the mining development will cause. The so-called 'progress' pertaining to the company is to be questioned. Is not the company basically extractive? Who will benefit most? Is it not the white men? Is it not the handful of people working on the mining site? The company is there to feed the financial pool of the international mining megacorporations and it employs an elaborate public relations system to placate the angry voices and preserve a good face. Our people have no idea and no knowledge of why the company went to Bougainville in areas forbidden to them, and why the Administration was so determined to protect the company's activities with its police force. The people rightly saw the Administration and the company as conspirators in a plot to rid them of their land. The indigenous land owners were alarmed just as anyone would be if strangers came and started clearing and felling trees in an area without the knowledge of the owner. Our people felt left out because they were called in for discussion only when there was an obvious problem. This was indeed strange as our people considered themselves as the real owners of the land to be exploited. It was mystifying for them to feel and hear the loud voice of the Administration taking many things for granted. It was even more confusing to see the company, with the use of heavy equipment, indiscriminately bulldoze the confiscated land.

In conclusion it must be emphasised that behind the people's complaints were two important reasons. First, they were not consulted before decisions were made and any subsequent explanations were 
inadequate and biased. The people were told only of the 'benefits', and all negative effects of the mine were concealed from them. Second, the compensation paid to them was grossly unfair. Seeing the large profits that are going to accrue to the company, the claim by the people that they were cheated is quite justifred. Again two facts must be remembered: the Administration was operating in a colonial situation, it had the sole power which it abused by mishandling the people; moreover, the Administration refused to learn from its own mistakes in handling the matter so that the people held it in deep suspicion. Its reliance on its misused powers of land confiscation only widened the existing gulf of suspicion and mistrust. The Administration the people thought was their 'protector' disowned them by employing repressive measures to alienate land from them. Batons, shields, tear gas and all the modern police paraphernalia used could have been more profitably deployed against a street revolt in some modern city than against peaceful demonstrations on the edge of a palm-fringed village.

Once more the Western law was upon the people, and men were jailed for pulling out survey pegs on what they regarded as their own land. The law confronted them with a dilemma which was not their creation. The Administration treated the land it coveted as 'Crown land', although this was not even the case according to the foreign law. The people could not say 'yes' or 'no'; but they would have lost either way. We feel it was a bad deal, and we hope it does not happen again. The Administration and its co-worker, the company, have left their landmark on the Island of Bougainville. 


\title{
2 I \\ Taming the dragon
}

\author{
J. Momis
}

At the Sixth Waigani Seminar, Mr Frank Espie, chairman of Conzinc Rio Tinto of Australia, spoke about how important the Bougainville Copper project is to Papua New Guinea, and how much it will contribute-according to Mr Espie-to our country's development (Espie 1973). Before talking about mining, though, we have to talk about the general process of development. What does it mean to say we want this country to develop? What kind of a society do we want to develop into?

The starting-point for talking about development is our vision of what society should be like: how men and women should live and how they should get along, how groups can co-exist, how the values of our society can be maintained and enhanced. In Papua New Guinea, most of us already have a good idea of the kind of values and the kind of society we want to build. We want to preserve our traditional family ties. We want to preserve the sense of group solidarity that exists in most of our societies. We want to preserve people's attachment to their land. We want improvement in the living standards of people, so that no one need go hungry, and no one need lack medical care, for example. We want the chance to improve ourselves, to learn new ways of doing things-but within the framework of our traditional values. Now, taking this vision of the sort of society we want to build, we can begin to ask how mining might—or might not-fit in.

Mining can be an important source of revenue for the Papua New Guinea Government. We cannot expect Australia-or any other country-to continue meeting more than half this nation's financial needs indefinitely. Most economists agree that it is in the best interest of Papua New Guinea to aim for increasing financial self-reliance in the long run. No nation that hopes to make choices for itself-choices as to strategies for development, for example--can afford to remain overly dependent on any single outside source of assistance. But in order to become increasingly self-reliant in financial terms, Papua New Guinea must develop substantial new sources of revenue. In the past, 
the primary emphasis has been on taxation of the expatriate sector of the economy-taxes on the high incomes of expatriates and on the earnings of companies that in large part served the needs of expatriates. But this system of taxation cannot continue to provide for our budget needs

Some expatriates, and some of the businesses that serve them, will be leaving as the Public Service and, hopefully, the private sector as well become increasingly staffed by Papua New Guincans. In any case, the Government's needs for increasing revenue-for social programs, for industrial development, and especially for rural development projects to improve the quality of life in the villages-will require an expansion of the tax base beyond its present narrow limits. Some additional money might be raised by a tax on agricultural production, and there is certainly a good case to be made for increasing the present low rates of company tax and personal income tax, at least for those in the higher income brackets. But to produce substantial new revenue we need large-scale industrial projects, and mining offers a major opportunity for such projects. Provided that mining laws and agreements give the Government an adequate share of the profits from such projects, they would appear to be desirable.

Mining projects can also be a source of employment and can stimulate development in other areas of the economy. For example, the workers in a mining project require food, and the presence of a mine can stimulate a great deal of agricultural development to supply this need. Similarly, the presence of a mine and its workforce creates a demand for a variety of service industries and for industrial supplies. To the extent that these demands can be met from within the country, the mine serves as a stimulus for economic development. And, if the output of the mine can be used in further industrial processes-for example, in the case of copper, by smelting, refining, and producing fabricated copper items--this will serve as a powerful force for rapid and extensive industrial progress. Unfortunately, these potential benefits are not always realised. Employment in mining tends to be relatively low, in relation to the total amount of investment. And mining projects do not always stimulate further industrial development as much as they might. Often all supplies are imported from other countries, and little or no processing takes place before the ore is exported. 
Another potential beneft of going forward with mining projects is more specifically related to the situation in Papua New Guinea today. There has been some concern expressed that our Government is not sympathetic enough to business interests, and some fear that this supposed hostility will frighten away potential investors and thereby deprive the country of the possibility of industrial development. I believe that the attitude expressed by the Government to date has been entirely proper. It is, as I understand it, an attitude of caution with respect to investment, of making sure that investment projects contribute as much to Papua New Guinea and its people as they do to the finances of the foreign companies involved. I see no reason why such an attitude-which has been adopted by many other countries around the world including, in recent months, Australia-should frighten serious investors. But the fact remains that there is substantial pressure, both from within the Government and from the business community, for the Government to demonstrate its good faith by agreeing to additional investment projects. If a new mining project can be negotiated on mutually satisfactory terms, it might relieve some of the current worries.

On the other hand, there are significant reasons why a country in Papua New Guinea's position might be wise to hold back, and put off mining projects for at least some years. First of all, there is the question of what a major mining operation does to the people. Instead of a self-reliant society, in which people worked effectively together in family groups, a mine can create a society where thousands of dependent individuals all look to the big company for all their needs. Subservience is the antithesis of self-reliance. It is true that the mining company, and the highly paid individuals who work for it, may give some of their money as charity to others who are less well off. But charity is not justice. And giving a few dollars to a famine appeal is not the same as sharing equally the hardships and problems of life.

In addition to these general implications, there is the direct impact upon those people who live in the mine area and upon the structure of their society. At the Fifth Waigani Seminar Eugene Ogan and I delivered a paper documenting some of these effects on the Nasioi people of central Bougainville (Momis and Ogan 1972). Mining in this area has created sharp antagonism between the people, who 
regarded the land as theirs, and the Government, which, under the law, possessed claim to the minerals under the surface. Mining has provided some employment for the Nasioi, but at the same time it has had serious social effects. For example, school enrolment has declined, either because young people leave school to seek employment in the towns or because older village leaders increasingly reject education as part of the white man's system of exploitation. Alcoholism has become a serious problem, and traditional systems of social control are being destroyed without any suitable alternative being offered in their place. Nasioi society is no longer the stable, satisfying society that it once was, and mining must bear part of the blame.

Then there is the question of conservation and the environment. Mining can have disastrous effects on a region. In a copper mining operation, tailings from the ore concentrating plant kill the fish in the rivers and destroy vegetation in the valleys. This is already happening on Bougainville. The constructions associated with a mine result in ripping up hundreds of acres of trees and garden land and replacing it with sterile concrete or simply with a huge hole in the ground. In the case of smelting operations, the gases that escape from a smelter may poison people's lungs and kill off vegetation for miles around. Unless very careful controls are exercised, mining poses a real danger to the environment.

A third reason for holding off on the development of mining projects turns on the question of control. At its present stage of development, Papua New Guinea does not have the financial resources to hold a majority interest in mining projects, nor does it have the supply of trained engineers, geologists, and administrative personnel who could run such projects. One might well argue that it would be in this country's long-term interest to wait until it has the money and the expertise so that Papua New Guinean citizens can play an active role in directing mining activities. It would also mean, however, that it would very likely be twenty years or more before any major mining projects went forward; it seems likely to be at least as long as that before there are enough trained and experienced Papua New Guineans to control the mining industry effectively.

These arguments for and against going ahead with mining projects must be carefully considered. If we do choose to go ahead with such 
prujects, we must do so in a way that minimises the undesirable effects to which I have already referred.

My own feeling is that the needs of Papua New Guinea for government revenue and for industrial development are sufficiently pressing for us to go forward where possible with mining projects. But we must do so carefully; we must make sure that mining projects serve the national interest and that the rights and values of people affected by the projects are protected.

I believe that one way of assuring this would be to require that agreements for mining projects adhere to the terms proposed by the Papua New Guinea House of Assembly in its resolution on mining policy passed November 1972. The terms of that resolution-which was approved with no more than a handful of dissenting votes-are as follows:

1. The equity of Papua New Guineans in any major mining venture should be as great as possible and should normally constitute a majority holding;

2. Such equity should normally be held by the Government or a government instrumentality;

3. The terms of any mining venture should provide:

(a) for the maximum employment of Papua New Guineans;

(b) that the venture should, as far as possible, be labourintensive rather than capital-intensive;

(c) for maximum employee-management communication and, as far as possible, employee participation in decision-making; and

(d) for the development of secondary and tertiary industry in connection with the mining venture, including the maximum feasible processing of ore prior to export;

4. Any corporation in a mining venture should be obliged to train or arrange for the training of Papua New Guineans to take over managerial and technical positions in accordance with a definite timetable established for each venture;

5. In the setting up and conduct of any mining venture, maximum use should be made of goods and services produced from 
resources from within Papua New Guinea and provided by Papua New Guineans;

6. Any ancillary economic activity generated within Papua New Guinea by a mining venture should be conducted as far as possible by Papua New Guineans;

7. The terms of any mining venture should aim to preserve social harmony in the area of operations and to maintain and repair the physical environment;

8. In negotiating the terms of any mining venture, the Government should seek to obtain the maximum collateral advantages in terms of trade and assistance for development;

9. An agreement setting up a mining venture should include formulae agreed to by both parties which provide for changing circumstances such as price fluctuations, variations in profitability, and the development of new technology;

10. To the maximum extent, government purchases of equity in mining ventures should be paid for out of future earnings of the mine instead of large initial cash outlays and commercial loans;

11. Any agreement for a mining venture should provide at least as much revenue for the Papua New Guinea Government-taking into account any costs that must be borne by the Governmentas is provided on the average by similar ventures in other developing countries;

12. Mining agreements should provide that disputes between mining companies and the Government will be settled in accordance with Papua New Guinea legal procedures and not by resort to outside arbitrators; and

13. The offering of tax holidays and other investment incentives should be balanced against the nation's need for revenue and equitable treatment of all industry, both foreign owned and Papua New Guinean.

As I have indicated, I believe that a system of laws and agreements for mining projects based on a set of principles like this would provide a reasonable balance between the benefits of mining and the need to 
guard against mining's undesirable effects; and I will now consider the Bougainville Agreement in this light.

The basic terms of the Bougainville Copper Agreement are familiar by now. Briefly, the Agreement, signed by the Papua New Guinea Admintsartion and Bougainville Copper Pty Ltd (part of the worldwide Rio Tinto Zinc mining group) in 1967, provides for the following:

1. a 20 per cent government equity in the project, which the Government has purchased at a cost of $\$ 26$ million, using loan funds from the Australian Government for the purchase;

2. a 42-year mining lease over the Panguna mine site;

3. taxation provisions for a three-year tax holiday after the start of production, to be followed by a period estimated at four to five additional years in which the company will pay no tax because of accelerated depreciation provisions;

4. taxation at an overall rate of approximately 50 per cent following the tax holiday and depreciation period;

5. a royalty of 1.25 per cent on the value of the concentrate exported ( 5 per cent of this royalty-about six cents out of every hundred dollars in sales-goes to local landowners);

6. a major part of the project's infrastructure, including schools, hospital facilities, communications, etc. to be provided by the Government. The capital costs for the infrastructure are currently estimated to total some $\$ 34.8$ million. The annual operating cost of government services is $\$ 3.2$ million.

The copper mine on Bougainville accounts for nearly 30 per cent of the total Papua New Guinea economy; it accounts for 60 per cent of our exports. Yet the Government will receive only a minimal financial return from the project through the rest of this decade. The following figures, which are taken from a consultant's report on the project prepared for Bougainville Copper, give a rough idea of the enormous profits to be made: in $1972-3$, estimated total profit is $\$ 75$ million, of which the Government will receive $\$ 8$ million-or 11 per cent-in dividends, royalty, and dividend withholding tax; in 1973-4, estimated total profit is $\$ 85$ million, of which the Government would receive 
$\$ 11$ million or 13 per cent; in $1974-5$, estimated total profit is $\$ 88$ million, of which the Government would receive $\$ 15$ million, or 17 per cent.

In fact, it now seems clear that these estimates, which were made in January 1973, substantially understate the amount of profits. Since that time, there has been a sharp increase in the world market price for coppet and the company has negotiated additional sales contracts that will raise its output to 190,000 tons of copper a year, well above earlier predictions. On the basis of these new developments, it can be reasonably forecast that annual profits will certainly be at or above $\$ 100$ million per year.

In view of these enormous profits, it is clearly justifiable for the Papua New Guinea Government to seek a larger share of the money generated by the Bougainville mine for the use of this country's people. I would like now to suggest some ways in which the general principles contained in the House of Assembly resolution on mining policy could be applied to the Bougainville operation, through a re-negotiation of the 1967 Agreement.

First, there is the question of taxation. In most other developingcountry copper producers, the host government receives between 40 and 50 per cent of profits. Such a rate should be in effect now-not in 1979 or 1980 . If reasonable tax rates were imposed beginning in $1972-3$, the Government would be receiving an additional $\$ 40$ million per year. This would go a long way toward achieving the important social aims of our new development program.

Second, there is the question of equity. The House of Assembly resolution calls for a majority equity to be held by the Government in most cases. While I do not regard actual ownership of equity as crucial to ensuring that a mining project benefits the country-taxes and means of assuring linkages with the rest of the economy are far more significant-I do think that it would be reasonable to work out a formula under which an increasing share of the ownership of Bougainville Copper would pass into Papua New Guinean hands over a period of time. This could easily be done while still ensuring that the company received a substantial return on its investment. I think it would be entirely possible to devise a formula under which 51 per cent owner- 
ship in the project would be transferred to Papua New Guinea within fifteen years.

Third, there is the question of localising the work force, especially in technical and professional jobs. The 1967 Agreement contains no definite timetable for localisation. The company currently estimates that 90 per cent of the work force will be Papua New Guinean by 1980 , but their own consultants estimate that only 80 per cent of the workers will be local people. I suggest that a re-negotiation include a specific timetable for localisation of at least 90 per cent by 1980 , with commitments by the company to send Papua New Guineans abroad for technical training if such training is not available locally.

Fourth, there is the area of processing of ore. It is clear from the example of other countries that Papua New Guinea already produces more than enough copper to make a smelting, refining, and perhaps even fabricating operation technically feasible and very likely economically profitable. A re-negotiation of the Agreement should include definite provisions for feasibility studies and financing of a processing complex within Papua New Guinea, so that we could obtain additional income and employment opportunities.

Fifth, the existing mining operation has clearly not maintained social harmony nor has it repaired and preserved the physical environment. A re-negotiated agreement should contain specific conservation provisions. In addition, the re-negotiation process must include participation by the local people who have been affected by mining activities, so that their unresolved grievances can finally be settled.

Sixth, there should be careful consideration given to increased local purchasing, and even to using some of the mine earnings to fnance plants for production of supplies needed in mining, if this can be done economically. In this way, the mine can be made to serve as a major point of growth for the economy as a whole-not just an isolated enterprise.

These are only some of the major points that should, I believe, be dealt with in a re-negotiation of the Bougainville Copper Agreement. There are other issues, such as the labour-management relations and the company's activity in promoting retail business, that perhaps need to be looked at to see if changes are necessary, but a re-negotiation that dealt fairly with the six points I have mentioned would resolve most 
of the outstanding issues connected with the Bougainville project and would give Papua New Guineans an agreement they could be proud of.

It would also be in the long-term interests of the company to agree to a re-negotiation. No company can maintain its position when the balance is so unfairly tilted in its favour. Sooner or later, there will be a strong popular movement demanding changes in the operation of the mine, and the longer the company waits, the less it will be left with, as the experience of Kennecott and Anaconda in Chile demonstrates. If action is taken now-before the company has shipped its fantastic tax-holiday profits out of the country-it will be possible to work out an agreement that everyone can live with. If re-negotiation is left till later on, there will unquestionably be more bitterness, more mutual distrust, and perhaps even violence. 


\title{
22 The triumph of colonialism
}

\author{
P. G. Sack
}

It may be possible to give an adequate account of the history of Western countries over hundreds of years without ever mentioning land. Not so for Papua New Guinea, where land is history and history is land, where land disputes frequently develop into contests of historical knowledge and where the country's very topography is a historical map; where culture heroes turned into islands and tears into creeks and where each conspicuous rock or tree stands for a historical or mythological event. The land and the people, as well as plants, animals and spirits, are all bound together by a continual and continuing process of metamorphosis. In the midst of all this change land is the only thing that remains permanent. Land, underneath its changing surface, is eternal. It is the beginning and the end of history, it is not only beyond man but also beyond creation.

To say that land in Papua New Guinea owns the people, instead of the people owning the land, is almost true. Traditionally man is clearly not the master of the land-it is too important for that-but neither is he its serf. In order to make land his own, man has to court it in many ways. But no mortal individual can establish a (potentially) permanent relationship with land. This can only be done by an (ideally) immortal group as a result of a process of identification. This process is also necessary to give the group its own identity. A traditional group is a union of people with land, and the links between the group and the land may be more important than the ties among its members.

The attitude to land which has prevailed in Western countries for many centuries was somehow reversed in traditional Papua New Guinea. Instead of land named after the group controlling it, groups took the name of the land on which they were 'born'. Instead of people, by occupation, turning land into a political territory, the identification with land turned people into a political group. For this reason it was the composition of the group rather than the size of its territory which changed according to the varying population pressures. The absorption of outsiders into the group was the traditional alternative 
to the conquest of foreign territory. This was the root for the strength as well as the weakness of the traditional socio-political systems in Papua New Guinea. It prevented large-scale wars but also the development of large-scale political units. The people of Papua New Guinea could not obtain King's Peace but they also did not have to fight a king's battles. Balance was achieved at the expense of growth.

The traditional attitude to land is the common denominator behind the different forms of socio-political organisation and at the same time the key for understanding any of the many traditional cultures. This attitude made it impossible for the people to own land or for their leaders to assume territorial sovereignty. It did not allow them to believe in an almighty creator God or to administer objective justice but, at the same time, saved them from having religious wars, concentration camps, or a landless proletariat. Talking about land in the traditional Papua New Guinea context thus means a great deal more than talking about land in Western countries. And the difference is not merely a matter of land as living space versus land as a commodity, or rational exploitation of natural resources versus a magical co-operation between a gardener and his garden; it involves people - in Papua New Guinea as well as in the West-in their totality: it shapes their entire outlook on life.

All this may seem to imply that the people of Papua New Guinea have lived on their respective land since time immemorial, deeply rooted in its soil, surrounded by closely defined boundaries, jealously guarding its economic potential. Nothing could be further from the truth, although it partly corresponds with the view of history as transmitted by oral tradition. But then it is the aim of oral tradition to maintain the illusion of stability in the face of change, to show that things have always been the way they are in order to reconcile facts with the ideal. Oral tradition succeeds to the extent that history is only as long as human memory. But looking more closely at the short span of a few generations separating the present from the beginning of time, one is struck by the amount of movement rather than by the lack of it.

In many parts of Papua New Guinea very few people indeed died at the place of their birth. In the more densely populated areas, in particular, groups pushed each other constantly off their lands and everywhere villages were voluntarily abandoned for a variety of 
natural and supernatural reasons. It was also common for groups to split and to form new settlements. Movement, however, was not merely the result of such accidents; it was part of the system, especially in thinly populated areas. According to the rules of residence and unilineal descent, half of the people had to leave the place of their birth and, more importantly, had to use land identified with another group during their married life. The periodical shifting of gardens and substantial fallow periods worked against the development of a close attachment to specific plots of land used for food production. And, with few exceptions, the people had a lot more land than they needed to fulfil their needs. Economic jealousy over land played no significant part in traditional life. This further increased the mobility of individuals and groups across the lines of kinship and territorial 'boundaries'. It also meant that land boundaries in the sense of economic divisions hardly existed. Boundaries were defined only in so far as this was necessary for political reasons. It is not the boundary concept in the Western sense which figures prominently in traditional thinking but a similar yet quite different notion. Whereas Westeners see the surface of the earth as one whole which man can divide by means of artificial boundaries into separate political or economic units, the people of Papua New Guinea see it as composed of an indefinite number of distinct land units, defined by natural boundaries, which exist independent of men. The traditional view is in fact diametrically opposed to the boundary concept in the Western sense: it denies that man can divide land into little boxes which he can own like a thing.

Land in traditional Papua New Guinea therefore meant not only much more but at the same time much less than in modern Western societies. This paradox also explains what seems to be a vast discrepancy between traditional theory and practice: one balances the other-the enormous amount of movement and flexibility in fact had to be counteracted by an equally strong ideological stress on continuity and strict principles. The balance was precarious but it survived, at least until a hundred years ago, when European settlement began.

To appreciate the significance of this event for the history of Papua New Guinea, it is first of all necessary to keep in mind that the European settlers were not the first and only wave of migrants coming to this country. When they arrived, Papua New Guineans looked back 
on 50,000 years of external and internal migration. The arrival of foreigners, speaking another language, following strange customs, and wanting land was not beyond the scope of their experience, and they had their own ways of dealing with such a situation, ranging from adoption to digestion. But, in a way, this made things more difficult. To adjust to an entirely new situation is hard, and may sometimes prove impossible, but the problems are at least visible. The tensions caused by misunderstandings as a result of wrong assumptions and expectations can be far more serious; they can permanently poison a relationship. The goodwill which may have existed in the beginning on both sides soon disappears and only the bitter taste of apparent dishonesty remains: our forefathers have been tricked by the whites-who in turn believed that all natives were habitual liars.

Yet the importance of these misunderstandings should not be overestimated. After all they were but the result of real cultural differences. Moreover, many of the problems which developed are inherent in any form of colonialism, whether cross-cultural of not. Nevertheless, in the long run the problems caused by the clash of cultures will prove to be the most significant for the history of Papua New Guinea. In a few short decades the colonial era will be a mere episode in its past, but the culture clash will continue. In many ways it has only just begun. And the outcome of this clash rather than any real or imagined colonial legacies will shape the country's future.

From this point of view the differences between the various colonial administrations in Papua and New Guinea until their administrative unification after World War II are negligible. In any case these differences have in the past been somewhat exaggerated. They were differences not so much in basic political aims but rather in the degree of success with which these policies were implemented, or they were a matter of individual personality.

The current popular view of Papua New Guinea's colonial history is almost as loaded with myths as its pre-colonial oral tradition. But whereas traditional mythology is based on an honest non-scientific approach, the modern myths are frequently the result of an irresponsibly sloppy presentation of what are alleged to be historical facts. The widespread belief that Bougainville and Buka were handed over by Britain to Germany in 1899 , for instance, has no more to do with 
facts than the belief that New Guinea is the spine of a Wogeo culture hero. ${ }^{1}$ Moreover, the latter belief makes at least sense in its own terms - the former is just a plain untruth. On the other hand, both beliefs are politically motivated or can be used for political ends, and the present period of decolonisation is particularly prone to replace history with propaganda.

When Papua and New Guinea came under European rule in the 1880 s the established principle of Western colonial law that all land in a colony inhabited by 'primitive' people became automatically the property of the colonising state or sovereign, had fallen into disfavour. Proclaiming the British Protectorate over Papua, Commander Erskine solemnly assured the people 'your lands will be secured to you'. The Germans were more cautious, but the Imperial Charter granted to the Neu Guinea Kompagnie also leaves no doubt that native land rights were to be respected. But the idea of European economic domination had not been abandoned. According to Sir William McGregor, Papua's first Administrator after the assumption of full sovereignty, it was the task of government to 'prepare the country for development by Europeans. There is not, and there has not been, any other policy' (quoted in Crocombe and Hide 1971: 309).

What protected the people far more effectively than the good intentions of their new colonial masters was the climate of their country. Papua New Guinea was just not suitable for large-scale European settlement. To push the people farther and farther into the interior, taking over all their land, simply did not make economic sense-unless they were at the same time replaced by another, imported, coloured population, which could only be a last resort, if it proved impossible 'to teach the natives how to work.' Leaving mining out of account, which belongs in a rather special category, ${ }^{2}$ there was no choice but to develop Papua New Guinea into an exporter of tropical crops, either on the

1 What in fact happened in 1899 was just the opposite: Britain acquired a larget slice of the Solomons at the expense of Germany--as 'compensation' for waiving all claims to Samoa in her favour. Germany handed over the Shortlands, Choiseul and Isabel which, in addition to Bougainville and Buka, had been part of German New Guinea since 1886.

2 Small-scale mining resembles hunting and gathering, whereas the effects of large-scale mining are those of industrialisation and urbanisation. 
basis of European-owned plantations, worked by large numbers of indigenous wage labourers, or of small-scale indigenous cash-cropping, the export being handled by European traders. (In both cases the people were, of course, expected to spend their income on imported European goods.)

Papua New Guinea began its colonial history as a trading colony. But the first plantations were soon established. Although it took many years before plantation exports outstripped those obtained by trade, the European settlers agreed that it was both economically and socially preferable to be a planter rather than a trader. The Administration, on the other hand, tended, for a number of reasons, to encourage indigenous cash-cropping, even at the expense of the development of European plantations. However, the freedom of action was fairly limited, since the European planters were a vital revenue-producing factor. Still, especially in New Guinea, considerable tensions developed between the Administration and the settlers on this score.

These tensions were not due to a shortage of land; there was sufficient land to develop indigenous cash-cropping and European plantations side by side. The problem was originally a shortage of people to work the available land, and this problem was seen in a very serious light because the Europeans believed until well into this century that the people of Papua New Guinea were slowly but surely moving towards extinction. The planters feared that wage labour would prove an unattractive alternative to Papua New Guineans as soon as they were given and had learned to appreciate the opportunity of earning cash by growing their own commercial crops. In most parts of the country, however, it took a long time before this appreciation developed. Until then the Administration had even greater difficulties with its cash-cropping projects than the planters had with recruiting labourers.

Seen from an economic point of view, land should have caused no problems during the colonial history of Papua New Guinea. Only about 3 per cent of the land was alienated to Europeans, and although this is among the most fertile land and much of the rest may be useless for economic purposes, there are many hundreds of thousands of acres which could be made equally productive.

Looking at particular areas instead of the country as a whole, the 
picture begins to change-but not decisively. Even among the Tolai, on New Britain's Gazelle Peninsula, where alienation figures are ten times the national average, the people kept more land than was required to fulfil the subsistence needs of the population which existed when large-scale alienation ceased. What causes the present land shortage in the Tolai area is not land alienation to Europeans in the dim colonial past but a drastic increase in the number of people and their eagerness to plant cash crops over the last twenty years. In other words, land shortage is due to an increase in indigenous land demands rather than to a reduction in land 'supplies' by alienation to Europeans.

But this picture is still too general. First of all land never was equally distributed among the various Tolai groups, and alienation was also heavier in some parts than in others. There are groups of Tolai who even now have more land than they can utilise. There are others whose traditional land holdings are-irrespective of alienation -inadequate for present needs. And there are groups who have lost most or even all their land through alienation. Some of these 'landless' groups became only recently fully aware of their situation. Past alienations had left them without land of their own but not without land they could use. They either continued to use sections of their land although it was legally alienated or they moved to relatives or into formal or informal reserves, where for a long time no one bothered to work out the legal position of the people concerned or to inform them about it. The traditional lack of economic jealousy in land matters has so far prevented the alienation of land creating a landless proletariat. A change in this attitude will soon alter this.

This finally taises the decisive point: the importance of land for Papua New Guinea's colonial history cannot be grasped if a purely or predominantly economic view is adopted. What caused the problems was not economic rivalry but a clash of cultures. The basic problem was not who should own the land but whether or not land could or should be owned in the Western sense. It was primarily a fight between different attitudes to land and not a fight over the economic potential of land between parties who intended to use it in very much the same way.

In Papua New Guinea this clash of attitudes was particularly marked because the Western views took an extreme form. In a plantation colony land is of prime importance. Land is not only an important 
source of income but the basis of the planters' ideology. Landed property is the foundation of status in the European community, and the larger the holdings (not the more efficient the management) the higher it tends to be. At the same time the planter sees his alleged ability to utilise land in an efficient way and the alleged inability of the indigenous population to do so as the main justification for his role within the colony. The 'idleness of the land' even more than the 'people's laziness' serves as an alibi for colonial exploitation.

Despite the importance of land as a source of wealth and status, the emotional links between a planter and his land are weak. First of all, permanent tree-crops reduce the contact with the soil to a minimum. Second, a planter does not work the land himself but has his labour line. He is rarely directly concerned with his land; his main worries are the performance of his labour line, pests attacking his trees, and the price he can obtain for his crops. Moreover, most planters in Papua New Guinea did not intend to make their plantations their permanent home. They came to make money and wanted to leave as soon as this goal was achieved. Further, many plantations were run by large anonymous companies. In short, the colonial attitude to land in Papua New Guinea was diametrically opposed to the traditional attitude of the people: for the colonists land had maximal economic importance but was emotionally irrelevant; in the lives of the people land played an emotional key role but the need to monopolise its exploitation was minimal.

Yet it would be wrong to see the people of Papua New Guinea as solitary dreamers without interest in material things. Many of them were in their own way as business-minded as the European settlers. They were as much inclined as their colonial masters to see the culture gap separating them almost exclusively in material terms. Such an extreme materialistic outlook has its own magic. The step from tradiditional to colonial cargo cults is easy. It usually takes only a little twist to change directions, and for a long time it may seem possible to combine European cargo with Melanesian values without modifying either. This makes it so important to stress again and again the essentially materialistic nature of Western colonialism. It reduced world history to a race between the 'haves' and the 'have-nots'.

This materialistic approach gave colonialism its strength. Instead of 
forcing an alien culture on people it merely made them buy its outer shell. Steel axes are so much more persuasive than Shakespeare and it is so much easier to motivate someone to learn to drive a truck than to play Bach on the violin. The curse of Western colonialism is that it turned natives into colonialists, into strangers in their own land. Instead of colonising, it colonialised them, so much so that even the doom and glory of decolonisation is today traded as a second-hand merchandise among emerging nations.

It merely seems that white colonialists alienated the black man's land. In truth they alienated him from his land. The land is still there and it is economically far more valuable than ever before. But it is no longer the same land because the people see it through different eyes. It is now divided into smaller or larger boxes which must be owned because they are property. The battle-cry of the stolen land signifies the triumph and not the failure of colonialism. Thereafter land tenure conversion and resettlement schemes are very logical steps. The process of conversion is almost completed. The colonialists will stay; they merely change colours. It is the ancestors who will have to go into exile.

What will their descendants achieve? The more the culture gap narrows the faster the poverty gap widens. The golden carrot which was to be the converts' reward moves further and further away. Yet this is not decisive; the rules of the race could be changed to adjust the comparative speed of the 'haves' and the 'have-nots'. But the golden carrot may have a rotten core. Even those Europeans who are still convinced that tribal fighting is primitive savagery, whereas they see the far higher death toll on their own roads as an unfortunate but reasonable price for a civilised mode of transport, are getting worried about pollution and limited energy resources. It is possible that they want to stop the race. Their pleading, however, will not sound too convincing in the ears of those who are asked to sacrifice the golden calf before they have had the chance to enjoy it. It will merely sound like a new and rather desperate trick. This is the irony of colonialism: it may succeed in persuading the people of Papua New Guinea that their land consists of little property boxes which they have the duty to exploit as efficiently as possible-just when their former colonial masters begin to re-learn that land is living space which must be protected. 


\section{References}

Abrams, C. 1953. 'Utban Land Tenure Problems and Policies'. Housing and Country Planning Bulletin No. 7. U.N., New York.

Alland, A. 1972. The Human Imperative. New York.

Ardrey, R. 1966. The Territorial Imperative. New York.

Berrill, P. M. 1968. 'Nive Land Tenure and Survey'. Proceedings of the New Zealand Institute of Surveyors' Conference. Christchurch.

Brodrick, G. C. 1881. English Land and English Landlords. London.

Brookfield, H. C. and Brown, P. 1963. Struggle For Land: Agriculture and Group Territories among the Chimbu of the New Guinea Highlands. Melbourne.

Brown, P. 1972. The Cbimbu: A Study of Cbange in the New Guinea High. lands. Cambridge, Massachusetts.

Clayton, E. S. 1964. Agrarian Development in Peasant Economies: Some Lessons from Kenya. Oxford.

- 1970. 'Agrarian Reform, Agricultural Planning and Employment in Kenya'. International Labour Review, 102: 431.53.

Criper, C. 1967. The Politics of Exchange: A Study of Ceremonial Exchange in the New Guinea Higblands. Cambricge, Massachusetts.

Crocombe, R. G. 1964. Land Tenure in the Cook Islands. Melbourne.

- 1971a. 'Land Reform'. In R. G. Crocombe (ed.), Land Tenure in the Pacific, 375-400. Melbourne.

-, 1971b. 'The Cook, Niue and Tokelau Islands'. In R. G. Crocombe (ed.), Land Tenure in the Pacifu, 60-90. Melbourne.

-..-, (ed.), 1971c. Land Tenure in the Pacific. Melbourne.

- and Hide, R. 1971. 'New Guinea: Unity in Diversity'. In R. G. Crocombe (ed.), Land Tenure in the Pacific, 292-333. Melbourne.

Duffy, F. G. and Eagleson, J. G. 1895. The Transfer of Land Act 1890. Melbourne.

Dumont, R. 1973. 'Notes From the Roadside'. In R. J. May (ed.), Priorities in Melanesian Development. Canberra.

Epstein, A. L. 1969. Matupit: Land, Politics and Change among the Tolai of New Britain. Canberra.

Espie, F. F. 1973. 'Bougainville Copper: Difficult Development Decisions'. In R. J. May (ed.), Priorities in Melanesian Development. Canberra.

Fenbury, D. M. 1971. 'The Confusion of Cultures'. New Guinea, 6: 39-42. Fleming, T. J. 1968. An Analysis and Review of the Kenya Land Reform Programme 1966-1968. Unpublished.

-, 1971. 'Land Problems in Developing Countries'. Australian External Territories, 11(1): 27-35.

Glasse, R. M. 1965. 'The Huli of the Southern Highlands'. In P. Lawrence and M. J. Meggitt (eds.), Gods Gbosts and Men in Melanesia. Melbourne. 
Goava, S. 1973. Address to the Seventh Waigani Seminar. Unpublished.

Granger, K. J. 1971. 'Population and Land in the Gazelle Peninsula'. New Guinea Research Bulletin, 42: 108-21.

Groves, M. 1963. 'Western Motu Descent Groups'. Etbrology, 2(1): 15-30.

Hall, E. T. 1963. 'Proxemics-A Study of Man's Spatial Relationship'. In I. Galdston (ed.), Man's Inage in Medicine and Antbropology, 422.5. New York.

Hide, R. 1973. "The Land Titles Commission in the Chimbu: An Analysis of Colonial Land Law and Practice, 1933-1968. New Guinea Researcb Bulletin, 50.

Hirschman, A. O. 1963. Journeys Towards Progress. 20th Century Fund, New York.

Hogbin, H. I. 1939. 'Native Land 'Tenure in New Guinea'. Oreania, 10: 135-65.

Hookey, J. 1973. The Contribution of the Supreme Court to the Recognition of Customary Rights in Land. Paper delivered at the Seventh Waigani Seminar. Unpublished.

Hsu, F. L. K. 1973. 'Prejudice and its Intellectual Effect in American Anthropology'. American Antbropologist, 75: 1-19.

Jowitt, W. A. J. 1959. The Dictionary of English Law. London.

Julius, C. 1962. Customary Land Rights in Papua New Guinea. Unpublished.

Kinyanjui, J. K. 1971. 'Land Reform in Kenya'. New Guinea Research Bulletin, 40: $125-36$.

Lawrance, J. C. D. 1966. Report of the Mission on Land Consolidation and Registration in Kenya 1965-1966. Naitobi.

Lynch, C. J. 1969. 'A Description of Aspects of Political and Constitutional Developments and Allied Topics'. In B. J. Brown (ed.), Fasbion of Law in New Guinea. Sydney.

McEwen, J. M. 1968. Report on Land Tenure in Niue. Wellington.

Maunsell \& Partners \& Voorhees, A. M. 1970. Pont Moresby Development Study. Melbourne.

Momis, J. and Ogan, E. 1972. 'A View from Bougainville'. In M. W. Ward (ed.), Change and Development in Rural Melanesia. Canberra.

Morawetz, D. 1967. 'Land Tenure Conversion in the Northern District of Papua'. New Guinea Researcb Bulletin, 17.

Papua New Guinea. 1971a. Population Census-July 1971. Preliminary Bulletin No. 1. Urban Centres. Bureau of Statistics, Konedobu.

- 1971b. The Development Programme Reviewed. Office of Programming and Co-ordination, Port Moresby.

- 1973a. Report of the Committee Investigating Tribal Fighting in the Higblands. Port Moresby.

_- , 1973b. Development Programme: Review of Progress 1971-1972. Office of Programming and Co-ordination, Port Moresby.

Parker, M. L. 1971. 'Agriculture in the Development of Papua and New Guinea'. Australian Journal of Agricultural Economics, August: 82-94.

- 1973. The Papua New Guinea Economy, 1978. Unpublished. 
Polansky, E. A. 1966. 'Rabaul'. Soutb Pacific Bulletin, 16(2): 42-7.

Pollock, F. and Maitland, F. W. 1952. The History of Englisb Law. 2nd ed., Cambridge.

Public Accounts Committee. 1971a. Twenty-ninth Report. The Department of Lands, Surveys and Mines. Mimeo, House of Assembly, Port Moresby.

Read, K. E. 1953. Notes on the Asaro, Jameguka and Laruepe Peoples of the Goroka Sub-District. Unpublished.

—, 1954. 'Marriage among the Gahuku-Gama'. Soutb Pacific, 7: 864-71.

Rofe, R. G. 1965. 'Urbanisation-Lae, Territory of Papua and New Guinea'. Soutb Pacific Bulletin, 15(3): 22-5, 63.

Rowton Simpson, S. 1969. Security of Tenure and Proof of Title. Paper delivered at the Third Waigani Seminar. Unpublished.

—, 1971. 'Land Problems in Papua-New Guinea'. New Guinea Research Bulletin, 40: 1-29.

Ruoff, T. 1961. 'Links with London'. Australian Law Journal, 34: 358-60.

Sack, P. G. 1971. Traditional Land Tenure and Early European Land Acquisitions. Ph.D. thesis, Australian National University.

- 1973. Land Between Two Laws: Early European Land Acquisitions in New Guinea. Canberra.

Salisbuty, R. F. 1970. Vunamami: Economic Transformation in a Traditional Society. California.

Sanders, D. 1973. Compensation Schemes for Native Land Claims. Paper delivered at the Seventh Waigani Seminar. Unpublished.

Smith, S. S. and Salisbury, R. F. 1961. Notes on Tolat Land Law and Custom. Kokopo.

Sorrenson, M. P. K. 1967. Land Reform in Kikuyu Country. Nairobi.

Standish, W. A. 1973a. Warfare, Law and Leadership in the Highlands. Paper delivered at the Seventh Waigani Seminar. Unpublished.

-_, 1973b. 'Papua New Guinea Review'. Australian Quarterly, March: 107-21.

Swynnerton, R. J. M. 1954. Plan to Intensify the Development of African Agriculture in Kenya. Nairobi.

Taylor, D. R. F, 1969. 'Agricultural Change in Kikuyuland'. In M. F. Thomas and G. W. Whittington (eds.), Environment and Land Use in Africa. London.

Taylor, R. D. \& Partners. 1971. Lae Urban Development Study. Port Moresby. - 1972. Madang Urban Study. Port Moresby.

Totrens, R. R. 1857. Election speech supporting R. B. Andrews, reported in the Soutb Australian Register, 1 June 1857.

- 1859 . The South Australian System of Conveyancing by Registration of Title. Adelaide.

University of Papua New Guinea. 1973. Alotau, Milne Bay District-a New Town in Papua New Guinea. Department of Geography Occasional Paper No. 7. 
Ward, A. 1972. 'Agrarian Revolution: Handle with Care'. New Guinea, 6(1): 25-34.

Ward, R. G. 1969. Inaugutal Lecture. Bulletin of the Geograpbical Society of New South Wales, 1(2): 9-16.

- 1971. 'Internal Migration and Urbanisation in Papua New Guinea: Population Growth and Socio-economic Change'. New Guined Research Bulletin, 42: 81-107.

Willis, I. 1972. 'Lae's Land Grabbers. White Man's Justice-but who can afford it?' New Guinea, 6(4): 4.

Winders, J. R. 1957. Report on an Investigation into the Desirability and Practicability of the Introduction of Local Government into the Territory of Papua and New Guinea 1956. Port Moresby. 


\section{Index *}

Unless otherwise specified, the general subject-headings refer to conditions in Papua New Guinea.

absentees: in Kenya, 64, 67; in Niue, 83

Acts, see Statutes, Ordinances and Bills

adjudication, 13, 72, 73; in Kenya, $64-5,66-8$; in Niue, 77-81; Land Adjudication Commissions, 138-9, 156; see also consolidation, disputes, registration

Administration, 1-4, 115-16; and indigenous land rights, 43, 149; and land alienation, 9, 43, 159-69, 1712, 203-8, 181-9; and Land Bills $1971,1-3,11-12,46-7,60-1$; and mining, 181-99; and urban development, 173-6; indigenous attitudes to, 159-63, 181-9; see also Australia: (Federal) Government, District Administration, kiaps, National Coalition Government

Administration land, return to indi. genes, 14-15, 168, 171

agriculture, traditional methods of, $19,34,54-9$

agricultural development, 13-14, 16 $31,49-60,73,116-20,134,204-5$; see also cash cropping, economic development, land: future demand for, subsistence agriculture, Swynnetton Plan

alienation of land to Europeans, 8$10,13-14,143,144,159-60,171-2$,
$181-9,208$; and national identity, 165-6, 168; compensation for, 9, $144,159,167,176$; indigenous attitudes to, 9, 43-4, 88-90, 171; possible approaches to the problem, $89,150-63,165$; psychological factors, 33-9, 88, 91, 182-3; symbolism, 165-6, 208; see also compulsory acquisition of land, land dealings

Anakale land case (Niue), 79-80

appeals, 123,130

Arnhem Land, 88

Asaro Valley, 117

Australia: (Federai) Government, 89, $163,164,168,184$; High Court of, 148; National Capital Development Commission, 175, 180; Supreme Court of Northern Territory, 88-9

\section{Baining, 167}

Baiyer-Kompiam, 126-33

banks, see International Bank for Reconstruction and Development, Papua New Guinea Development Bank

Barune, 171

Bele, Raphael, 185

Belgian Congo, 60

Bena, 143, 146

Bills, see Statutes, Ordinances, Bills

Bismarck Ranges, 135

Black, J. R., 143, 146

*Few people appreciate that compiling an index is not only frustrating but one of the most difficult parts of preparing a volume for publication-especially if a multitude of authors, each using his own terminology, discuss the same general problems from different points of view. I am therefore particularly grateful to Mrs A. H. Edwards for her help in carrying this bitter editorial burden. (Ed.) 
Blackburn, Mr Justice, 88, 89

Boas, O., 3

Bougainville, 118, 170, 176, 203; see also Bougainville copper project, mining

Bougainville Copper Agreement, 182, 194-9

Bougainville copper project, 181-99; see also mining

Bougainville Copper Pty Ltd, see Bougainville copper project

boundaries, 35-6, 109-10, 119-20, 127, 129-32, 135, 171, 202; in Kenya, 65, 67; in Niue, 85

British Solomon Islands Protectorate, Land and Title Ordinance 1968, 104

Buka Island, 118, 119, 203

Cape Hoskins, 167

Cargo Cult, 34, 55, 207

cash-cropping, 20-31, 49-61, 117.18, 143; indigenous attitudes to, 152, 204, 205; population pressure, 127, 131-2; transport facilities, 59, 118; see also tenure conversion

Champion, Ivan, 141

Chief Minister, see Somare, Michael Chimbu, 134-40, 141, 156-7

Choiseul Island, 204

clans, 116, 134-5, 172, 181-2; see also groups, lineages

Clan Land Usage Agreement, 107-14 colonialism, 2-3, 115, 156, 159-63, $165-7,169,177-89,203-8$

Commission of Inquiry into Land Matters, 2-4, 12-13, 63-4

Commissioner for Urban Development, 180

Committee Investigating Tribal Fighting in the Highlands, 13

communal rights, see clans, groups, lineages

compulsory acquisition of land, 60 , $171,176,181-2,184-9$ conquest of land, 126-7, 131-2, 135-7, $139,143,146-7,156,201$; see also 'fighting places', ownerless land consolidation, 73; in Kenya, 65-6, 689 ; see also fragmentation

constitution, 2, 7

Constitutional Development Committee, 46

Consultative Committees, 175

conversion, see tenure conversion

Conzinc Rio Tinto of Australia, 190, 196; see also Bougainville copper project

Cook Islands, 75, 82

court cases: Geita Sebea, 148; Yabilibiga, 148; Anakale (Niue), 79. 80; Gove (Australia), 88

cultural revolution, 6

custom, see tradition

Daru, 35

decentralisation, 12, 13, 49

demarcation, 72, 108, 129; see also Land Demarcation Committee

descent groups, see clans, groups, lineages

development, see agricultural development, economic development, industrial development

Development Bank, see Papua New Guinea Development Bank

development plans, 1, 16-31; aims, 2, 168, 190; local expertise, 193, 1945; psychological factors, 36, 117; technological and topographical factors, 58-60; use of traditional institutions, 115-16, 120-1, 125; see also economic development, 'Improvement Programme' of Decerrber 1972

Discriminatory Practices Ordinance 1963, 37-8

disputes over customary land, 94-5, 122-5, 126-58; court proceedings, 
128, 142-3, 145-50, 156; economic development, 127-8, 131-2, 141-4; politics, 151, 154-5, 157; population pressure, 127-8, 131-2, 151, 152, 156; psychological factors, 36 ; settlement procedures, 71-2, 129-32, 137-49; traditional methods, 135.6 ; violence, $141-2,151-2,154-5$; in Kenya, 67, 68, 69; in Niue, 79-80; see also adjudication, alienation of land to Europeans, appeals, 'fighting places', Land Demarcation Committees, Land Titles Commission, ownerless land, squatters

District Administration, 60, 179-80; see also Administration, kiaps

District Advisory Councils, 137

District Commissioners' Conference 1958, 60

District Land Boards, 12

District Land Registries, 12

Downs, I., 143

Dumont, Rene, 73

Eastern Highlands, 141 ; see also Highlands

economic development: forms of, 17 $18,54,116-17,128,134$; indigenous attitudes, 42-8, 52-3, 117 . $18,128,152-3,190$; indigenous control, 21, 49; pace, 186; population increase, 50, 53, 59, 127; rate of growth, 17, 22-6, 28-9; value, 183,186 ; see also agricultural development, Bougainville copper project, cash-cropping, development plans, industrial development, mining, tenure conversion

education, 33, 44, 50,137, 153,158, 166,193

Endugwa, 136, 156, 157

Enga, 132-3

English law, 89, 90, 92, 93-4, 123, 150,159

erosion, 57, 59
Erskine, Commander, 87, 204

Espie, Frank, 190

European settlement, 8, 9, 170, 171-2, 202-3, 204, 205, 207

experts, 95-8, 99-100

'fighting places', 129, 134, 145; see also disputes over customary land, ownerless land

Fiji, 76, 82, 85

fiancial self-reliance, 190,197

Fleming, T. J., 11

fragmentation, $57,76,79,88,172$; see also consolidation

freehold, 141, 178

French Polynesia, 76

foreign investment, 183, 188, 190-9

\section{Gahuku-Gama, 144}

Gazelle Peninsula, 72, 160, 161, 162

Geita Sebea land case, 148

Gena, 154, 156, 157

Goava, S., 3, 4

Goroka, 139, 143, 170, 172

Gove land case (Australia), 88

government: see Administration, Australia: (Federal) Government, National Coalition Government

government anthropologists, 38

groups, 35-6; dependence of individuals on, 33, 40, 42-3, 117, 119; ownership of land, 15, 39, 41-4, 89, $90,121-2,171,181$; registration, $11-12,177-8$; in Kenya, 65, 71; in Niue, 75, 76-8, 79-80; see also clans, lineages, tenure conversion, tenure of land, traditional

Grove, Don, 1, 11; see also Land Bills 1971

Guam, 82

Hagen, see Mt Hagen

Highlands, 13, 15, 73, 107, 126-58, 167 
Hookey, J., 15

House of Assembly: attitude to Administration, $1-3$; to land reform, $3-4,11-12,61,139$; to mining and foreign investment, 194-5, 197

housing, standards, 30,174

Huli, 51

Ialibu, 146

'Improvement Programme' of Decem. ber 1972, 49

indefeasibility, 10,159.63; see also registration, Torrens system

Independence, 1-2, 5, 13, 151-8, 162, 164

individualism, see tenure conversion

industrial development, 181, 191; see also Bougainville copper project, economic development, foreign investment, mining

inheritance, $50,52,88,121-2$

International Bank for Reconstruction and Development, 111

Isabel Island, 204

Jiga, 157

Julius, Charles, 38

Kainantu, 146

Kamanegu, 156, 157

Kammaneku, 136

Karamui-Bomai, 137

Kenya, 46, 47, 51, 62-71, 73, 114; adjudication, 64-5, 66-70; consolidation, 65-6, 68.9; control of land dealings, 64, 70-1; landlessness, 66; litigation, 66-7; relevance for Papua New Guinea, 71-4; registration, 64, 69-70; Swynnerton Plan, 73; visit of Papua New Guinea working party, 11, 63

Kenya, Land Adjudication Act 1968, 64

Kenya, Land Consolidation Act 1968, 64
Kenya, Registered Land Act 1963 , 100,103

Ketowagi, 154, 155

kiaps, 130, 154, 183; see also Administration, District Administration

Kieta, 183

Kiki, Albert Maori, 4

Kikuyu, 67, 68

Kila Kila, 171

kinship, see clans, groups, lineages

Koke, 173

Kokopo, 56

Kompiam-Baiyer, see Baiyer-Kompiam

Konedobu, 184

Korobosea, 178

Kundiawa, 136, 156

Kurumugl, 152

Lae, $72,170,171,175$

land: social organisation, 40-57, 90, $125,185-6,200-2$; as security for loans, 45, 93.4, 107-13, 120; Euro. pean attitudes, $44,60,88,115$, 206-8; indigenous emotional attachment, 32-9, 88, 134; future demand, $16.31,54,127,170$; indigenous attitudes, 8-9, 15, 151-2, 167, 181.2, 184; in Australia, 88; in Kenya, 70; see also economic. development, groups, tenure of land, traditional

Land Bills 1971, 1-2, 11, 46, 60-1, $63,100,103,149$

land dealings, 34-5, 94, 126-7, 144, 167, 177; in Kenya, 66-7, 70-1; in Niue, 83; see also alienation of land to Europeans

Land Demarcation Committees, 128 30,154 ; see also demarcation

land disputes, see disputes over customary land

land law, see Law, Statutes, Ordinances, Bills 
Land Ordinance 1962,144, 176 land ownership, see ownership land policy, 1, 11-12, 13-14, 43, 58, $60,62,75-6,116-17,182$; see also Administration, alienation of land to Eutopeans, development plans, economic development, urban development

land reforms, 132-3, 137-8, 140, 14950 ; see also resettlement, tenure conversion

land registration, see registration

Land Registration (Communally Owned Land) Ordinance 1963, 11. 12

land rights, see rights to land

land tenure, see tenure of land

Land (Tenure Conversion) Ordinance $1963,11,15,62,88,91,118,177$

land titles, see title to land

Land Titles Commission, 10-11, 13, 62-3, 129-31, 141-50, 154; see also disputes over customary land

Land Titles Commission Ordinance 1951-1966, 160

land use, see use of land

Lapun, Paul, 185

law, 87-96, 147-50; and customary attitudes, 46-7, 87-90, 129-30, 149; and social change, 37-8, 90-1, 115, 125, 153; and social factors, 38-9, 47-8, 50-1, 90-1, 94; and politics, $1-7,13-14,86,90-1,94,153-6$, 168, 176; see also English law, residual law, Statutes, Ordinances, Bills, Torrens system, traditional law, Western concepts

Laws Repeal and Adopting Ordinance 1921,87

Leahy brothers, 139

Leahy, Mick, 145, 146

leasehold: conversion of freehold, 1415 ; in urban areas, $72,173,176-80$; reversion to original owners, $14-15$; in England, 92; in Kenya, 65; in Niue, $82-4$

Legislative Council, 11

lineages, 35, 116, 120-2, 124; see also clans, groups

linguistic problems, 9-10, 109, 148, 155

litigation, see disputes over customary land

local government, 173

Local Government Councils, 49, 55-6, $60,138,153$

McCubbery, C. P., 148, 149

McGregor, Sir William, 204

Madang, 72, 170, 171, 175

Malawi, Registered Land Act 1967, 104

Manus Island, 119

Maori experience, 12

marketing, 59, 118-19

Marist Mission, 119

Melanesian, see tradition

mental disorders, $32-9$

Mental Disorders and Treatment Ordinance 1960,38

migration, $10,30,135,201-3$; to urban areas, $18-19,30,44,153$, $170,173-4$; see also resettlement, squatters

mining, 20, 181-99, 204; see also economic development, industrial development

Mining (Bougainville Copper Agreement) Ordinance $1967,182,196-9$

mixed race, 33

Morobe District, 34

Mt Hagen, 137, 139, 143, 146, 151 , 157

\section{Naregu, 157}

Naruku, 136

Nasioi, 182, 192, 193

National Capital Development Commission (Australia), 175, 180 
National Coalition Government, 3, $12,49-50,61,155$

nationalism, 3,49,94,120,150,182

Native Customs (Recognition) Ordinance $1963,37-8,87,94,124$

native institutions, see traditional customs and institutions

native land, 147.9

Native Lands Commission, 10, 14, 141

Neu Guinea Kompagnie, 204

New Britain, 51, 137

New Ireland, 72

Niue: control of land dealings 83 ; descent groups, 76-8, membership, 78-81; leadership, 81-2; government land, 84 ; land as security, 84 ; leases, 83-4; occupation rights, 82 3 ; registration and costs, $85-6$

Niue Land Ordinance 1902, 75-6

Niue Land Ordinance $1969,76,85$ 'no man's land', see ownerless land Northern District, 11, 62

occupation of land, $10,123,126,171$; in Kenya, 66; in Niue, 80, 82-3; relevant time for claims to ownership, 13, 123-4, 139-40,147, 148-9 occupation rights, in Niue, 82-3

Ordinances, see Statutes, Ordinances, Bills

Ordinances Interpretation Ordinance 1949-1964, 148

ownerless land, 14, 89, 103,129, 159, 171 ; see also 'fighting places'

ownership, 147-9; absolute, 15; individual, 116; traditional, 9-10, 41, $43,47,72-3,87-9,182-3$; ultimate, $38-9,89,149$; see also rights to land, tenure of land, tenure conversion

Pangu Party, 12

Panguna, 182
Papua New Guinea Development Bank, 107-14

Pari, 171

planters, 205, 206-7

police, 155,156

population increase, 18-19, 127, 131, $132-3,137,206$; and the traditional way of life, 49, 53-4, 59; control of, 17,153 ; expatriates, 8 ; in towns, $19-20,170,173$

Port Moresby, 8, 167, 170-80 prices and incomes policy, 17, 49 productivity, 19, 20-1, 23, 26, 43, 54 psychological attitudes: to land, 32 9, 50-1, 182-3; to development, 54-5, 183, 186

Purari Delta, 171

\section{Rabaul, 170, 175}

Registered Land Bill 1971, 136

registration, $1,12-13,72-3,161$; of groups, 11, 92, 177-8; of urban land, 72-3; in Kenya, 63, 64, 6970 ; in Niue, 85-6; see also tenure conversion

rights to land: communal, $41,75-6$, $148,171,172$; individual, 35,52 , $53,73,75-6,148,171,172$; 'primary' and 'secondary', 122, 171; see also groups, ownership, tenure of land, usuf ruct

resettlement, 29, 39, 116-17, 119-20, $132-3,137-8$

residual law, 100-1, 102-6

roads, 119

Rorovana, 182

Rowton Simpson, 63

rural development, see agricultural development

rural incomes, 17, 20-1, 23-6, 54, 152

Samoa, 204

Sepik River, 33, 143, 146

settlement schemes, see resettlement 
shell money, 40,56, 94

Shortland Islands, 204

Siambugla, 136

Sikou, 156, 157

Singga Valley, 152

social change, $32,33,40-61,112-13$, $152-4,158,185-6,192-3$; see also development, law and social change, tenure of land, traditional, changes in

social security, $44,53-4$

Solomon Islands, 204; see also British Solomon Islands Protectorate

Somare, Michael, 12, 49-50

squatters, $30,172,173-4$

Statutes, Ordinances, Bills: British

Solomon Islands Protectorate, Land and Title Ordinance 1968, 104; Kenya (Land Adjudication Act 1968) 64, (Land Consolidation Act 1968) 64, (Registered Land Act 1963) 100, 103; Malawi, Registered Land Act 1967, 104; Niue (Land Ordinance 1902) 75, (Land Ordinance 1969) 76; Papua New Guinea (Discriminatory Practices Ordinance 1963) 37, (Land Bills 1971) 1-2, 11, 46, 601, 63, 100, 103, 149, (Land (Tenure Conversion) Ordinance 1963) 11 , 15, 62, 88, 91, 118, 177, (Land Titles Commission Ordinance 1963) 142, 149, (Land Titles Restoration Ordinance 1951-1966) 160, (Land Ordinance 1962) 144, 176, (Land Registration (Communally Owned Land) Ordinance 1963) 11-12, (Laws Repeal and Adopting Ordinance 1921) 87, (Mental Disorders and Treatment Ordinance 1960) 38, (Mining (Bougainville Copper Agreement) Ordinance 1967) 182, 196-9, (Native Customs (Recognition) Ordinance 1963) 37-8, 87-94, 124,
(Ordinances Interpretation Ordinance 1949-1964) 148, (Registered Land Bill 1971) 103, (Town Planning and Development Bill 1969) 175, (Town Planning Ordinance 1952-1972) 175

Southern Highlands, 51, 52, 146; see also Highlands

subsistence agriculture, 26-7, 50, 57-8, 116 ; see also agriculture, traditional methods

Tahiti, 82

Tanzania, 12

Taurama, 171

Taylor, J. L., 139, 143, 144, 145, 146 taxation, 44, 94, 190-1, 195, 196, 197 tenure of land, traditional, 32, 35, $116,121-2,126-7,134-5,171,200$ 2 ; in Nive, 76-8; and loans, 45, 72, $93,107-14$; changes in, 15,172 ; future of, 54, 56-7, 87-96; see also agticulture, traditional methods of, groups, ownership, rights to land, tenure conversion, tradition

tenure conversion, $1,11,42-8,50-61$, $62-3,71-4,91,177-8$; in Kenya, $47,63-71$; in Niue, 78-86; in the Pacific, 75-6; see also resettlement, tenure of land, traditional, changes in

territorial imperative, 32-5

title to land, $10,46-7,148$; basic (radical), 38-9, 89, 149; see also ownership, registration, rights to land, tenure of land, Torrens system

Tolai, 51-6, 94, 116, 159-63, 167, 206

Tolai Cocoa Project, 54

Torrens system, 100, 101-3, 105, 162; see also indefeasibility, registration, title to land

town councils, 174-5, 177, 180; see also urban development 
town planning, $175-6$

Town Planning and Development Bill 1969,175

'Town Planning Board, 175

Town Planning Ordinance 1952-1972, 175

towns, see urban development

tradition, 50-1; 'bogus' 13; 'instant' 20 ; oral, $126,128-9,130-1,201$, $203-4$

traditional customs and institutions, $2,3-5,44,115,124-5,172$; obligations, $40-1,53,117,171,172$; values, 49-50, 182, 190, 207; see also agriculture, traditional methods of, rights to land, tenure of land, tradition

transport, 29, 59, 119

tribalism, 120

tribe, see clans, groups, lineages

'Trobriand Islands, 35 urban development, 8, 18-20, 30-1, 72 $3,170-80$

Urekit, K, 1

usuftuct, 52, 73, 107, 148; see also occupation rights, rights to land

Vial, L., 142

Wabag, 133, 141, 148

Wahgi, 133, 135

Ward, Alan, 12

Watagenga, 132-3

Waugla, 136

Western concepts, 3-5, 39, 87-96, 99$103,115,117,182-3,202,206-7$

Western Highlands, 141; see also Highlands

Yahilibiga land case, 148-9

Yamuga, 157 